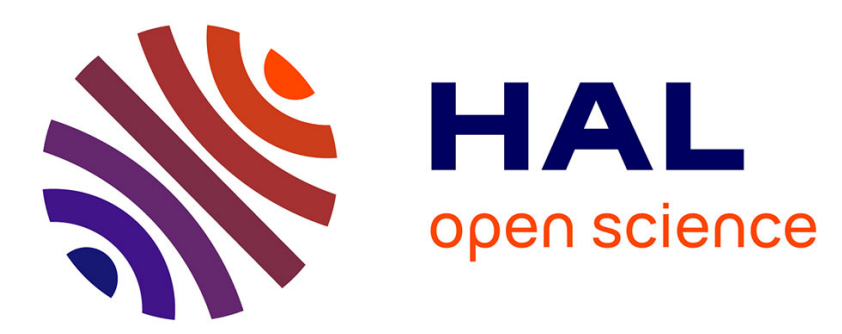

\title{
Climate sensitivity and geomorphological response of cirque glaciers from the late glacial to the Holocene
} David Palacios, Marc Oliva, Antonio Gómez-Ortiz, Nuria Andrés, José Fernández-Fernández, Irene Schimmelpfennig, Laëtitia Léanni

\section{- To cite this version:}

David Palacios, Marc Oliva, Antonio Gómez-Ortiz, Nuria Andrés, José Fernández-Fernández, et al.. Climate sensitivity and geomorphological response of cirque glaciers from the late glacial to the Holocene. Quaternary Science Reviews, 2020, 248, pp.1-26. 10.1016/j.quascirev.2020.106617. hal-02961582

\section{HAL Id: hal-02961582 \\ https://hal.science/hal-02961582}

Submitted on 1 Dec 2020

HAL is a multi-disciplinary open access archive for the deposit and dissemination of scientific research documents, whether they are published or not. The documents may come from teaching and research institutions in France or abroad, or from public or private research centers.
L'archive ouverte pluridisciplinaire HAL, est destinée au dépôt et à la diffusion de documents scientifiques de niveau recherche, publiés ou non, émanant des établissements d'enseignement et de recherche français ou étrangers, des laboratoires publics ou privés. 
4 David Palacios ${ }^{\mathrm{a}^{*}}$, Marc Oliva ${ }^{\mathrm{b}}$, Antonio Gómez-Ortiz ${ }^{\mathrm{b}}$, Nuria Andrés ${ }^{\mathrm{a}}$, José M.

5 Fernández-Fernández ${ }^{\mathrm{c}}$, Irene Schimmelpfennig ${ }^{\mathrm{d}}$ Laëtitia Léanni $^{\mathrm{d}}$, ASTER Team $^{\mathrm{d}}$ e

6

\section{Climate sensitivity and geomorphological response of cirque glaciers from the Late Glacial to the Holocene}

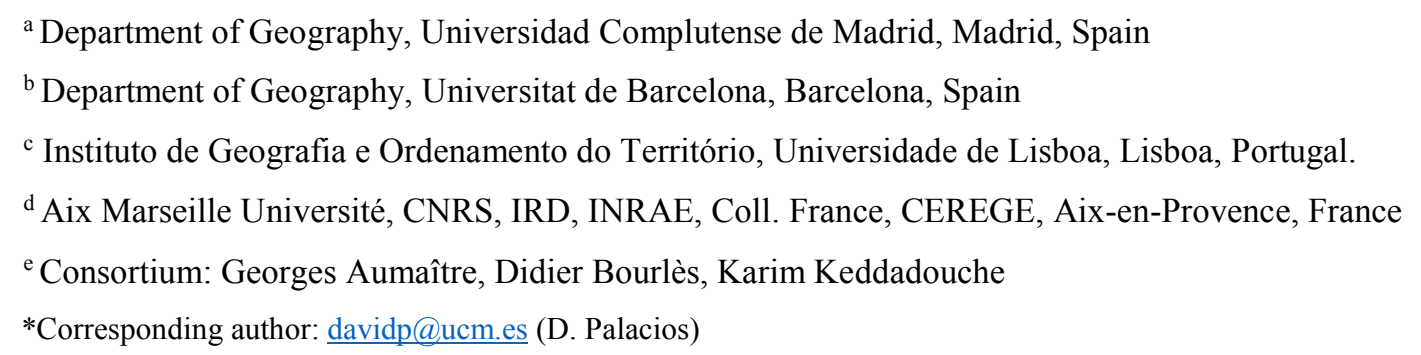

\section{Abstract}

Through a detailed geomorphological study, including thourough mapping of the geomorphic features as well as ${ }^{10} \mathrm{Be}$ Cosmic-Ray Exposure (CRE) dating, the geomorphological evolution of the Mulhacén cirque since the maximum ice extent of the last glacial cycle until nowadays was determined. This glacial cirque is shaped on the

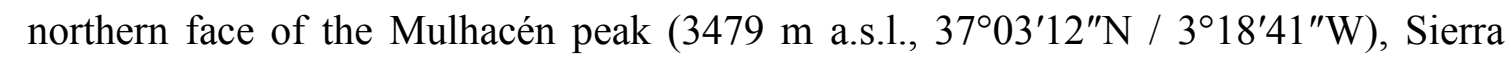
Nevada, southern Spain. It includes several depositional and erosional glacial landforms that allowed reconstructing its environmental evolution since the last glacial cycle. Furthermore, the sequence of glacial oscillations from this site was compared to that of other cirques of the massif, evidencing that: (i) new glaciers formed in these cirques during the Younger Dryas (YD), and (ii) disappeared at $11.7 \pm 1.0 \mathrm{ka}$. Depending on the altitude, orientation and height of the cirque walls, the final deglaciation of the cirques generated a diversity of landscapes, including a wide range of glacial and periglacial landforms, such as polished surfaces, sequences of moraines, proto-rock glaciers or large rock glacier systems. No glaciers existed in the Sierra Nevada during the Middle Holocene. Only the cirques whose summits exceed $3300 \mathrm{~m}$, are north-exposed and whose walls exceed $300 \mathrm{~m}$ high (i.e. Mulhacén and Veleta) hosted glaciers during Neoglacial phases, including the Little Ice Age (LIA) (approx. 1300-1850 CE). During these periods, climate oscillations favoured the formation of small glaciers in these cirques, which generated large moraine systems with either one polygenic ridge or a sequence of spaced frontal arcs. The existence of glaciers impeded the formation of permafrost-related 
landforms, such as rock glaciers and protalus lobes until the end of the LIA, when they started to form. These results are compared with the deglacial evolution in 55 cirques from Iberian mountains as well as from glacial cirques from other mid-latitude mountains and subpolar regions. The chronology of their deglaciation as well as the landforms generated during glacial retreat followed similar patterns, with no significant differences at regional scale. For each mountain range, the geomorphological diversity existing in each cirque depends on the local topographic characteristics although they formed during the same climatic phases.

Key words: Glacial Cirque, Rock Glacier, Sierra Nevada, Cosmic-Ray Exposure Dating, Late Glacial, Holocene.

\section{Introduction}

Glacial cirques are defined as armchair-shaped erosional hollows, typified by steep headwalls, typically arcuate and with lateral spurs, and with overdeepened floors, often occupied by a lake or bog (Evans and Cox, 1974, 1995; Barr and Spagnolo, 2015). The typology of cirques is extremely diversified and, therefore, the limits of this concept are difficult to define (Mîndrescu and Evans, 2014). Their origin is associated with the first steps of glaciation (Benn and Evans, 2010), although the mechanisms involved in their formation and upgrowth are still under debate (Sanders et al., 2012, 2013). Since the first studies, the importance of palaeoclimatic conditions driving the glacial and periglacial processes that shaped the heads of the valleys is highlighted (Benedict, 1973; Delmas et al., 2015; Barr et al., 2017). Consequently, several parameters such as the distribution, aspect, floor elevation and morphometry of the glacial cirques have been used to infer palaeotemperatures, precipitation gradients, cloud-cover and prevailing wind directions during glaciation (e.g. Dahl and Nesje, 1992; Barr and Spagnolo, 2015; Ipsen et al., 2018). However, other factors such as the geological structure, post-glacial erosion and the uncertainty regarding their origin make even more challenging to reconstruct past climate regimes using cirque morphometry (Barr and Spagnolo, 2015).

Moreover, it must be taken into account that enhanced by paraglacial dynamics, glacial cirques continue in many cases to evolve during the interglacial periods following the last phase of glaciation (Kleman and Stroeven, 1997; Ballantyne, 2002, 2013). This is especially important in the mountain ranges under Mediterranean influence, where glacial cirques are one of the most abundant glacial landforms, affected by the last glacial cycle 
and subsequent deglaciation (Hughes et al., 2006; 2007). Over recent decades, in

68 particular two palaeoenvironmental techniques, namely lake sediment record studies and

69 Cosmic-Ray Exposure (CRE) dating of glacial landforms using cosmogenic nuclides, have provided evidence of the potential palaeoclimatic information preserved in alpine cirques.

Many mountain glaciers reached their maximum extent between 26.5 and $19 \mathrm{ka}$ (Clark et al., 2009) or a few thousand years before (Hughes et al., 2013). This period is the socalled Last Glacial Maximum (LGM), which coincided with the minimum sea level at global scale (Clark et al., 2009; Hughes et al., 2013). However, this maximum extension was reached before or after the LGM in many other mountains, which is known as the Local Last Glacial Maximum (LLGM). In the Mediterranean region, particular attention has been paid to the reconstruction of the sequence of glacial phases recorded on cirque floors in the form of moraine systems revealing either (i) phases of stabilization during the long-term retreat since the LLGM, or (ii) short periods of glacial readvance. This is the case in the Rila mountains, Balkan Peninsula, where $2 \mathrm{~km}$-long cirques include a large number of moraines that formed between the LGM and the Younger Dryas (YD) (12.911.7 ka, Walker et al. 2009; GS-1 Rasmussen et al., 2014), i.e. within the approx. 24-12 ka period (Kuhlemann et al., 2013). One of the best examples of the geomorphological interest of these small glacial cirques comes from Mount Olympus, southern Balkan Peninsula, where moraines from the Late Glacial to the latest Neoglacial advances (from $15.6 \pm 2.0$ to $0.64 \pm 0.08 \mathrm{ka}$ ) are distributed over a distance of less than $500 \mathrm{~m}$ (Styllas et al., 2018). Similarly, in the Dinaric mountains, Žebre et al. (2019) summarized previous studies of numerous small cirques with a sequence of moraine systems dating back from Oldest Dryas (OD) to the YD (14.9 ka to $11.7 \mathrm{ka})$. Small cirques in the Apennines also retain geomorphic evidence in the form of moraine arcs formed between the LLGM and present-day (Giraudi, 2012; Baroni et al., 2018). There are many other examples of the potential of small cirques, including information about glacial oscillations occurred during Termination-1 (19 to $11.7 \mathrm{ka}$ ), such as in the Anatolian peninsula. Here, in Mount Geyikdag (Sarıkaya et al., 2017) and Mount Uludag (Zahno et al., 2010), ca. 1 km long cirques contain moraines from the LLGM to the Holocene. A similar pattern is found in small cirques of the High Atlas, Morocco, with moraine systems from different phases encompassing the entire deglaciation until the early Holocene (Hughes et al., 2019). 
99 Small glacial cirques with rich palaeoclimatic information are not exclusive of the

100 Mediterranean region. Cirques are also frequent glacial features in continental ranges as,

101 for example, those in Central Europe. Similar glacial chronologies as those described 102 above have been reported from cirques in the Krkonoše Mountains, Sudetes range (Engel 103 et al., 2014), or in cirques of larger formerly glaciated ranges, such as the Tatra 104 Mountains, Northern Carpathians (Engel et al., 2015; Makos et al., 2018; Zasadni et al., 105 2020), and Parang Mountains, Southern Carpathians (Gheorghiu et al, 2015), where 106 moraines from the OD to the Holocene have been dated. Small cirques in the Alps also 107 provided detailed information on glacial oscillations and the climatic evolution of the 108 Late Holocene (Ribolini et al., 2007; Ivy-Ochs et al., 2009; Hippolyte et al., 2009; Moran 109 et al., 2016; Ivy-Ochs, 2015; Le Roy et al., 2017). Well-known glacial oscillations from 110 the last glacial phases in many cirques of several mountain ranges of the Western United 111 States confirming previous results obtained in certain ranges such as the Sierra Nevada 112 (Clark and Gillespie, 1997) have been recently published (Marcott et al., 2019; Laabs et 113 al., 2020)

114 Glacial cirques in mountains that protruded from ice-sheet surfaces, such as those in 115 nunataks, also include geomorphic evidence of glacial fluctuations during the last glacial 116 cycle. This is the case of the Macgillycuddy's Reeks (South Ireland), where small cirques 117 host moraines from the LLGM and even younger (Barth et al., 2016). Moreover, glacial 118 cirques can also preserve accurate data on the last deglaciation phases of ice-sheets, as 119 well as on Neoglacial advances during the current interglacial. For example, up to four 120 glacial advances that occurred after the complete disappearance of the Scandinavian Ice121 sheet have been evidenced in numerous cirques in Norwegian mountains (Dahl and Nesje, 122 1992; Paasche et al., 2007). In Svalbard, small cirques contain moraines revealing that 123 the YD was only a minor advance, smaller than those of the Little Ice Age (from 1300 to 124 about 1850 CE, LIA) (Mangerud and Landvik, 2007). One of the best examples of the 125 palaeoclimatic significance of these cirques can be found in the Tröllaskagi Peninsula, 126 northern Iceland, formerly covered by the Icelandic Ice-Sheet (Ipsen et al., 2018). In this 127 peninsula, small cirques a few $\mathrm{km}$ long host up to 12 Holocene moraine complexes 128 corresponding to various stages of the LIA, and even different glacial advances over the 129 last decades (Fernández-Fernández et al., 2019). Moreover, other cirques in the 130 Tröllaskagi Peninsula include a set of erratic boulders, moraines, and several generations 
131 of rock glaciers and debris-covered glaciers showing a complex glacial evolution from the OD to the present (Tanarro et al., 2019; Fernández-Fernández et al., 2020).

133 In the Iberian Peninsula, small glacial cirques including several moraine systems have 134 been studied in the highest mountain ranges (Oliva et al., 2019). In the Eastern Pyrenees, 135 very small cirques preserve erratic boulders, complex moraine systems and rock glaciers 136 that reveal a complex glacial evolution from the LLGM to the Holocene (Pallàs et al., 137 2006, 2010; Delmas, 2015; Andrés et al, 2019; Jomelli et al., 2020). In the Central 138 Pyrenees, small cirques include moraine complexes from the OD to the Holocene 139 (Delmas, 2015; Palacios et al., 2017a; Crest et al., 2017; Tomkins et al., 2018), with only 140 a few sites recording Neoglacial advances (García-Ruiz et al., 2014). In the Cantabrian 141 Mountains, the heads of some cirques host rock glaciers and moraines from the OD to the 142 Early Holocene (Rodríguez-Rodríguez, 2016, 2017). In the Iberian Range, cirques < 1 $143 \mathrm{~km}$ long preserved moraines from the LLGM, OD and remnants of fossil debris-covered 144 glaciers, some of which were active until the Middle-Holocene due to their favourable orientation (Fernández-Fernández et al., 2017). Other cirques contain moraines from the

146 LLGM to the OD, when the formation of rock glaciers occurs, and even subsequent 147 deglaciated cirque steps, coetaneous with the YD (García-Ruiz et al., 2020a). In the 148 Central Range, small cirques in the massifs of Guadarrama (Palacios et al., 2011, 2012a, 149 2012b; Carrasco et al., 2016) and Gredos (Domínguez-Villar, 2013; Carrasco et al., 2013, 150 2015) include moraine complexes from the LLGM to the OD, YD and even the Holocene, 151 depending on the altitude and prevailing aspect of the cirques. Besides, a detailed study of the peatbogs from a glacial cirque in Gredos has provided valuable palaeoclimatic information from the deglaciation from the OD to the present (López-Sáez, et al., 2020).

154 The Sierra Nevada (South Iberia) contains 65 glacial cirques with geomorphic evidence 155 indicative of the glacial and palaeoclimatic evolution from the LLGM to the recent times 156 (Palacios et al., 2016; Palma et al., 2017) and, in some of these cirques, even from the 157 previous glacial cycle (Palacios et al., 2019). Regarding the Holocene, several 158 palaeoenvironmental archives such as lake records and peatbogs inside glacial cirques 159 testify to a remarkable climatic variability (Oliva, 2009; Oliva and Gómez-Ortiz, 2012), 160 as well as the impact of human activity (Anderson et al., 2011; García-Alix et al., 2013, 161 2017). Two of these cirques held also small glaciers during the LIA, which were the 162 southernmost in Europe (Gómez-Ortiz et al., 2009, 2015, 2018). One of them, the Veleta 163 cirque, shaped on the northern slope of the Veleta peak, contains valuable information on 
environmental dynamics from the first glacial phases of the LIA to the present-day, with evidence of: (i) the succession of several glacial advances and the gradual melting of the glacier, (ii) rock avalanches, (iii) landslides and, (iv) permafrost degradation. These processes, highly sensitive to small climatic variations, led to intense geomorphic readjustments typical of the paraglacial phase (Oliva et al., 2016; Palacios et al., 2019; Serrano et al., 2018; Gómez-Ortiz et al., 2019 and references therein). As a result, landforms from this cirque are considered key geoindicators for monitoring the impact of climate change on mountain geomorphological processes in southern Europe (GómezOrtiz et al., 2019). The other cirque that hosted a glacier during the LIA in the Sierra Nevada is located under the northern rock wall of Mulhacén peak. To date, although it contains a wide range of glacial depositional and erosional features, this cirque has been little studied. The only palaeoclimatic records from this cirque are those provided by the sediments of La Mosca Lake, which led to a detailed picture of the Mid-Late Holocene palaeoecological evolution as well as to the evidence of several glacial advances during the Late Holocene (Manzano et al., 2019; Oliva, 2009; Oliva et al., 2019).

179 On the other hand, the interpretation of the palaeoenvironmental records preserved in the interior of glacial cirques can come up against important difficulties, such as the alteration of glacial reliefs depending on the intensity of slope processes and the frequency of rock avalanches altering glacial landforms (Deline et al., 2015; Mercier et al., 2017; Knight et al., 2018) or the effects of neotectonic activity in cirque evolution (Oskin and Burbank, 2005). Regarding CRE dating, these processes can hinder the presumed undisturbed exposure of bedrock surfaces, rock glacier and moraine boulders to be dated, or potentially lead to nuclide inheritance in these surfaces (Li et al., 2016; Çiner et al., 2017; Köse et al., 2019),

Therefore, the current state of knowledge still presents some open questions, such as:

(i) What is the origin of the complex moraine formations frequently found inside the cirques and covering a wide chronological range?

(ii) Why do glaciers, once confined within the cirques, tend to evolve in many different ways, forming, in some cases, debris-covered glaciers or rock glaciers, and, in other cases, multiple moraine ridges developing in short periods of time? 
(iii) Is it possible to circumvent the impact of geomorphological processes occurring inside the glacial cirques to correctly extract the palaeoenvironmental significance preserved in their records?

197 In order to address these questions, the glacial landforms existing in one of the

198 Mediterranean cirques housing the most detailed sequence of the environmental evolution

199 since the LLGM, the Mulhacén cirque, have been analysed. To investigate the potential

200 common behaviour and infer its palaeoclimatic implications on different spatial scales,

201 the palaeoclimatic and geomorphologicalal evolution of this cirque is compared to that of

202 others in the whole massif of Sierra Nevada, the Iberian Peninsula and other mountains

203 of the Northern Hemisphere for which geomorphological and CRE data are available.

\section{2. Study area}

205 Located in the southern fringe of Iberia at latitude of $37^{\circ} \mathrm{N}$, the Sierra Nevada is the 206 highest massif of the Betic Range (Fig.1). It includes the highest peaks in western Europe 207 outside the Alps, with elevations exceeding $3000 \mathrm{~m}$ a.s.1. in its western fringe, such as

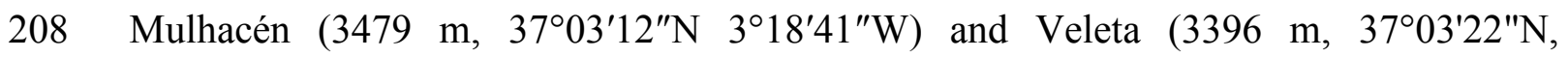
$\left.2093^{\circ} 21^{\prime} 56 " \mathrm{~W}\right)$. The landscape of the massif results from its bordering location between 210 different climatic influences: continental (Europe/Africa), maritime 211 (Atlantic/Mediterranean) and subtropical high pressure belt/mid-latitude westerlies

212 (Oliva et al., 2011). Currently, the mean annual air temperature at $2500 \mathrm{~m}$ is $4.4^{\circ} \mathrm{C}(1965$ -

213 1992), whereas at the highest summits of the massif at 3400 it is $0{ }^{\circ} \mathrm{C}(2001-2016)$

214 (Gómez-Ortiz et al., 2019). Annual precipitation reaches $710 \mathrm{~mm}$, mostly as snow 215 between October and April (Oliva, 2009; Oliva et al., 2008). The bedrock of the summit 216 area, the study site, is composed of micaschists which are intensely affected by periglacial 217 processes. The vegetation cover is very sparse, typical of the high semi-arid 218 Mediterranean mountains, and is mostly distributed across the valley floors near lakes 219 and wetlands (Oliva et al., 2011).

220 The contemporary landscape of the Sierra Nevada is mostly a consequence of past 221 glaciations. A wide range of depositional and erosional landforms of glacial origin are 222 distributed in elevations above 2000 (northern slopes) and $2500 \mathrm{~m}$ (southern slopes). 223 They result from the sequence of glacial phases that shaped the highest lands of the massif 224 since the maximum ice extent of the penultimate glacial cycle (Palacios et al., 2019). The 
LIA was the last period with the presence of glaciers in the Sierra Nevada (Gómez-Ortiz et al., 2009; 2012, 2015, 2018, Palacios et al., 2016).

227 The deglaciation of the cirques favoured the appearance of many mountain lakes and bogs 228 which have been sampled for palaeoenvironmental and palaeoclimatic purposes 229 (Anderson et al., 2011; García-Alix et al., 2013; 2017; Jiménez-Moreno and Anderson, 230 2012; Oliva et al., 2011, 2010). At the northern foot of the Mulhacén peak, a glacial lake 231 dammed by a moraine ridge is located next to the cirque mouth at $2892 \mathrm{~m}$ a.s.1.: the Mosca 232 Lake (ca. $90 \mathrm{~m}$ wide, $160 \mathrm{~m}$ long, 1 ha, $3.2 \mathrm{~m}$ deep) (Oliva and Gómez-Ortiz, 2012) (Fig. 233 1). A sequence of recessional moraines is connected to the large talus cones generated by 234 frost shattering from the steep northern rock wall of the Mulhacén peak, almost $400 \mathrm{~m}$ 235 high. These moraines show multiple collapses and subsidence features (Fig. 1) which 236 evidence the degradation of the small isolated permafrost patches still existing today in 237 the massif (Oliva et al., 2018; Serrano et al., 2018). The large talus cones are also being 238 affected by widespread debris flows transporting sediments downslope during the melting season or during extreme rainfall events in late summer and early autumn. At the foot of

240 the Mulhacén rock wall, there are a few semi-permanent snow-patches as well as a 241 protalus lobe formed following the final deglaciation of the cirque (Fig. 2), which is also 242 indicative of the existence of permafrost at this site (Serrano et al., 2018; Gómez-Ortiz et 243 al., 2019).

244 As revealed by historical documents and lacustrine sedimentary records, the cirque was 245 partly glaciated several times during the Holocene, namely at 2.8-2.7, 1.4-1.2 and 0.51$2460.24 \mathrm{ka}$ cal BP (Oliva and Gómez-Ortiz, 2012, Oliva et al., 2020). Lake sediment phases 247 recorded peaks with large concentrations of sand and very low organic carbon content, 248 which are attributed to colder and wetter conditions and the development of a glacier in 249 the catchment. The last of these periods coincided with the LIA, which promoted the 250 formation of the largest glacier over the three last millennia in the Mulhacén cirque (Oliva and Gómez-Ortiz, 2012). There are other longer sedimentary cores collected from this lake with radiocarbon dates up to $8.4 \mathrm{cal} \mathrm{ka} \mathrm{BP}$, which however do not come from the basal sediments, but give a minimum age of lake formation following glacial retreat

254 (Manzano et al., 2019). No chronological evidence is reported about earlier glacial 255 phases. Therefore, the moraines located upstream of the La Mosca Lake have probably 256 developed throughout the Holocene, whereas the moraines closing the lake must be older. 


\subsection{Geomorphological mapping}

259 In order to reconstruct the palaeoenvironmental evolution of the Mulhacén cirque since

260 the last glacial cycle, a detailed geomorphological analysis and mapping of the study area

261 was first performed. Although we consider the last glacial cycle as a synonymous of the

262 Late Pleistocene (approx. 123-14 ka; Hughes and Gibbard, 2018), most of the preserved

263 glacial landforms formed during the LGM or later. The different geomorphological units

264 were classified following the criteria used in previous studies of other glacial cirques in

265 this massif focusing on the distribution of moraines, rock glaciers, protalus lobes, rock

266 avalanches, debris flows and rock falls (Gómez-Ortiz et al., 2012; Palacios et al., 2016;

267 Palma et al, 2017). The spatial distribution of the different features of glacial origin

268 revealed in this cirque suggests a sequence of glacial events until the recent disappearance

269 of the LIA glacier. The geomorphological map was also used for planning the sampling

270 strategy for CRE dating in order to establish the chronology of the cirque deglaciation. In

271 addition, historical sources provided information concerning the periods during which

272 glaciers were present during the LIA in the Sierra Nevada (Gómez-Ortiz et al., 2009,

273 2012, 2015, 2018). These were also used to interpret the final deglaciation phases of the

274 Mulhacén cirque.

2753.2 CRE sampling strategy

276 The sampling strategy for CRE dating is based on the sequence of the mapped landforms,

277 from the bottom to the upper part of the cirque. In late summer 2016, when the cirque

278 was snow-free and geomorphic features were clearly visible in the field, eight samples

279 from the Mulhacén cirque at elevations between 2890 and $2950 \mathrm{~m}$ were collected. Two

280 of the samples were taken from glacially polished outcrops (MOSCA-2 and MOSCA-3),

281 while the others were taken from flat-topped surfaces of boulders located on moraine

282 ridges. The characteristics of the sampling sites and complementary field data are 283 summarized in Table 1.

\subsection{CRE laboratory procedures and exposure age calculation}

285 The samples were crushed and sieved to the $0.25-1 \mathrm{~mm}$ fraction at the 'Physical 286 Geography Laboratory' of the Universidad Complutense de Madrid. The following steps 287 of the sample preparation process were carried out at the 'Laboratoire National des 288 Nucléides Cosmogéniques' (LN2C) of the CEREGE (Centre Européen de Recherche et 289 d'Enseignement des Géosciences de l'Environnement, Aix-en-Provence, France). To 
extract the cosmogenic ${ }^{10} \mathrm{Be}$ isotope, a first rough isolation of the quartz mineral fraction

291 of the sieved samples was performed by means of a Frantz LB-1 magnetic separator removing the magnetic minerals. Subsequently, the remaining non-quartz minerals were dissolved through successive acid attacks (a mixture of concentrated hydrochloric $(\mathrm{HCl})$ and hexafluorosilicic $\left(\mathrm{H}_{2} \mathrm{SiF}_{6}\right)$ acids in a proportion 1:2). Three consecutive partial dissolutions using concentrated hydrofluoric acid (HF) were performed to ensure removal of any non-quartz mineral from the treated samples and to decontaminate the pure quartz mineral fraction from meteoric ${ }^{10} \mathrm{Be}$. For the following steps, pure quartz masses ranged between 6 and $40 \mathrm{~g} .150 \mu \mathrm{L}$ of an accurately weighted ${ }^{9}$ Be carrier solution manufactured in-house from a phenakite crystal $\left(\left[{ }^{9} \mathrm{Be}\right]=3025 \pm 9 \mu \mathrm{g} \mathrm{g}^{-1}\right.$; Merchel et al., 2008) were added, and the quartz was totally dissolved in $48 \% \mathrm{HF}(3.6 \mathrm{~mL}$ per g of quartz $+30 \mathrm{~mL}$ in excess). After the total dissolution, the resulting solution was evaporated until dryness and the solid residues were recovered in $7.1 \mathrm{M} \mathrm{HCl}$. Samples were precipitated with ammonia before successive separations, first through an anion exchange column (Dowex 1X8) to remove iron, and then through one or several cation exchange columns (Dowex 50WX8) to discard boron (isobar) and to separate the Be from other elements (Merchel and Herpers, 1999). All samples contained a lot of muscovite, which was difficult to remove completely and complicated the treatment of some of the samples. Therefore 17 cation exchange columns were performed for samples MOSCA-2, 3, 5 and 7.

309 The eluted Be was precipitated to beryllium hydroxide $\left(\mathrm{Be}(\mathrm{OH})_{2}\right)$ with ammonia and 310 oxidized to $\mathrm{BeO}$ at $700{ }^{\circ} \mathrm{C}$. As a final step, $\mathrm{BeO}$ were mixed with niobium powder in an 311 approximate 1:1 proportion, and then loaded in cathodes for the subsequent measurement 312 of the ${ }^{10} \mathrm{Be} /{ }^{9} \mathrm{Be}$ ratio at the ASTER ('Accélérateur pour les Sciences de la Terre, 313 Environnement et Risques') AMS (Accelerator Mass Spectrometry) national facility at

314 CEREGE. A chemical blank was prepared along with the seven samples.

315 Sample ${ }^{10} \mathrm{Be} /{ }^{9} \mathrm{Be}$ ratios were calibrated against the in-house standard STD-11, using an 316 assigned ${ }^{10} \mathrm{Be} /{ }^{9} \mathrm{Be}$ nominal ratio of $(1.191 \pm 0.013) \times 10^{-11}$ (Braucher et al., 2015).

317 Analytical $1 \sigma$ uncertainties include uncertainties associated with AMS counting statistics, 318 the standard ${ }^{10} \mathrm{Be} /{ }^{9} \mathrm{Be}$ ratio, an external AMS error of $0.5 \%$ (Arnold et al., 2010) and the 319 chemical blank measurement. A ${ }^{10}$ Be half-life of $(1.387 \pm 0.0012) \times 10^{6}$ years was used 320 (Chmeleff et al., 2010; Korschinek et al., 2010). More details of analytical data are given 321 in Table 1. 
$322{ }^{10} \mathrm{Be}$ surface CRE ages were calculated using the CREp online calculator (Martin et al., 323 2017; available online at: http://crep.crpg.cnrs-nancy.fr/\#/). The parameters used were: 324 the LSD elevation latitude scaling scheme (Lifton et al., 2014), the ERA40 atmospheric 325 model (Uppala et al., 2005) and the geomagnetic database based on the LSD framework 326 (Lifton et al., 2014). This setting yielded a sea-level high latitude (SLHL) ${ }^{10}$ Be production 327 rate of $3.98 \pm 0.22$ atoms $\mathrm{g}^{-1} \mathrm{yr}^{-1}$. Rock density was assumed to be $2.7 \mathrm{~g} \mathrm{~cm}^{-3}$. Partial 328 shielding of the surrounding topography from the cosmic-ray flux was calculated through 329 the Topographic Shielding Calculator v.2 of CRONUS-Earth Web Calculators (consulted 330 2020). CRE ages are reported for the zero denudation scenario, and uncertainties included 331 hereafter include analytical and production rate errors (Table 2).

332 The results of the analysis carried out in the Mulhacén cirque have been confronted with 333 previous studies involving $\mathrm{CRE}$ dating, some using ${ }^{10} \mathrm{Be}$ and others ${ }^{36} \mathrm{Cl}$, conducted in 334 other cirques of the Sierra Nevada and in the rest of the Iberian mountains. In order to 335 compare the results obtained from the two cosmogenic nuclides, all the CRE ages 336 mentioned in the text were recalculated in accordance with the protocols proposed for the 337 Iberian Peninsula in Oliva et al. (2019). Also, to compare our results with those obtained 338 in cirques from other mountains outside Iberian Peninsula where CRE dating was 339 performed, we have checked all the publications of the last five years that include a 340 detailed description of the CRE age calculation protocols and only those with similar 341 protocols to those applied to Iberian mountains were considered.

342 In addition, the information on the glacial chronological sequences provided by the new

343 CRE ages were compared with the palaeoenvironmental evidences previously inferred 344 from the sedimentary studies of La Mosca Lake (Oliva and Gómez-Ortiz, 2012; Manzano 345 et al., 2019) as well as from other lakes and peatbogs of the massif (Anderson et al., 2011; 346 García-Alix et al., 2013, 2017; Jiménez-Moreno and Anderson, 2012; Oliva et al., 2011, 347 2010).

\section{4. Results}

\subsection{Geomorphological setting and CRE sample selection}

350 The results of the geomorphological analysis of the Mulhacén cirque are summarized in 351 the geomorphological map (Fig. 2) as well as along a transect including the most remarkable glacial and periglacial features (Fig. 3). 
353 For CRE dating, we focused on rocky outcrops with glacially polished surfaces that 354 protrude above the bottom of the cirque and had probably not been covered with sediment 355 after deglaciation; however, few suitable sites were found as debris cover is very abundant 356 in the Mulhacén cirque floor. In addition, due to an efficient weathering of the micaschist 357 bedrock, the original glacial surface of the few outcrops standing in the cirque floor is 358 often not preserved and, therefore, only two polished surfaces were considered suitable 359 for CRE dating. One sample was taken from a bedrock step below La Mosca Lake 360 (MOSCA-2) and another one from a bedrock step above it (MOSCA-3) (Figs. 4 and 5).

361 The Mulhacén cirque ends downvalley in a large step that descends vertically from 2920 362 to $2600 \mathrm{~m}$ to the Valdecasillas gorge. The sample MOSCA-2 is located just on the edge 363 of this step, next to two moraine ridges damming the La Mosca Lake. Due to the highly 364 weathered surface of the rocks, only three boulders from these ridges appeared suitable 365 for CRE dating (not affected by denudation, and standing out above the cirque floor): one 366 from the outermost moraine (MOSCA-1) and two from the ridge closest to the lake 367 (MOSCA-6 and MOSCA-7). The quartz content in sample MOSCA-1 was too low for ${ }^{10} \mathrm{Be}$ extraction and was considered non-suitable for further analyses.

369 A bedrock step above the lake was sampled (MOSCA-3). Large boulders within fine370 grained matrix are distributed on this step. In contrast to the majority of moraines in the 371 Sierra Nevada, composed of abundant fine sediments due to the weathering of the 372 micaschists (Gómez-Ortiz et al, 2012; Palacios et al., 2016), this ridge preserved metric373 size boulders. However, most of them were intensely fractured by frost shattering after 374 their deposition, and only one sample from this landform was collected (MOSCA-5).

375 Overlapping this ridge, there is a moraine including both boulders and fine sediments. 376 One boulder from this ridge was sampled, whose surface showed glacial striations 377 ensuring that it has not undergone major degradation since its deposition (MOSCA-4).

378 Above this ridge, there is a large area with a massive accumulation of boulders that 379 corresponds to a large moraine system composed of several ridges. Due to the steep slope, 380 the shape of some of these ridges has been altered by rock falls and slope readjustment, 381 though they still show an arcuate morphology. All these moraines seem to be affected by 382 slow flow of the surface sediments towards the base of the cirque, likely due to the 383 presence of buried ice and permafrost patches such as those detected and monitored in 384 the neighbouring Veleta cirque (Gómez-Ortiz et al., 2015; 2019). There are several 
depressions of collapse and subsidence features (Fig. 2) related to the degradation of the

386 frozen mass located below the debris cover, which also affected the stability of the boulders. In addition, there are also abundant rocks fallen from the steep north wall of the Mulhacén, located only at less than $300 \mathrm{~m}$ from these deposits. Consequently, it was difficult to find boulders suitable for CRE dating and indicative of the age of stabilization of this moraine system. In fact, only one likely appropriate boulder in an external ridge was sampled (MOSCA-8).

392 According to historical sources (Gómez-Ortiz et al., 2009, 2015, 2018), the LIA glacier did not reach these outermost moraines and only occupied the innermost moraine systems closer to the northern Mulhacén rock wall, which is very active supplying debris to the talus cones. Currently, an active protalus lobe at the foot of the rock wall indicates the occurrence of permafrost conditions at this site.

\subsection{CRE results}

398 As usual, we highly recommend using only the internal (analytical) errors, when the ${ }^{10} \mathrm{Be}$ ages are compared amongst them (at the study site and at the other sites), because they are all equally impacted by the production rate uncertainty - the production rate uncertainty has to be considered when the ${ }^{10} \mathrm{Be}$ ages are compared to other chronological data.

The CRE results are presented in Table 2, and Figs. 6 and 7. The two samples from polished bedrock lead to indistinguishable CRE ages: $13.5 \pm 0.8 \mathrm{ka}$ (MOSCA-2) and 14.2 \pm 0.8 (MOSCA-3). Assuming that the age of the bedrock samples reveals the age of the final ice retreat in the mouth of the cirque, this leads to a mean CRE age of $13.8 \pm 0.8 \mathrm{ka}$ $(n=2)$.

408 The two samples from the moraine just below La Mosca Lake yielded to CRE ages of $40912.6 \pm 0.9 \mathrm{ka}$ (MOSCA-6) and $16.4 \pm 1.1 \mathrm{ka}$ (MOSCA-7). Therefore, although from the 410 same moraine, one boulder leads to an age $1.6 \mathrm{ka}$ younger than the age of the bedrock 411 surface where it rests, whereas the other leads to an age 2.2 ka older, respectively. 412 Considering that the exposure age of the sample MOSCA-7 is older than that of the 413 bedrock where it rests, it can be considered an outlier.

414 The samples taken above the lake - one located in a moraine of one of the lower ridges 415 (MOSCA-4, $9.8 \pm 0.8 \mathrm{ka}$ ) and the other in a moraine of one of the highest ridges 
416 (MOSCA-8, $10.2 \pm 0.7 \mathrm{ka}$ ) - lead to indistinguishable CRE ages whose mean value is

$417 \quad 10.0 \pm 0.7 \mathrm{ka}(\mathrm{n}=2)$. The deposition of these boulders resulted from different glacial

418 events separated by only a few hundred years. The sample taken from the ridge formed

419 by large boulders, located above the lake, leads to a CRE age of $23.4 \pm 1.5 \mathrm{ka}$ (MOSCA-

420 5). Significantly older than the landforms located more distant from the cirque wall (mean

421 CRE age of $14.1 \pm 0.9 \mathrm{ka}(\mathrm{n}=4))$, this age is inconsistent with the geomorphological

422 sequence, probably due to nuclide inheritance.

\section{5. Discussion}

424 The results obtained in this work provide an approximate chronology of glacial retreat in 425 the Mulhacén cirque, located at the foot of the highest peak in the Iberian Peninsula. The 426 scarce number of landforms suitable to be sampled for the application of CRE dating 427 impeded providing an accurate sequence of glacial oscillations for the transition from the 428 Late Glacial to the Early Holocene, when most of the cirque became ice-free. This is due 429 to the very intense geomorphological processes of the northern wall of the Mulhacén, 430 with intense rock fall activity generating large talus cones that have covered some of the 431 most recent moraines. In addition, the micaschist bedrock fractures very easily and it is 432 therefore very difficult to find original glacial surfaces in boulders or bedrock outcrops.

\section{3 \\ 5.1 Sequence of geomorphological phases in the Mulhacén cirque}

434 Despite the small number of available samples to which the CRE dating method can be applied with confidence, the combination of the results obtained in this study with those from previous studies points to the occurrence of a number of geomorphological phases inside the Mulhacén cirque (Table 2, and Fig. 6 and 7):

438 (i) The deglaciation of most of the cirque culminated approximately at $14 \mathrm{ka}$ - including 439 the area where La Mosca Lake is located -, which is related to the Bølling-Allerød 440 Interstadial (B-A; 14.6-12.9 ka; GI-1 Greenland ice cores; Rasmussen et al., 2014). These 441 results are compatible with the previous study that suggested that lake sedimentation 442 started before 8.4 cal ka BP (Manzano et al., 2019).

443 (ii) Other published works focusing on La Mosca Lake sediments reported glacial 444 oscillations during the Late Holocene. Three coarse-grained layers deposited in the lake 445 bottom were interpreted as indicating the existence of a glacier in the catchment at 2.8446 2.7, 1.4-1.2 and 0.51-0.24 ka cal BP (Oliva and Gómez-Ortiz, 2012). The presence of a 447 glacier during the LIA in this cirque was also confirmed by historical sources (Gómez- 
Ortiz et al., 2009, 2015, 2018). Our results show that the extent of these palaeoglaciers was spatially limited, with small features only located at the base of the wall in the concavities that are currently occupied by talus cones. According to our results, the last

451 Early Holocene glacial advance that generated moraines reached a distance of only 300 $\mathrm{m}$ from the foot of the wall.

453 (iii) The set of moraines located between the talus cones and the lake, with up to 6 different ridges in less than $400 \mathrm{~m}$, is indicative of repeated glacier advances and retreats in the early stages of the Holocene, towards ca. $10 \mathrm{ka}$. These Early Holocene glaciers had a significant debris cover provided by the northern rock wall of the Mulhacén cirque. Indeed, the abundance of boulders across this moraine system shows evidence of the very high debris supply on palaeoglaciers from the rock wall. During their retreat, the ice gradually melted leaving multiple collapse depressions.

460 The age difference between the samples that mark the deglaciation of the mouth of the cirque during the B-A Interstadial, and those of the moraines deposited at the bottom of the cirque during the Holocene, was also shown in a previous work (Oliva et al., 2015) by the application of Schmidt Hammer Exposure Dating, with higher rebound (R values) indicative of less weathered surfaces and thus younger ages. The moraine that led to a ${ }^{10} \mathrm{Be} C R E$ age of 14 ka coincided with an $\mathrm{R}$ value of $55 \pm 4$, whereas the $\mathrm{R}$ values in the $10 \mathrm{ka}$ ridge were higher, $64 \pm 6$ (Oliva et al., 2015).

(iv) There are some samples that show evidence of cosmogenic nuclide inheritance. In fact, the outlier sample MOSCA-5 is related to the unique moraine formed by large boulders with no fine-grained sediments. The overestimated exposure age may be related to boulders fallen from the wall and transported supraglacially on the ice surface with no or very little surface readjustment. This process has earlier been inferred in other mountain cirques, especially in small ones with limited distance between the headwall and the moraines (Li et al. 2016; Çiner et al, 2017; Köse et al., 2019).

474 (v) According to our results, there is no evidence of glacial activity during the Holocene 475 Thermal Maximum (HTM: 9-5 ka, Renssen et al., 2009) in this cirque.

476 (vi) The current intense geomorphological activity of the rock wall is shown by the 477 formation of large rock fall cones and talus since the disappearance of the LIA glacier. 478 These rock fall cones are underlain by permafrost, as it is demonstrated by the recent 479 development of a protalus lobe at the foot of such rock wall (Serrano et al., 2018). 

their palaeoclimatic and topographic significance.

482 In the Sierra Nevada, there is remnant evidence of two Late Pleistocene glacial cycles 483 that are preserved in the form of moraine complexes in the southern valleys of the massif. 484 During the last glacial cycle, the maximum ice extent slightly predated the LGM, as it has 485 been shown by CRE dating of boulders from lateral moraines from the largest glacial 486 valleys (Gómez-Ortiz et al., 2012; 2015; Palacios et al., 2016; 2019; Oliva et al., 2019). 487 Moreover, the sequence of glacial phases inferred from several other cirques in the Sierra 488 Nevada (Gómez-Ortiz et al., 2012; 2015; Palacios et al., 2016; 2019; Oliva et al., 2019) 489 show a similar sequence of the last deglaciation to the one presented here from the 490 Mulhacén cirque, whose main phases have been summarized in Table 3. It is important 491 to consider that glacial cirques do not always form at the head of the valleys, such as in 492 the Sierra Nevada where many develop on lateral slopes of the main valley more 493 favourable for snow accumulation, especially on E- or NE-facing slopes.

494 Several common spatio-temporal patterns can be inferred with regards to the deglaciation 495 evolution in cirques of the Sierra Nevada (Table 3 and Fig. 7):

496 (i) All the cirques studied in the Sierra Nevada were deglaciated at the beginning of the 497 B-A, although glaciers either remained as small features or regenerated during the 498 following cold phases. Six of the eight cirques studied Sierra Nevada show 499 indistinguishable deglaciation ages based on samples obtained from polished bedrock 500 surfaces, with an average of $14.0 \pm 1.2 \mathrm{ka}(\mathrm{n}=6)$ (samples from Palacios et al., 2016 and 501 present work) (Fig. 7 and 8A). Therefore, these datasets suggest that shortly after the 502 onset of the B-A the valley floors were ice-free and glaciers were confined within the 503 cirques as small features at the foot of the highest rock walls and probably disappeared 504 from many others (Fig. 8B and C).

505 (ii) There are only two cirques (Río Seco and Caldereta) including samples of polished 506 bedrock surfaces that suggest a more recent deglaciation (12.0 $\pm 1.1 \mathrm{ka}, \mathrm{n}=3$ ) (Palacios 507 et al., 2016). They do not preserve evidence of later moraine formations or the 508 development of large rock glaciers. These younger ages would reveal the presence of 509 glaciers after the main deglaciation at the bottom of the cirque, as in other cirques, but 510 they did not generate moraines or rock glaciers when the ice melted, most likely due to 511 the low debris supply from relatively stable rock walls. 
512 (iii) In most cases, after the most important deglaciation phase following the LLGM,

513 glaciers persisted in the cirques, or they regenerated during the YD (Fig. 8.D). Some inner

514 moraines in the cirques have a stabilization age similar (considering their uncertainties)

515 to polished bedrock surfaces, with an average age of $11.4 \pm 1.0 \mathrm{ka}(\mathrm{n}=6)$ (Palacios et al.,

5162016 and present work).

517 (iv) The importance of topographical constraints controlling the geomorphological 518 evolution in each cirque of the Sierra Nevada after its final deglaciation at the end of the

519 YD. Moreover, the topographical conditions of each cirque favoured the generation of 520 different type of landforms:

521 a) The cirques with summit altitudes $>3300 \mathrm{~m}$ and floors $>2950 \mathrm{~m}$, north exposed and with cirque walls $>300 \mathrm{~m}$ high were the most climatically sensitive considering the geomorphological setting. They include evidence of glacier changes from the YD to the present. This is the case of the Veleta and Mulhacén cirques. But it is noteworthy that each one evolved differently: in the case of the Veleta cirque, a large polygenic moraine was formed (Gómez-Ortiz et al., 2009; 2012, 2015; Palacios et al., 2019) (Fig. 8E.4), whereas in the Mulhacén cirque a sequence of moraine ridges developed (Fig. 8E.5). During the HTM glaciers probably melted away in these cirques, but regenerated under the cold Neoglacial conditions prevailing during the Late Holocene, namely during the LIA (Gómez-Ortiz et al., 2009; 2012, 2015, 2018 ; Oliva and Gómez-Ortiz, 2012; Palacios et al., 2016). These Neoglacial advances enlarged the polygenic moraine in the Veleta cirque, and must have generated new moraine ridges in the Mulhacén cirque. However, the very intense geomorphological processes of the Mulhacén wall accumulating large masses of debris at the foot of the steep slope of the cirque and the readjustment of the moraine boulders have hidden the associated evidence.

b) Cirques with summit altitudes between 3000 and $3200 \mathrm{~m}$, floors located above $2800 \mathrm{~m}$, with small headwalls (elevation range $<200 \mathrm{~m}$ ) and east-facing produced only small proto-rock glaciers. This is the case of the Peñón Colorado, Río Seco and Caldereta cirques. In these cirques, where proto-rock glaciers developed, their fronts stabilized shortly after they formed (Fig. 8E.1).

c) In cirques with summit altitudes $<3000 \mathrm{~m}$ and floors below $2800 \mathrm{~m}$, the retreating glaciers left one or more moraines - or even none - depending on the intensity of the 
paraglacial readjustment of their walls rather than the climate oscillations, and no rock glaciers formed. This is the case of the Hoya de la Mora, Mojón de Trigo and Moro cirques (Fig. 8.E.3). These moraines are located between 400-700 $\mathrm{m}$ away from the cirque walls, showing evidence of the small size of the YD glaciers.

548 (v) Except in the case of the Veleta and Mulhacén cirques, the landscape of the rest of the 549 cirques is similar to that existing during the HTM. No new glacial landforms have formed 550 since and they have been affected only by limited periglacial and slope processes during 551 Late Holocene cold phases (Oliva, 2009; Oliva and Gómez-Ortiz, 2012; Oliva et al., 2010; 2011 and 2020).

553 (vi) Based on the evolution and chronology of the Sierra Nevada glacial cirques, we 554 assume that the origin of the rock glaciers they host are related to the process of 555 deglaciation that occurred at the beginning of warm periods in connection with 556 paraglacial processes which triggered an intense geomorphological activity of the rock walls (Kleman and Stroeven, 1997; Ballantyne, 2002; 2013, Knight et al., 2018; Serrano et al., 2018).

559 (vii) As in other cirques of the Sierra Nevada at the end of the Late Pleistocene glacial 560 phases, the end of Neoglaciation with the disappearance of the LIA glaciers has favoured 561 the development of a small rock glacier in the Veleta cirque (Gómez-Ortiz et al., 2015; 2019) and a protalus lobe in the Mulhacén cirque (Serrano et al., 2018), where small isolated permafrost patches exist under the debris cover (Oliva et al., 2018; Serrano et al., 2018). These landforms are geoindicators of the end of cold periods and are out of balance with current climate conditions, and therefore, tend to become inactive (Oliva et al., 2018; Gómez-Ortiz et al., 2019).

\subsection{The typology of the cirques in Sierra Nevada in the context of the Iberian Peninsula}

Studies similar to those conducted in the Sierra Nevada have been carried out in other Iberian mountain ranges, although most of them focused on individual cirques, with the exception of some studies in the Pyrenees. The chronology of formation of different

571 landforms in the cirques of the Sierra Nevada is highly similar to the periods of formation 572 of analogous geomorphological features in other Iberian cirques (Table 4).

573 (i) Based on the available literature, we have analyzed a total of 26 Iberian cirques, where 574 the maximum and minimum CRE ages of deglaciation at their mouth vary from $16.3 \pm$ 
$5753.3 \mathrm{ka}$ to $13.2 \pm 0.7 \mathrm{ka}$, considering either the time of stabilization of external moraines,

576 or the outcropping of the bedrock due to the disappearance of the ice (Table 4). The 577 average age of deglaciation taking into account all these cirques is $15.1 \pm 1.3 \mathrm{ka}(\mathrm{n}=21)$

578 (Table 4 and Fig.9.A). According to marine and terrestrial records from the Iberian 579 Peninsula and surrounding areas (Fletcher et al., 2010a, 2010b, Moreno et al, 2014; 580 López-Sáez, et al., 2020), a sudden temperature increase that led to values similar to 581 present is recorded at the beginning of B-A. The accelerated deglaciation of the cirques 582 probably during the B-A has been detected in many other cirques in Iberian mountains 583 (Palacios et al., 2017b), such as the Central Range (Palacios et al., 2011; Palacios et al., 584 2012a, 2012b; Carrasco et al., 2015), Iberian Range (Fernández-Fernández et al., 2017; 585 García-Ruiz et al., 2020a), Central Cantabrian Mountains (Rodríguez-Rodríguez et al., 586 2017) and the Pyrenees (Pallàs et al., 2006, 2010; Delmas, 2015; Palacios et al., 2017a; 587 Crest et al., 2017; Tomkins et al., 2018; Andrés et al, 2019; Jomelli et al., 2020).

588 (ii) Although they still need to be studied in much more detail, YD glaciers existed within 589 the cirques of other Iberian mountain ranges (García-Ruiz et al., 2016). There are few studies on YD related moraines in the in the Pyrenees (Pallàs et al., 2006; Crest et al., 2017; Palacios et al., 2017a; Andrés et al., 2019) and one in the Central Range (Carrasco et al., 2015). However, dating of bedrock surfaces in nine other cirques shows that glaciers occupied the bottom of the cirques until the beginning of the Holocene (Palacios et al., 2011, 2012b, 2017a; García-Ruiz et al., 2020a; Crest et al., 2017 Andrés et al., 2019; Jomelli et al., 2020). Although the age of the bedrock surfaces and the moraines resting on them suggest the occurrence of different glacial phases, in this global analysis the mean of the two types of ages can be interpreted as indicative of the final ice disappearance from the cirques. The average age of the deglaciation of all these cirques is $11.2 \mathrm{ka}(\mathrm{n}=17)$, which fits within the onset of the Holocene, once temperatures 600 increased following the YD (Table 4 and Fig.9.A). In the rest of the cirques, there is a 601 lack of information on the glacial impact of the YD due to lack of dating or because the 602 bottoms are still occupied by rock glaciers. According to the 9 cirques with dated 603 moraines, the glaciers in the YD never exceeded the limits of the cirque, with lengths between 500 and $1200 \mathrm{~m}$ (Table 4). The abrupt warming after the YD cold period is evidenced in marine and terrestrial records of the regional Iberian context (Fletcher et al., 
607 (iii) In some cases, boulder exposure ages from the front of the rock glaciers are provided.

608 It is assumed that these ages represent the melting of the interstitial ice, i.e. the 609 stabilization of the rock glacier fronts (Zasadni et al., 2020). In six cirques, rock glaciers

610 likely stabilized somewhat before or at the start of the B-A Interstadial (Rodríguez611 Rodríguez et al., 2016, 2017; Andrés et al, 2019; García-Ruiz et al., 2020a), but the roots 612 of the large rock glacier complexes stabilized during the Middle to Late Holocene 613 (Palacios et al., 2017a; Andrés et al, 2019; Jomelli et al., 2020). The stabilization periods 614 (onset, duration and ending) of two debris-covered glaciers from the Iberian Range were 615 determined by the aspect, and hence by solar radiation. They range from the beginning of 616 the B-A to the Middle Holocene (Fernández-Fernández et al., 2017) (Table 4).

617 (iv) Neoglacial landforms are located in cirque floors only at the foot of the northern face 618 of peaks above $3000 \mathrm{~m}$ in the Central Pyrenees (García-Ruiz et al., 2014; 2020b).

619 (v) In summary, in all highest Iberian mountains geomorphological features similar to 620 those in the Sierra Nevada cirques have been observed, regarding both type and 621 development period. The deglaciation of the cirques started at the beginning of the B-A 622 and new glaciers developed during the YD. Following the glacial retreat at the onset of 623 the B-A, as well as during the Early Holocene, shrinking glaciers triggered the formation 624 of rock glaciers in areas of high sediment supply (e.g. at the foot of steep rock walls), 625 with their fronts stabilizing shortly after forming. The sediment supply of the cirques 626 depends on the rock types (see Table 4), but also on the persistence of weathered substrate 627 of the cirque rock wall, especially in granitic areas (Palacios et al., 2017a; Andrés et al., 628 2019).

6295.4 Diversity of landforms associated with cirque deglaciation in the Northern 630 Hemisphere

631 In order to explore if the geomorphological evolution within glacial cirques in the Sierra 632 Nevada and other Iberian ranges represents a local or a more widespread climatic pattern, 633 we have examined dozens of glacial cirques in the Northern Hemisphere where CRE data 634 are available. To this end, we have analysed chronological data from cirques from the 635 Mediterranean region, Central Europe, the British Isles and subpolar regions. We have 636 also included the analysis of numerous cirques in the western United States where precise 637 chronologies are available (Marcott et al., 2019). 
638 (i) Located between 31 and $37^{\circ} \mathrm{N}, 11$ Mediterranean cirques from the Anatolian and 639 Balkan peninsulas and north Morocco benefitting from new detailed CRE chronology 640 were analysed (Table 5). Eight of the 11 cirques include chronological data on their initial 641 deglaciation. All of them became ice-free at an averaged CRE age of 14.1 $\pm 1.4 \mathrm{ka}(\mathrm{n}=8)$, 642 in consistency with the findings from Iberia (Table 5, Fig. 9.B) (Köse et al., 2019; 643 Sarıkaya et al., 2017; Styllas et al., 2018; Hughes et al., 2018; Žebre et al., 2019). Seven 644 cirques include moraine ridges inside the cirques, five of which formed during the YD 645 (Köse et al., 2019; Sarıkaya et al., 2017; Styllas et al., 2018; Hughes et al., 2018; Žebre 646 et al., 2019). Only a few limestone cirques in the Anatolian peninsula reported 647 significantly younger moraine ages (Sarikaya et al., 2017). With the exception of these 648 excluded cases, the average CRE age of these moraines is $12.0 \pm 0.8 \mathrm{ka}(\mathrm{n}=8)$ (Table 5, 649 Fig. 9.B) and the glacier lengths ranged from 700 to $2500 \mathrm{~m}$. There are only some CRE650 dated rock glaciers in this region. Evidencing cosmogenic nuclide inheritance, they were 651 not included in our analysis (Çiner et al, 2017). Neoglacial landforms appear only in 652 cirques with peaks near $3000 \mathrm{~m}$ (Styllas et al., 2018), with the exception of Anatolia 653 (Sar1kaya et al., 2017).

654 (ii) 17 cirques from Central Europe mountains located between $45^{\circ}$ and $50^{\circ} \mathrm{N}$ were 655 analysed (Table 6). Most of them are situated in the Carpathian Mountains, only two 656 being low-altitude cirques from the Alps. In the Central Alps, the YD glaciers were 657 beyond the cirque area and, hence, they are not considered in our analysis. Up to 15 658 cirques include moraines with CRE ages ranging from $15.5 \pm 0.4$ to $13.2 \pm 1.0 \mathrm{ka}$, leading 659 to an averaged CRE age of $14.7 \pm 0.9 \mathrm{ka}(\mathrm{n}=14)$ (Table 6, Fig. 9C) (Engel et al., 2014, 660 2017; Gheorghiu et al, 2015; Makos et al., 2018; Zasadni et al., 2020). Their stabilization 661 might be related to the beginning of the B-A. Only 6 cirques included moraine formation 662 during the YD/Early Holocene transition, whose CRE ages range between $12.0 \pm 1.1$ and $66310.9 \pm 0.6 \mathrm{ka}$, leading to an averaged CRE age of $11.6 \pm 0.7 \mathrm{ka}(\mathrm{n}=6)($ Table 6, Fig. 9.C) 664 (Engel et al., 2017; Gheorghiu et al, 2015; Makos et al., 2018). The YD glaciers had 665 limited areas, with lengths between 500 and $800 \mathrm{~m} .6$ cirques do not host YD moraines, 666 but include rock glaciers, whose fronts stabilized at CRE ages ranging from $12.9 \pm 0.7$ to $66710.9 \pm 1.0 \mathrm{ka}$, also during the YD/Early Holocene transition (Moran et al., 2016; Zasadni 668 et al., 2020) (Table 6). There is no evidence of Neoglacial landforms.

669 (iii) Six cirques from the British Isles and three from northern Iceland were analyzed 670 (Table 7). Only three British cirques provide information regarding their initial 
671 deglaciation. They became ice-free prior to or during the B-A at an average age of $15.2 \pm$

$6721.1 \mathrm{ka} \mathrm{(n=3)} \mathrm{(Table} \mathrm{7,} \mathrm{Fig.} \mathrm{9D)} \mathrm{(Barth} \mathrm{et} \mathrm{al.,} \mathrm{2018).} \mathrm{Four} \mathrm{British} \mathrm{and} \mathrm{two} \mathrm{Icelandic} \mathrm{cirques}$ 673 host moraines whose stabilization ages range from $12.0 \pm 0.9$ to $10.7 \pm 1.0 \mathrm{ka}$, leading to 674 an average age of $11.6 \pm 1.1 \mathrm{ka}(\mathrm{n}=6)$ (Table 7, Fig. 9D). Therefore, they probably formed 675 during the YD (Barth et al., 2018; Hughes et al., 2019; Fernández-Fernández et al., 2020). 676 The British YD cirque glaciers were between 300 and $950 \mathrm{~m}$ long while the Icelandic 677 ones were longer, between 1500 and $3000 \mathrm{~m}$. The stabilization of one rock glacier has 678 been dated in Britain at $12.5 \pm 1.1 \mathrm{ka}(\mathrm{n}=5$; Barth et al., 2018) and two others in Iceland 679 lead to a reported average age of $10.1 \pm 1.0 \mathrm{ka} \mathrm{(n=4;} \mathrm{Fernández-Fernández} \mathrm{et} \mathrm{al.,} \mathrm{2020).}$

680 (iv) Until very recently, chronological data about the formation of landforms inside 681 glacial cirques from North America was very limited, but a recent study provides 682 information about cirques from the Western United States (Marcott et al., 2019). Located 683 between $35^{\circ}$ to $47^{\circ} \mathrm{N}, 12$ cirques were examined (Table 8). Six of these cirques provide 684 deglaciation ages based on the chronology of the stabilization of their moraines that 685 occurred during the B-A, their ages between $15.2 \pm 0.7$ and $13.4 \pm 0.7 \mathrm{ka}$ lead to an 686 average age of $14.4 \pm 0.8 \mathrm{ka}(\mathrm{n}=6)$ (Table 8, Fig. 9E) (Marcott et al., 2019). Eight of the 687 American cirques have internal moraines whose ages between $12.8 \pm 0.7$ and $10.7 \pm 0.6$ $688 \mathrm{ka}$ lead to an average age of $12.0 \pm 0.7 \mathrm{ka}(\mathrm{n}=8)$ likely corresponding to the YD (Table 8, 689 Fig. 9.E) (Marcott et al., 2019). Theses YD glaciers were between 700 and $2800 \mathrm{~m}$ long. 690 Three of these cirques have rock glaciers whose ages of stabilization range between 10.5 $691 \pm 0.6$ and $9.6 \pm 0.5 \mathrm{ka}$ (Marcott et al., 2019).

692 (v) The comparison of the different deglaciation chronologies and of the development of 693 rock glaciers allows inferring if there is a synchronic pattern across the Northern 694 Hemisphere. The comparison of all the averaged ages of the rock glacier front 695 stabilization reveals that they chronologically coincide with phases following the 696 deglaciation of these cirques, i.e. fifteen of them (average age: $10.8 \pm 0.7 \mathrm{ka}$ ) after the 697 YD, and 5 of them (average age: $15.4 \pm 1.5 \mathrm{ka}$ ) with the end of the OD (Table 3, 4, 5, 6, 6987 and 8 and Fig. 9.F). Since most of the analysed cirques were deglaciated after the YD, 699 most of the rock glacier fronts stabilized shortly thereafter, around 1 ka after deglaciation 700 (Palacios et al., 2016; Moran et al., 2016; Palacios et al., 2017a; Fernández-Fernández et 701 al., 2020; Marcott et al., 2019; Zasadni et al., 2020).

702 (vi) Based on the typology and age of the landforms observed inside the cirques in the 703 mid-latitude mountains of the Northern Hemisphere, we concluded that the 
geomorphological dynamics of all these cirques were similar to those studied in the Sierra

705 Nevada and in the rest of the Iberian Peninsula (Fig. 10). As in the Sierra Nevada, the 706 diversity of geomorphic landforms in each cirque depends on the local topographic 707 characteristics of the altitude of its summits and floors as well as on its orientation and 708 prevailing lithology. However, most of the moraine systems and rock glaciers distributed 709 inside glacial cirques formed during the same climatic phases throughout the Hemisphere,

710 from the Last Termination to the present.

711 In fact, two distinct geomorphological phases are clearly linked to the warm phases during 712 the Last Termintion in the Northern Hemisphere: (i) The glacier margins receded from 713 the mouth of the cirques - generating in many cases moraines - during the climate 714 oscillations of the OD and the B-A transition; (ii) in most cirques, the glaciers expanded 715 or remained during the YD and generated moraines within the limits of the cirques. These 716 glaciers retreated up-valley and abandoned their moraines at the onset of the Holocene, 717 when rock glacier fronts stabilized (Fig. 10).

\section{6. Conclusions}

719 This work provides robust evidence that glacial cirques reflect the climatic conditions 720 prevailing during their formation (Benedict, 1973; Dahl and Nesje, 1992; Delmas et al., 721 2015; Barr et al., 2017; Barr and Spagnolo, 2015; Ipsen et al., 2018), and also preserve very valuable information on the climatic and geomorphological evolution that occurred during their deglaciation:

724 (i) All the examined cirques were deglaciated during the OD and the B-A transition. There 725 are no geomorphic remnants in none of the examined cirques of the Northern Hemisphere supporting the existence of glaciers during the B-A. Although survival of glaciers through the B-A in the cirques is fully possible, it is not proven. While glaciers retreated during the OD and B-A transition in many cirques, in others the glaciers evolved into rock glaciers but their fronts stabilized soon after their formation.

730 (ii) There is widespread evidence of the existence of glaciers during the YD in many 731 cirques, as shown by: (i) the age of glacier retreat revealed by the age of polished bedrock surfaces, and (ii) the age of moraine boulders stabilization. In both cases, results provide ages spanning the late YD and early Holocene.

734 (iii) The retreat of YD glaciers generated a wide variety of landforms within each cirque:

735 (a) Sometimes, after the glaciers disappeared, only polished surfaces remained. This is a 
736 widespread pattern in Iberian mountains, and probably in other mid-latitude mountains,

737 although in other regions there are very few studies that have dated bedrock surfaces 738 located at the bottom of the cirques. (b) In other cases, following the melting of glaciers, 739 moraines rapidly stabilized. (c) Moraines did not form in many cirques, but the retreat of 740 YD glaciers favoured the development of rock glaciers. In many cases, their fronts 741 stabilized shortly after their formation, even in less than 1 ka (Zasadni et al., 2020). (d)

742 In other cases, debris-covered glaciers could also form. In fact, many of the analysed rock 743 glaciers may have originated from debris covered glaciers formed in previous phases of 744 the long-term deglaciation process (Anderson et al., 2018). The detailed study conducted on the wide variety of cirques in the Sierra Nevada provided information about the topographical setting that determined every type of evolution. Similar studies should be done in other mountain systems to better determine every single type of geomorphological evolution and infer the role of climate, topography and lithology in their evolution.

(iv) In most cirques, no major changes have occurred on geomorphological dynamics since the HTM. Landscapes have only undergone minor transformations related to periglacial and slope processes. Neoglacial landforms only developed in the highest mountains, such as in the case of the Sierra Nevada, where glaciers developed in cirques with summits exceeding $3300 \mathrm{~m}$. The diversity of cirque landforms depends on local conditions and, above all, on the geomorphological activity of their headwalls. In some cases, the retreat of small Neoglacial ice masses triggered the formation of incipient rock glaciers.

758 (v) This study highlights that the formation of rock glaciers inside the cirques is triggered by the onset of warm phases that accelerate the retreat of glaciers. Therefore, they are more associated with the paraglacial readjustment following glacial retreat (Ballantyne, 2002) rather than with a periglacial origin driven by very cold temperatures. This explains the rapid stabilization of their fronts once the internal frozen body disappears (GómezOrtiz et al., 2014).

764 Glacial cirques have been shown to be highly climatically sensitive areas where small 765 changes favoured the development or disappearance of glaciers. In addition, the activity 766 of their walls is critical to generate a great variety of landforms, depending on their 767 topographic characteristics. Glacial cirques are, therefore, a valuable source of 
palaeoenvironmental information to better understand the landscape evolution of mountain systems since the last deglaciation to recent times.

770

771

772

773

774

775

776

777

778

779

780

781

782

783

784

785

786

787

788

789

790

791

792

793

794

795

796

797

798

799

800

801

802

803

804

805

806

807

\section{Acknowledgements}

This research article was supported by the project CGL2015-65813-R (Spanish Ministry of Economy and Competitiveness) and NUNANTAR (02/SAICT/2017 - 32002; Fundação para a Ciência e a Tecnologia, Portugal). It also complements the research topics examined in the project PALAEOGREEN (CTM2017-87976-P; Spanish Ministry of Economy and Competitiveness). The ${ }^{10} \mathrm{Be}$ measurements were performed at the ASTER AMS national facility (CEREGE, Aix-en-Provence), which is supported by the INSU/CNRS and the ANR through the "Projets thématiques d'excellence" program for the "Equipements d'excellence" ASTER-CEREGE action and IRD. Marc Oliva is supported by the Ramón y Cajal Program (RYC-2015-17597) and the Research Group ANTALP (Antarctic, Arctic, Alpine Environments; 2017-SGR-1102). The authors are deeply appreciative for the detailed analyses and excellent suggestions made by the two reviewers, Drs. Ian Evans and Philip Hughes, who helped to considerably improve many aspects of this work.

\section{References}

Anderson, R.S., Anderson, L.S., Armstrong, W.H., Rossi, M.W., Crump, S.E., 2018. Glaciation of alpine valleys: The glacier-debris-covered glacier-rock glacier continuum. Geomorphology 311, 127-142. https://doi.org/10.1016/j.geomorph.2018.03.015.

Anderson, R.S., Jiménez-Moreno, G., Carrión, J.S., Pérez-Martínez, C., 2011. Postglacial history of alpine vegetation, fire, and climate from Laguna de Río Seco, Sierra Nevada, southern Spain. Quat. Sci. Rev. 30, 1615-1629. https://doi.org/10.1016/j.quascirev.2011.03.005

Andrés, N., Gómez-Ortiz, A., Fernández-Fernández, J. M., Tanarro, L.M., Salvador, F., Oliva, M.;, Palacios, D., 2019. Timing of deglaciation and rock glacier origin in the southeastern Pyrenees: a review and new data. Boreas 47, 1050-1071. https://doi.org/10.1111/bor.12324.

Arnold, M., Merchel, S., Bourlès, D.L., Braucher, R., Benedetti, L., Finkel, R.C., Aumaître, G., Gottdang, A., Klein, M., 2010. The French accelerator mass spectrometry facility ASTER: Improved performance and developments. Nuclear Instruments and Methods in Physics Research, Section B, Beam Interactions with Materials and Atoms, 19th International Conference on Ion Beam Analysis 268, 1954-1959. https://doi.org/10.1016/j.nimb.2010.02.107

Ballantyne, C.K. 2002. Paraglacial geomorphology. Quaternary Science Reviews, 21, 1935-2017. https://doi.org/10.1016/S0277-3791(02)00005-7

Ballantyne, C.K., 2013. Paraglacial Geomorphology, in: Encyclopedia of Quaternary Science: Second Edition. Elsevier, pp. 553-565. https://doi.org/10.1016/B978-0444-53643-3.00089-3 
Baroni, C., Guidobaldi, G., Salvatore, M. C., Christl, M., Ivy-Ochs, S., 2018. Last glacial maximum glaciers in the Northern Apennines reflect primarily the influence of southerly storm-tracks in the western Mediterranean. Quaternary Science Reviews 197, 352-367. https://doi.org/10.1016/j.quascirev.2018.07.003.

Barr, I. D., Spagnolo, M. 2015. Glacial cirques as palaeoenvironmental indicators: Their potential and limitations. Earth-science reviews, 151, 48-78. http://dx.doi.org/10.1016/i.earscirev.2015.10.004

Barr, I. D., Ely, J. C., Spagnolo, M., Clark, C. D., Evans, I. S., Pellicer, X. M., ... \& Rea, B. R. 2017. Climate patterns during former periods of mountain glaciation in Britain and Ireland: Inferences from the cirque record. Palaeogeography, palaeoclimatology, palaeoecology, 485, 466-475. https://doi.org/10.1016/j.palaeo.2017.07.001

Barth, A. M., Clark, P. U., Clark, J., McCabe, A. M., \& Caffee, M. 2016. Last Glacial Maximum cirque glaciation in Ireland and implications for reconstructions of the Irish Ice Sheet. Quaternary Science Reviews, 141, 85-93. https://doi.org/10.1016/j.quascirev.2016.04.006

Barth, A. M., Clark, P. U., Clark, J., Roe, G. H., Marcott, S. A., McCabe, A. M., ... \& Dunlop, P. 2018. Persistent millennial-scale glacier fluctuations in Ireland between $24 \mathrm{ka}$ and $10 \mathrm{ka}$. Geology, 46(2), 151-154. https://doi.org/10.1130/G39796.1

Benedict, J. B. 1973. Chronology of cirque glaciation, Colorado front range. Quaternary Research, 3(4), 584-599.

Benn, D.I., Evans, D.J.A., 2010. Glaciers and Glaciation. Hodder Education, London. Braucher, R., Guillou, V., Bourlès, D.L., Arnold, M., Aumaître, G., Keddadouche, K., Nottoli, E., 2015. Preparation of ASTER in-house ${ }^{10} \mathrm{Be} /{ }^{9} \mathrm{Be}$ standard solutions. Nuclear Instruments and Methods in Physics Research, Section B, Beam Interactions with Materials and Atoms, The Thirteenth Accelerator Mass Spectrometry Conference 361, 335-340. https://doi.org/10.1016/j.nimb.2015.06.012

Carrasco, R.M., Pedraza, J., Dominguez-Villar, D., Willenbring, J.K., Villa, J., 2013. Supraglacial debris supply in the Cuerpo de Hombre palaeoglacier (Spanish Central System). Reconstruction and interpretation of a rock avalanche event. Geogr. Ann. Ser. A Phys. Geogr. 95, 211-266. https://doi.org/10.1111/geoa.12010

Carrasco R.M., Pedraza J., Dominguez-Villar D., Willenbring J.K., Villa J., 2015. Sequence and chronology of the Cuerpo de Hombre palaeoglacier (Iberian Central System) during the last glacial cycle. Quat Sci Rev. 129, 163-177. https://doi.org/10.1016/j.quascirev.2015.09.021

Carrasco, R.M, Pedraza, J., Willenbring, J. Karampaglidis, T., Soteres, R.L., MartínDuque, J.F., 2016. Morfología glaciar del Macizo de Los Pelados-El Nevero (Parque Nacional de la Sierra de Guadarrama). Nueva interpretación y cronología. Bol. R. Soc. Esp. Hist. Nat. Sec. Geol. 110, 49-66.

Çiner, A., Sarikaya, M.A., Yildirim, C., 2017. Misleading old age on a young landform? The dilemma of cosmogenic inheritance in surface exposure dating: Moraines vs. rock glaciers. Quaternary Geochronology 42, 76-88. https://doi.org/10.1016/j.quageo.2017.07.003

Chmeleff, J., von Blanckenburg, F., Kossert, K., Jakob, D., 2010. Determination of the ${ }^{10} \mathrm{Be}$ half-life by multicollector ICP-MS and liquid scintillation counting Nuclear Instruments and Methods in Physics Research, Section B, Beam Interactions with Materials and Atoms 268, 192-199. https://doi.org/10.1016/j.nimb.2009.09.012

Clark, D. H., Gillespie, A. R. 1997. Timing and significance of late-glacial and Holocene cirque glaciation in the Sierra Nevada, California. Quaternary 
International, 38, 21-38. https://doi.org/10.1016/S1040-6182(96)00024-9

Clark, P.U., Dyke, A.S., Shakun, J.D., Carlson, A.E., Clark, J., Wohlfarth, B., Mitrovica, J.X., Hostetler, S.W., McCabe, A. 2009. The Last Glacial Maximum. Science 325, 710-714. 10.1126/science.1172873

Crest, Y., Delmas, M., Braucher, R., Gunnell, Y., Calvet, M., \& Aster Team. 2017. Cirques have growth spurts during deglacial and interglacial periods: Evidence from ${ }^{10} \mathrm{Be}$ and ${ }^{26} \mathrm{Al}$ nuclide inventories in the central and eastern Pyrenees. Geomorphology, 278, 60-77. http://dx.doi.org/10.1016/j.geomorph.2016.10.035

CRONUS-Earth Web Calculators v2.0 2020: Available at: http://cronus.cosmogenicnuclides.rocks/2.0/html/topo/ (accessed March 2020).

Dahl, S. O., Nesje, A. 1992. Palaeoclimatic implications based on equilibrium-line altitude depressions of reconstructed Younger Dryas and Holocene cirque glaciers in inner Nordfjord, western Norway. Palaeogeography, Palaeoclimatology, Palaeoecology, 94(1-4), 87-97. https://doi.org/10.1016/0031-0182(92)90114-K

Deline, P., Akçar, N., Ivy-Ochs, S., Kubik, P.W., 2015. Repeated Holocene rock avalanches onto the Brenva Glacier, Mont Blanc massif, Italy: A chronology. Quat. Sci. Rev. 126, 186-200 http://dx.doi.org/10.1016/j.quascirev.2015.09.004

Delmas, M., 2015. The last maximum ice extent and subsequent deglaciation of the Pyrenees: an overview of recent research. Cuadernos de Investigación Geográfica 41 (2), 359-387. http://dx.doi.org/10.18172/cig.2708

Delmas, M., Gunnell, Y., Calvet, M., 2015. A critical appraisal of allometric growth among alpine cirques based on multivariate statistics and spatial analysis. Geomorphology 228, 637-652. https://doi.org/10.1016/j.geomorph.2014.10.021

Domínguez-Villar, D., Carrasco, R.M., Pedraza, J., Cheng, H., Edwards, R.L., Willenbring, J.K. 2013. Early maximum extent of palaeoglaciers from Mediterranean mountains during the last glaciation. Sci. Rep. 3, 2034. https://doi.org/10.1038/srep02034

Engel, Z., Braucher, R., Traczyk, A., \& Laetitia, L. 2014. ${ }^{10}$ Be exposure age chronology of the last glaciation in the Krkonoše Mountains, Central Europe. Geomorphology, 206, 107-121. http://dx.doi.org/10.1016/j.geomorph.2013.10.003

Engel, Z., Mentlík, P., Braucher, R., Minár, J., Léanni, L., Aster Team 2015. Geomorphologicalal evidence and ${ }^{10} \mathrm{Be}$ exposure ages for the Last Glacial Maximum and deglaciation of the Velká and Malá Studená dolina valleys in the High Tatra Mountains, central Europe. Quaternary Science Reviews, 124, 106-123. http://dx.doi.org/10.1016/j.quascirev.2015.07.015

Engel, Z., Braucher, R., Traczyk, A., \& Laetitia, L. 2014. ${ }^{10}$ Be exposure age chronology of the last glaciation in the Krkonoše Mountains, Central Europe. Geomorphology, 206, 107-121. https://doi.org/10.1016/j.geomorph.2013.10.003

Evans, I.S., Cox, N.J., 1974. Geomorphometry and the operational definition of cirques. Area 6, 150-153.

Evans, I.S., Cox, N.J., 1995. The formof glacial cirques in the English Lake District, Cumbria. Z. Geomorphol. 39, 175-202.

Fernández-Fernández, J.M., Palacios, D., García-Ruiz, J.M., Andrés, N., Schimmelpfennig, I., Gómez-Villar, A., Santos González, J., Álvarez-Martínez, J., Arnáez, J., Úbeda, J., Léanni, L., ASTER Team, 2017. Chronological and geomorphologicalal investigation of fossil debris-covered glaciers in relation to deglaciation processes: A case study in the Sierra de la Demanda, northern Spain. Quaternary Science Reviews 170, 232-249. https://doi.org/10.1016/j.quascirev.2017.06.034

Fernández-Fernández, J.M., Palacios, D., Andrés, N., Schimmelpfennig, I., 
Brynjólfsson, S., Sancho, L.G., Zamorano, J.J., Heiðmarsson, S., Sæmundsson, P., ASTER Team 2019. A multi-proxy approach to Late Holocene fluctuations of Tungnahryggsjökull glaciers in the Tröllaskagi peninsula (northern Iceland) Science of the Total Environment, 664, 499-517. Citations: 1. https://doi.org/10.1016/j.scitotenv.2019.01.364

Fernández-Fernández, J.M., Palacios, D., Andrés, N., Schimmelpfennig, I., Tanarro, L.M., Brynjólfsson, S., López-Acevedo, F.J., Sæmundsson, P., Team, A.S.T.E.R., 2020. Constraints on the timing of debris-covered and rock glaciers: An exploratory case study in the Hólar area, northern Iceland. Geomorphology 361, 107196. https://doi.org/10.1016/j.geomorph.2020.107196

Fletcher, W.J., Sánchez Goñi, M.F., Allen, J.R.M., Cheddadi, R., Cambourieu-Nebout, N., Huntley, B., Lawson, I., Londeix, L., Magri, D., Margari, V., Muller, U.C., Naughton, F., Novenko, E., Roucoux, K., Tzedakis, P.C., 2010a. Millennial-scale variability during the last glacial in vegetation records from Europe. Quaternary Science Reviews 29 (21-22), 2839-2864. https://doi.org/10.1016/j.quascirev.2009.11.015

Fletcher, W.J., Sánchez-Goñi, M.F., Peyron, O., Dormoy, I., 2010b. Abrupt climate changes of the last deglaciation. Western Mediterranean forest record. Climate of the Past 6, 245-264. https://doi.org/10.5194/cp-6-245-2010

García-Alix, A., Jimenez-Espejo, F.J., Lozano, J.A., Jiménez-Moreno, G., MartinezRuiz, F., García Sanjuán, L., Aranda Jiménez, G., García Alfonso, E., RuizPuertas, G., Anderson, R.S., 2013. Anthropogenic impact and lead pollution throughout the Holocene in Southern Iberia. Sci. Total Environ. 449, 451-460. https://doi.org/10.1016/j.scitotenv.2013.01.081

García-Alix, A., Jiménez-Espejo, F.J., Toney, J.L., Jiménez-Moreno, G., RamosRomán, M.J., Anderson, R.S., Ruano, P., Queralt, I., Delgado Huertas, A., Kuroda, J., 2017. Alpine bogs of southern Spain show human-induced environmental change superimposed on long-term natural variations. Sci. Rep. 7, 1-12. https://doi.org/10.1038/s41598-017-07854-w

García-Ruiz, J. M., Palacios, D., de Andrés, N., Valero-Garcés, B.L., López-Moreno, J.I., Sanjuán, Y., 2014. Holocene and 'little ice age' glacial activity in the Marboré cirque, Monte Perdido massif, central Spanish Pyrenees. The Holocene 24 (11), 1439-1452. https://doi.org/10.1177/0959683614544053.

García-Ruiz, J. M., Palacios, D., González-Sampériz, P., De Andrés, N., Moreno, A., Valero-Garcés, B., \& Gómez-Villar, A. 2016. Mountain glacier evolution in the Iberian Peninsula during the Younger Dryas. Quaternary Science Reviews, 138, 16-30. https://doi.org/10.1016/j.quascirev.2016.02.022

García-Ruiz, J.M., Palacios,D., Fernández-Fernández, J.M., Andrés, N. Arnáez, J. Gómez-Villar A., Santos-González, J., Álvarez-Martínez, J., Lana-Renault, N. Léanni, L. ASTER Team 2020a. Glacial stages in the Peña Negra valley, Iberian Range, northern Iberian Peninsula: Assessing the importance of the glacial record in small cirques in a marginal mountain area. Geomorphology (revision).

García-Ruiz, J.M., Palacios,D., Andrés, N., López-Moreno,J.I., 2020b. Neoglaciation in the Spanish Pyrenees: A multiproxy challenge. Mediterranean Geoscience Reviews. https://doi.org/10.1007/s42990-020-00022-9

Gheorghiu, D. M., Hosu, M., Corpade, C., \& Xu, S. 2015. Deglaciation constraints in the Parâng Mountains, Southern Romania, using surface exposure dating. Quaternary International, 388, 156-167. http://dx.doi.org/10.1016/j.quaint.2015.04.059

Giraudi, C., 2012. The campo felice late pleistocene glaciation (Apennines, Central 
Italy). J. Quat. Sci. 27, 432e440. https://doi.org/10.1002/jqs.1569

Gómez-Ortiz, A., Palacios, D., Schulte, L., Salvador-Franch, F., Plana-Castellví, J.A., 2009. Evidences from historical documents of landscape evolution after little ice age of a mediterranean high mountain area, Sierra Nevada, Spain (eighteenth to twentieth centuries). Geogr. Ann. Ser. A Phys. Geogr. 91, 279-289. https://doi.org/10.1111/j.1468-0459.2009.00370.x

Gómez-Ortiz, A., Oliva, M., Salvador-Franch, F., Salvà-Catarineu, M., Plana-Castellví, J.A., 2018. The geographical interest of historical documents to interpret the scientific evolution of the glacier existing in the Veleta cirque (Sierra Nevada, Spain) during the Little Ice Age. Cuadernos de Investigación Geográfica 44, $267-$ 292.

Gómez-Ortiz, A., Oliva, M., Salvador-Franch, F., Palacios, D., Tanarro, L.M., SanjoséBlasco, J.J., Salvà-Catarineu, M., 2019. Monitoring permafrost and periglacial processes in Sierra Nevada (Spain) from 2001 to 2016. Permafr. Periglac. Process. https://doi.org/10.1002/PPP.2002

Gómez-Ortiz, A., Oliva, M., Palacios, D., Salvador-Franch, F., Vázquez-Selem, L., Salvà-Catarineu, M., De Andrés, N., 2015. The deglaciation of Sierra Nevada (Spain), synthesis of the knowledge and new contributions. Cuad. Investig. Geográfica 41, 409. https://doi.org/10.18172/cig.2722

Gómez-Ortiz, A., Palacios, D., Palade, B., Vázquez-Selem, L., Salvador-Franch, F., 2012. The deglaciation of the Sierra Nevada (Southern Spain). Geomorphology 159-160, 93-105. https://doi.org/10.1016/j.geomorph.2012.03.008

Hippolyte, J.C., Bourlès, D., Braucher, R., Carcaillet, J., Léanni, L., Arnold, M., Aumaitre, G., 2009: Cosmogenic ${ }^{10} \mathrm{Be}$ dating of a sackung and its faulted rock glaciers, in the Alps of Savoy (France). Geomorphology 108, 312-320 http://www.springer.com/us/book/9783642800955.

Hughes, P.D., Woodward, J.C., Gibbard, P.L., Macklin, M.G., Gilmour, M.A., Smith, G.R., 2006. The glacial history of the Pindus Mountains, Greece. J. Geol. 114, 413-434. https://doi.org/10.1086/504177

Hughes, P.D., Gibbard, P.L.,Woodward, J.C., 2007. Geological controls on Pleistocene glaciation and cirque form in Greece. Geomorphology 88 (3), 242-253. https://doi.org/10.1016/j.geomorph.2006.11.008

Hughes, P.D., Gibbard, P.L., Ehlers, J. 2013. Timing of glaciation during the last glacial cycle: Evaluating the concept of a global 'Last Glacial Maximum' (LGM). EarthSci. Rev. 125, 171-198. https://doi.org/10.1016/j.earscirev.2013.07.003

Hughes, P.D., Fink, D., Rodés, Á., Fenton, C.R., Fujioka, T., 2018. Timing of Pleistocene glaciations in the High Atlas, Morocco: $\mathrm{New}{ }^{10} \mathrm{Be}$ and ${ }^{36} \mathrm{Cl}$ exposure ages. Quaternary Science Reviews, 180, 193-213. https://doi.org/10.1016/j.quascirev.2017.11.015.

Hughes, P. D., Gibbard, P. L. 2018. Global glacier dynamics during 100 ka Pleistocene glacial cycles. Quaternary Research, 90(1), 222-243. https://doi.org/10.1017/qua.2018.37

Hughes, P.D., Tomkins, M.D., Stimson,G.A. 2019. Glaciation of the English Lake District during the Late-glacial: a new analysis using ${ }^{10} \mathrm{Be}$ and Schmidt hammer exposure dating. North West Geography, 19(2), 8-20.

Ipsen, H.A., Principato, S.M., Grube, R.E., Lee, J.F., 2018. Spatial analysis of cirques from three regions of Iceland: implications for cirque formation and palaeoclimate. Boreas 47, 565-576. https://doi.org/10.1111/bor.12295

Ivy-Ochs, S., Kerschner, H., Maisch, M., Christl, M., Kubik, P.W., Schlüchter, C., 2009. Latest Pleistocene and Holocene glacier variations in the European Alps. 
Quat. Sci. Rev. 28, 2137-2149. https://doi.org/10.1016/j.quascirev.2009.03.009.

Ivy-Ochs, S., 2015. Glacier variations in the European Alps at the end of the last glaciation. Cuadernos de Investigación Geográfica, 41 (2), 295-315. Doi: https://doi.org/110.18172/cig.2750

Jiménez-Moreno, G., Anderson, R.S., 2012. Holocene vegetation and climate change recorded in alpine bog sediments from the Borreguiles de la Virgen, Sierra Nevada, southern Spain. Quat. Res. 77, 44-53. https://doi.org/10.1016/j.yqres.2011.09.006

Jomelli V., Chapron E., Favier V., Rinterknecht V., Braucher R., Tournier N., Gascoin S., Marti R., Galop D., Binet S., Deschamps-Berger C., Tissoux H., ASTER Team. 2020. Glacier fluctuations during the Late Glacial and Holocene on the Ariege valley, northern slope of the Pyrenees and reconstructed climatic conditions. Mediterranean. Geosci. Rev. 1-15 https://doi.org/10.1007/s42990-020-00018-5

Kleman, J., Stroeven, A.P., 1997. Preglacial surface remnants and Quaternary glacial regimes in northwestern Sweden. Geomorphology 19 (1), 35-54. https://doi.org/10.1016/S0169-555X(96)00046-3

Knight, J., Harrison, S., Jones, D.B., 2018. Rock glaciers and the geomorphologicalal evolution of deglacierizing mountains. Geomorphology 311, 127-142.

https://doi.org/10.1016/j.geomorph.2018.09.020

Korschinek, G., Bergmaier, A., Faestermann, T., Gerstmann, U.C., Knie, K., Rugel, G., Wallner, A., Dillmann, I., Dollinger, G., von Gostomski, C.L., Kossert, K., Maiti, M., Poutivtsev, M., Remmert, A., 2010. A new value for the half-life of ${ }^{10} \mathrm{Be}$ by Heavy-Ion Elastic Recoil Detection and liquid scintillation counting. Nuclear Instruments and Methods in Physics Research, Section B, Beam Interactions with Materials and Atoms 268, 187-191. https://doi.org/10.1016/j.nimb.2009.09.020

Köse, O., Sarikaya, M. A., Çiner, A., Candaş, A., 2019. Late Quaternary glaciations and cosmogenic ${ }^{36} \mathrm{Cl}$ geochronology of Mount Dedegöl, south-west Turkey. Journal of Quaternary Science, 34 (1), 51-63. https://doi.org/10.1002/jqs.3080.

Kuhlemann, J., Gachev, E., Gikov, A., Nedkov, S., Krumrei, I., Kubik, P. 2013. Glaciation in the Rila Mountains (Bulgaria) during the last glacial maximum. Quaternary International, 293, 51-62. http://dx.doi.org/10.1016/j.quaint.2012.06.027

Laabs, B. J., Licciardi, J. M., Leonard, E. M., Munroe, J. S., \& Marchetti, D. W. 2020. Updated cosmogenic chronologies of Pleistocene mountain glaciation in the western United States and associated palaeoclimate inferences. Quaternary Science Reviews, 242, 106427. https://doi.org/10.1016/j.quascirev.2020.106427

Le Roy, M., Deline, P., Carcaillet, J., Schimmelpfennig, I., Ermini, M., ASTER Team, 2017. ${ }^{10} \mathrm{Be}$ exposure dating of the timing of Neoglacial glacier advances in the Ecrins-Pelvoux massif, southern French Alps. Quaternary Science Reviews, 178, 118-138. https://doi.org/10.1016/j.quascirev.2017.10.010

Li, Y., Li, Y., Harbor, J., Liu, G., Yi, C., Caffee, M.W., 2016. Cosmogenic ${ }^{10} \mathrm{Be}$ constraints on Little Ice Age glacial advances in the eastern Tian Shan, China. Quat. Sci. Rev. 138, 105-118. https://doi.org/10.1016/j.quascirev.2016.02.023

Licciardi, J. M., Pierce, K. L. 2008. Cosmogenic exposure-age chronologies of Pinedale and Bull Lake glaciations in greater Yellowstone and the Teton Range, USA. Quaternary Science Reviews, 27(7-8), 814-831. https://doi.org/10.1016/j.quascirev.2007.12.005

Lifton, N., Sato, T., Dunai, T.J., 2014. Scaling in situ cosmogenic nuclide production rates using analytical approximations to atmospheric cosmic-ray fluxes. Earth Planet. Sci. Lett. 386, 149-160. https://doi.org/10.1016/j.eps1.2013.10.052

López-Sáez, J. A., Carrasco, R. M., Turu, V., Ruiz-Zapata, B., Gil-García, M. J., 
Luelmo-Lautenschlaeger, R., ... \& Pedraza, J., 2020. Late Glacial-early holocene vegetation and environmental changes in the western Iberian Central System inferred from a key site: The Navamuño record, Béjar range (Spain). Quaternary Science Reviews, 230, 106167. https://doi.org/10.1016/j.quascirev.2020.106167

Makos, M., Rinterknecht, V., Braucher, R., Tołoczko-Pasek, A., Arnold, M., Aumaître, G., ... Keddadouche, K. 2018. Last Glacial Maximum and Lateglacial in the Polish High Tatra Mountains-Revised deglaciation chronology based on the ${ }^{10} \mathrm{Be}$ exposure age dating. Quaternary Science Reviews, 187, 130-156. https://doi.org/10.1016/j.quascirev.2018.03.006

Mangerud, J. A. N., Landvik, J. Y. 2007. Younger Dryas cirque glaciers in western Spitsbergen: smaller than during the Little Ice Age. Boreas, 36(3), 278-285 https://doi.org/10.1080/03009480601134827

Manzano, S., Carrión, J.S., López-Merino, L., Jiménez-Moreno, G., Toney, J.L., Amstrong, H., Anderson, R.S., García-Alix, A., Pérez, J.L.G., Sánchez-Mata, D., 2019. A palaeoecological approach to understanding the past and present of Sierra Nevada, a Southwestern European biodiversity hotspot. Glob. Planet. Change 175, 238-250. https://doi.org/10.1016/j.gloplacha.2019.02.006

Martin, L., Blard, P.-H., Balco, G., Lave, J., Delunel, R., Lifton, N., Laurent, V., 2017. The CREp program and the ICE-D production rate calibration database: a fully parameterizable and updated online tool to compute cosmic-ray exposure ages. Quat. Geochronol. 38, 25-49. https://doi.org/10.1016/j.quageo.2016.11.006

Marcott, S.A., Clark, P.U., Shakun, J.D., Brook, E.J., Davis, P.T., Caffee, M.W. 2019. ${ }^{10} \mathrm{Be}$ age constraints on latest Pleistocene and Holocene cirque glaciation across the western United States. Clim. Atmos. Sci. 2(5). https://doi.org/10.1038/s41612-0190062-Z

Mercier, D., Coquin, J., Feuillet, T., Decaulne, A., Cossart, E., Jónsson, H.P., Sæmundsson, P., 2017. Are Icelandic rock-slope failures paraglacial? Age evaluation of seventeen rock-slope failures in the Skagafjörður area, based on geomorphologicalal stacking, radiocarbon dating and tephrochronology. Geomorphology 296, 45-58. https://doi.org/10.1016/j.geomorph.2017.08.011

Merchel, S., Herpers, U. 1999. An update on radiochemical separation techniques for the determination of long-lived radionuclides via accelerator mass spectrometry. Radiochimica Acta, 84(4), 215-220. https://doi.org/10.1524/ract.1999.84.4.215

Merchel, S., Arnold, M., Aumaître, G., Benedetti, L., Bourlès, D.L., Braucher, R., Alfimov, V., Freeman, S.P.H.T., Steier, P., Wallner, A., 2008. Towards more precise ${ }^{10} \mathrm{Be}$ and ${ }^{36} \mathrm{Cl}$ data from measurements at the $10-14$ level: Influence of sample preparation. Nuclear Instruments and Methods in Physics Research, Section B, Beam Interactions with Materials and Atoms 266, 4921-4926. https://doi.org/10.1016/j.nimb.2008.07.031

Mîndrescu, M., Evans, I. S. 2014. Cirque form and development in Romania: Allometry and the buzzsaw hypothesis. Geomorphology, 208, 117-136.

https://doi.org/10.1016/j.geomorph.2013.11.019

Moran, A.P., Ivy-Ochs, S., Vockenhuber, C., Kerschner, H., 2016. Rock glacier development in the Northern Calcareous Alps at the Pleistocene-Holocene boundary. Geomorphology 273, 178-188. https://doi.org/10.1016/j.geomorph.2016.08.017.

Moreno, A., Svensson, A., Brooks, S.J., Connor, S., Engels, S., Fletcher, W., Genty, D., Heiri, O., Labuhn, I., Persoiu, A., Peyron, O., Sadori, L., Valero-Garcés, B., Wulf, S., Zanchetta, G., 2014. A compilation of Western European terrestrial records 60$8 \mathrm{ka}$ BP: towards an understanding of latitudinal climatic gradients. Quaternary 
Science Reviews 106, 167-185. https://doi.org/10.1016/j.quascirev.2014.06.030

Oliva, M., Schulte, L., Gómez-Ortiz, A., 2008. Solifluction Lobes in Sierra Nevada (Southern Spain ): Morphometry and Palaeoenvironmental Changes. Proc. Ninth Int. Conf. Permafr. 1321-1326.

Oliva, M., 2009. Holocene alpine environments in Sierra Nevada (southern Spain). University of Barcelona.

Oliva, M., Gómez-Ortiz, A., Schulte, L., 2010. Tendencia a la aridez en Sierra Nevada desde el holoceno medio inferida a partir de sedimentos lacustres. Increasing Arid. Sierra Nevada since Mid-Holocene inferred from lake sediments. Boletín de la Asociación de Geógrafos Españoles, (52) 27-42.

Oliva, M., Schulte, L., Ortiz, A.G., 2011. The role of aridification in constraining the elevation range of Holocene solifluction processes and associated landforms in the periglacial belt of the Sierra Nevada (southern Spain). Earth Surf. Process. Landforms 36, 1279-1291. https://doi.org/10.1002/esp.2116

Oliva, M., Gómez-Ortiz, A., 2012. Late-Holocene environmental dynamics and climate variability in a Mediterranean high mountain environment (Sierra Nevada, Spain) inferred from lake sediments and historical sources. Holocene 22, 915-927. https://doi.org/10.1177/0959683611434235

Oliva, M., Gómez-Ortiz, A., Salvador, F., Ramos, M., Palacios, D., Pereira, P., 2016. Inexistence of permafrost at the Veleta peak (Sierra Nevada). Science of Total Environment 550, 484-494. https://doi.org/10.1016/j.scitotenv.2016.01.150

Oliva, M., Žebre, M., Guglielmin, M., Hughes, P.D., Çiner, A., Vieira, G., Bodin, X., Andrés, N., Colucci, R.R., García-Hernández, C., Mora, C., Nofre, J., Palacios, D., Pérez-Alberti, A., Ribolini, A., Ruiz-Fernández, J., Sarıkaya, M.A., Serrano, E., Urdea, P., Valcárcel, M., Woodward, J.C., Yıldırım, C., 2018. Permafrost conditions in the Mediterranean region since the Last Glaciation. Earth-Science Rev. 185, 397-436. https://doi.org/10.1016/j.earscirev.2018.06.018

Oliva, M., Palacios, D., Fernández-Fernández, J.M., Rodríguez-Rodríguez, L., GarcíaRuiz, J.M., Andrés, N., Carrasco, R.M., Pedraza, J., Pérez-Alberti, A., Valcárcel, M., Hughes, P.D., 2019. Late Quaternary glacial phases in the Iberian Peninsula. Earth-Science Reviews 192, 564-600. https://doi.org/10.1016/j.earscirev.2019.03.015.

Oliva, M.; Gómez-Ortiz, A.; Vidal, J.; Salvador-Franch, F.; Salvà-Catarineu, M. 2015. El martillo de Schmidt como un instrumento de datación relativa. Aplicación preliminar a los arcos morrénicos del Corral del Veleta y Hoya del Mulhacén (Sierra Nevada). In: Gómez-Ortiz, A.; Salvador-Franch, F.; Oliva, M. \& SalvàCatarineu, M. (eds.). Avances, métodos y técnicas en el estudio del periglaciarismo. Publicacions i Edicions de la Universitat de Barcelona, Barcelona, pp. 323-331.

Oliva, M., Gómez-Ortiz, A., Palacios, D., Salvador-Franch, F., Andrés, N., Tanarro, L. M., Fernández-Fernández, J.M., Barriocanal, C. 2020. Multiproxy reconstruction of Holocene glaciers in Sierra Nevada (south Spain). Mediterranean Geoscience Reviews, 1-15. https://doi.org/10.1007/s42990-019-00008-2

Oskin, M., Burbank, D. W. 2005. Alpine landscape evolution dominated by cirque retreat. Geology, 33(12), 933-936. https://doi.org/10.1130/G21957.1

Paasche, Ø., Dahl, S. O., Bakke, J., Løvlie, R., \& Nesje, A. 2007. Cirque glacier activity in arctic Norway during the last deglaciation. Quaternary Research, 68(3), 387399. https://doi.org/10.1016/j.yqres.2007.07.006

Palacios, D., Marcos, J. Vázquez-Selem, L. 2011. Last Glacial Maximum and Deglaciation of Sierra de Gredos, Central Iberian Peninsula. Quaternary 
International, 233: 16-26. https://doi.org/10.1016/j.quaint.2010.04.029.

Palacios D, de Andrés N, de Marcos J, Vázquez-Selem L., 2012a. Glacial landforms and their palaeoclimatic significance in Sierra de Guadarrama, Central Iberian Peninsula. Geomorphology 139-140, 67-78. https://doi.org/10.1016/j.geomorph.2011.10.003.

Palacios D, Andrés N, Marcos J, Vázquez-Selem L., 2012b. Maximum glacial advance and deglaciation of the Pinar Valley (Sierra de Gredos, Central Spain) and its significance in the Mediterranean context. Geomorphology 177-178, 51-61. https://doi.org/10.1016/j.geomorph.2012.07.013

Palacios, D., Gómez-Ortiz, Andres, N., Salvador, F., Oliva, M. 2016. A Timing and new geomorphological evidence of the last deglaciation stages in Sierra Nevada (southern Spain) Quaternary Science Reviews 150, 110-129 https://doi.org/10.1016/i.quascirev.2016.08.012

Palacios, D., García-Ruiz, J.M., Andrés, N., Schimmelpfennig, I., Campos, N. Leanni, L., ASTER Team, 2017a. Deglaciation in the central Pyrenees during the Pleistocene-Holocene transition: Timing and geomorphologicalal significance. Quaternary Science Reviews 162, 111-127. https://doi.org/10.1016/j.quascirev. 2017.03.007

Palacios D., Andrés N., Gòmez-Ortiz A. \& García-Ruiz G. 2017b. Evidence of glacial activity during the Oldest Dryas in the Mountain of Spain. In: Hughes P. and Woodward J. Quaternary glaciation in the Mediterranean Mountains. Geological Society of London, Special Publication, 433(1), 87-110 https://doi.org/10.1144/SP433.10

Palacios, D., Gómez-Ortiz, A., Alcalá-Reygosa, J., Andrés, N., Oliva, M., Tanarro, L., Salvador-Franch, F., Schimmelpfennig, I., Fernández-Fernández, J.M., Léanni, L., 2019. The challenging application of cosmogenic dating methods in residual glacial landforms: The case of Sierra Nevada (Spain). Geomorphology 325, 103118. https://doi.org/10.1016/j.geomorph.2018.10.006.

Pallàs, R., Rodés, A., Braucher, R., Carcaillet, J., Ortuño, M., Bordonau, J., Bourlès, D., Vilaplana, J.M., Masana, E., Santanach, P., 2006. Late Pleistocene and Holocene glaciation in the Pyrenees: A critical review and new evidence from ${ }^{10} \mathrm{Be}$ exposure ages, south-central Pyrenees. Quaternary Science Reviews 25, 2937-2963. https://doi.org/10.1016/i.quascirev.2006.04.004.

Pallàs, R., Rodés, A., Braucher, R., Bourlès, D., Delmas, M., Calvet, M., Gunnell, Y., 2010. Small, isolated glacial catchments as priority targets for cosmogenic surface exposure dating of Pleistocene climate fluctuations, southeastern Pyrenees. Geology 38 (10), 891-894. https://doi.org/10.1130/G31164.1.

Palma, P., Oliva, M., García-Hernández, C., Ortiz, A. G., Ruiz-Fernández, J., SalvadorFranch, F., \& Catarineu, M. 2017. Spatial characterization of glacial and periglacial landforms in the highlands of Sierra Nevada (Spain). Science of the Total Environment, 584, 1256-1267. https://doi.org/10.1016/j.scitotenv.2017.01.196

Rasmussen, S.O., Bigler, M., Blockley, S.P., Blunier, T., Buchardt, S.L., Clausen, H. B., Cvijanovic, I., Dahl-Jensen, D., Johnsen, S.J., Fischer, H., Gkinis, V., Guillevic, M., Hoek, W.Z., Lowe, J.J., Pedro, J.B., Popp, T., Seierstad, I.K., Steffensen, J.P., Svensson, A.M., Vallelonga, P., Vinther, B.M., Walker, M.J.C., Wheatley, J.J., Winstrup, M. 2014. A stratigraphic framework for abrupt climatic changes during the Last Glacial period based on three synchronized Greenland icecore records: Refining and extending the INTIMATE event stratigraphy. Quat. Sci. Rev. 106, 14-28. https://doi.org/10.1016/j.quascirev.2014.09.007 
Renssen, H., Seppä, H., Heiri, O., Rotche, D. M., Goosse, H., \& Fichefet, T. 2009. The spatial and temporal complexity of the Holocene thermal maximum. Nature Geoscience, 2(6), 411. https://doi.org/10.1038/NGEO513

Ribolini, A., Chelli, A., Guglielmin, M., Pappalardo, M., 2007. Relationships between glacier and rock glacier in the Maritime Alps, Schiantala Valley, Italy. Quat. Res. 68, 353-363. https://doi.org/10.1016/j.yqres.2007.08.004

Rodríguez-Rodríguez, L., Jiménez-Sánchez, M., Domínguez-Cuesta, M. J., Rinterknecht, V., Pallas, R., \& Bourles, D. 2016. Chronology of glaciations in the Cantabrian Mountains (NW Iberia) during the Last Glacial Cycle based on in situproduced ${ }^{10} \mathrm{Be}$. Quaternary Science Reviews, 138, 31-48. https://doi.org/10.1016/j.quascirev.2016.02.027

Rodríguez-Rodríguez, L., Jiménez-Sánchez, M., Domínguez-Cuesta, M.J., Rinterknecht, V., Pallàs, R., Aster Team, 2017. Timing of last deglaciation in the Cantabrian Mountains (Iberian Peninsula; North Atlantic region) based on in situproduced ${ }^{10} \mathrm{Be}$ exposure dating. Quat. Sci. Rev. 171, 166-181. https://doi.org/10.1016/j.quascirev.2017.07.012

Sanders, J.W., Cuffey, K.M., Moore, J.R., MacGregor, K.R., Kavanaugh, J.L., 2012. Periglacial weathering and headwall erosion in cirque glacier bergschrunds. Geology 40 (9),779-782. https://doi.org/10.1130/G33330.1

Sanders, J.W., Cuffey, K.M.,MacGregor, K.R., Collins, B.D., 2013. The sediment budget of an alpine cirque. Geol. Soc. Am. Bull. 125, 229-248. https://doi.org/10.1130/B30688.1

Sarıkaya, M. A., Çiner, A., Yıldırım, C., 2017. Cosmogenic ${ }^{36} \mathrm{Cl}$ glacial chronologies of the Late Quaternary glaciers on Mount Geyikdağ in the Eastern Mediterranean. Quaternary Geochronology 39, 189-204. https://doi.org/10.1016/j.quageo.2017.03.003

Serrano, E., Oliva, M., González-García, M., López-Moreno, J.I., González-Trueba, J., Martín-Moreno, R., Gómez-Lende, M., Martín-Díaz, J., Nofre, J., Palma, P., 2018. Post-little ice age paraglacial processes and landforms in the high Iberian mountains: A review. L. Degrad. Dev. 29, 4186-4208. https://doi.org/10.1002/1dr.3171

Styllas, M. N., Schimmelpfennig, I., Benedetti, L., Ghilardi, M., Aumaître, G., Bourlès, D., Keddadouche, K., 2018. Late-glacial and Holocene history of the northeast Mediterranean mountain glaciers-New insights from in situ-produced ${ }^{36} \mathrm{Cl}$-based cosmic ray exposure dating of palaeo-glacier deposits on Mount Olympus, Greece. Quaternary Science Reviews 193, 244-265. https://doi.org/10.1016/j.quascirev.2018.06.020

Tanarro, L. M., Fernández, J.M., Andres, N., Zamorano, JJ., Sæmundsson, P., Brynjólfsson, S., Palacios, D. 2019. Unchanged surface morphology of debriscovered glacier and rock glaciers in Tröllaskagi Peninsula (Northern Iceland). Science of the Total Environment 648, 218-235 https://doi.org/10.1016/j.scitotenv.2018.07.460

Tomkins, M. D., Dortch, J. M., Hughes, P. D., Huck, J. J., Stimson, A. G., Delmas, M., ... \& Pallàs, R. 2018. Rapid age assessment of glacial landforms in the Pyrenees using Schmidt hammer exposure dating (SHED). Quaternary Research, 90(1), 2637. https://doi.org/10.1017/qua.2018.12

Uppala, S.M., Kållberg, P., Simmons, A., Andrae, U., Bechtold, V., Fiorino, M., Gibson, J., Woollen, J., 2005. The ERA-40 reanalysis. Q.J.R. Meteorol. Soc. 131, 2961-3012. https://doi.org/10.1256/qj.04.176

Walker, M., Johnsen, S., Rasmussen, S. O., Popp, T., Steffensen, J. P., Gibbard, P., ... \& 
Cwynar, L. C. (2009). Formal definition and dating of the GSSP (Global Stratotype Section and Point) for the base of the Holocene using the Greenland NGRIP ice core, and selected auxiliary records. Journal of Quaternary Science, 24(1), 3-17. https://doi.org/10.1002/jqs. 1227

Zahno, C., Akçar, N., Yavuz, V., Kubik, P. W., \& Schlüchter, C. 2010. Chronology of late Pleistocene glacier variations at the Uludağ Mountain, NW Turkey. Quaternary Science Reviews, 29(9-10), 1173-1187. https://doi.org/10.1016/j.quascirev.2010.01.012

Zasadni, J., Kłapyta, P., Broś, E., Ivy-Ochs, S., Świąder, A., Christl, M., \& Balážovičová, L. 2020. Latest Pleistocene glacier advances and post-Younger Dryas rock glacier stabilization in the Mt. Kriván group, High Tatra Mountains, Slovakia. Geomorphology, 107093. https://doi.org/10.1016/j.geomorph.2020.107093

Žebre, M., Sarıkaya, M. A., Stepišnik, U., Yıldırım, C., \& Çiner, A. 2019. First ${ }^{36} \mathrm{Cl}$ cosmogenic moraine geochronology of the Dinaric mountain karst: Velež and Crvanj Mountains of Bosnia and Herzegovina. Quaternary Science Reviews, 208, 54-75. https://doi.org/10.1016/j.quascirev.2019.02.002 
1277 Table 1. Field data of sampling sites, topographic shielding factor, sample thickness and

1278 distance from the headwall.

1279 Table 2. Analytical data and cosmic-ray exposure (CRE) ages. ${ }^{10} \mathrm{Be} /{ }^{9} \mathrm{Be}$ ratios were 1280 measured at the ASTER AMS facility. The numbers in italics correspond to the internal 1281 (analytical) uncertainty at $1 \sigma$ level.

1282 Table 3. Location, main topographic characteristics, geomorphologicalal units, and 1283 average CRE ages from the cirques studied in the Sierra Nevada compared to the 1284 Mulhacén cirque.

1285 Table 4. Location, main topographic characteristics, geomorphologicalal units, and 1286 average CRE ages of the cirques studied in the rest of Iberian Peninsula (outside Sierra 1287 Nevada). All CRE ages are updated following Oliva et al. (2019).

1288 Table 5. Location, main topographic characteristics, geomorphologicalal units, and 1289 average CRE ages of the cirques studied in the Mediterranean region (Iberian Peninsula 1290 not included). All CRE ages are updated.

1291 Table 6. Location, main topographic characteristics, geomorphologicalal units, and 1292 average CRE ages of the cirques studied in the Central European region (outside Sierra 1293 Nevada). All CRE ages are updated.

1294 Table 7. Location, main topographic characteristics, geomorphologicalal units, and 1295 average CRE ages of the cirques studied in the British Isles and Iceland. All CRE ages 1296 are updated.

1297 Table 8. Location, main topographic characteristics, geomorphologicalal units, and 1298 average CRE ages of the cirques studied in the Western North America. All CRE ages 1299 are updated. 
1302 Figure 1. Location map of the study area. A) Location of the Sierra Nevada in the context 1303 of the Iberian Peninsula. B) Glacier extent of the Sierra Nevada glaciers during their 1304 LLGM. C) Western sector of the Sierra Nevada where the main peaks and the cirques 1305 cited throughout the text are distributed.

1306 Figure 2. Mulhacén cirque and location of the CRE sampling sites and ${ }^{10}$ Be ages. A) 1307 Aerial orthophoto. B) Geomorphological map.

1308 Figure 3. Geomorphological transect along the Mulhacén cirque (S-N direction) showing 1309 the ${ }^{10} \mathrm{Be}$ CRE ages (in ka).

1310 Figure 4. Photos of the Mulhacén cirque floor, with the location of the CRE sampling 1311 sites and ${ }^{10} \mathrm{Be}$ ages. Panels $\mathrm{A}$ ) and B) are oblique views of La Mosca Lake taken from the 1312 SE and E, respectively.

1313 Figure 5. Photos of the Mulhacén cirque floor, location of the CRE sampling sites and $1314{ }^{10}$ Be CRE ages. A) Oblique view of La Mosca Lake from the W. B) Blocky moraine 1315 where the sample MOSCA-5 (with nuclide inheritance) was collected.

1316 Figure 6. CRE age correlation with: A) elevation, and B) distance to the Mulhacén 1317 headwall. In the panel B) we have removed the sample MOSCA-5 as being an outlier 1318 (cosmogenic nuclide inheritance). In the panel A) the correlation with altitude is very 1319 weak as all the samples are located on the flat floor of the cirque.

1320 Figure 7. Probability density plots of CRE ages for different chronostratigraphic units in 1321 the A) Mulhacén cirque (data shown in Table 3) and B) in the Sierra Nevada cirques (data 1322 shown in Table 4). Panels correspond to different stages according to the 1323 chronostratigraphy: a) Deglaciation of the Mulhacén cirque floor after the Younger 1324 Dryas. b) Deglaciation of the cirque mouth at the beginning of the Bølling-Allerød 1325 interstadial. We have included two outlier samples, probably with cosmogenic nuclide 1326 inheritance (MOSCA-5 and MOSCA-7). The number associated with each averaged CRE 1327 age refers to the number of CRE ages from each geomorphological unit considered. We 1328 assume that this average is indicative of the age for each geomorphological phase detected 1329 in each cirque.

1330 Figure 8. Synthetic evolution model of the deglaciation phases in the cirques of the Sierra 1331 Nevada. A) The glaciers filled the cirques during the OD, until just before the onset of 
1332 the B-A Interstadial. B) The mouth of most of the cirques was deglaciated during the B-

1333 A Interstadial. C) Glaciers might have disappeared from the Sierra Nevada cirques. D)

1334 Most of the cirques hosted new small glaciers during the YD. After this phase, the cirques

1335 evolved differently, according to their topographic characteristics. E.1) Cirques with

1336 summits at 3000-3200 m and floors at $>2800 \mathrm{~m}$, with small headwalls $(<200 \mathrm{~m}$ of altitude

1337 range) and east-facing produced only small proto-rock glaciers. E.2) Cirques with

1338 summits at $3000-3200 \mathrm{~m}$ and floors at $>2800 \mathrm{~m}$, with steep and long headwalls $(>300 \mathrm{~m}$

1339 of altitude range) developed larger rock glacier complexes, especially if they are north

1340 facing. E.3) Cirques with summits at $<3000 \mathrm{~m}$ and floors at $<2800 \mathrm{~m}$. The shrinking

1341 glaciers left one or more moraines - or even none - depending on the intensity of the

1342 paraglacial readjustment of their surrounding walls. Cirques with summits at $>3300 \mathrm{~m}$

1343 and floors at $>2950 \mathrm{~m}$, north-facing and with $>300$-m-high walls recorded geomorphic

1344 evidence from glacier changes from the YD to present. This is the case of the Veleta and

1345 Mulhacén cirques, but their evolution was different. E.4) Veleta palaeoglacier formed

1346 only a large polygenic moraine. E.5) Mulhacén palaeoglacier developed a sequence of

1347 moraine ridges.

1348 Figure 9. Probability density plots of CRE ages for different chronostratigraphical units

1349 in A) The Iberian Peninsula cirques (data shown in Table 4); B) The Mediterranean

1350 cirques (outside Iberian Peninsula) (data shown in Table 5); C) The Central European

1351 cirques (data shown in Table 6); D) The British Isles and Iceland cirques; E) The Western

1352 North America cirques (data shown in Table 8); F) Rock glacier front stabilization in the

1353 cirques analysed in the North Hemisphere (data shown in Tables 3, 4, 5, 6, 7 and 8). For

1354 Figure 9, B), C), D) and E) the plots are clustered in a) Deglaciation of the cirque floor

1355 after the YD (ages of the stabilization of the youngest moraine and polished bedrock

1356 surfaces); b) Deglaciation of the mouth of the cirque, at the beginning of the B-A

1357 Interstadial (ages of the stabilization of the oldest moraine inside the cirque and polished

1358 bedrock surfaces). For the Panel F) the plots are clustered in a) Rock glacier front

1359 stabilization after Neoglacial advances; b) Rock glacier front stabilization after the

1360 Younger Dryas; c) Rock glacier front stabilization after at the beginning of the B-A

1361 Interstadial. The number associated with each averaged CRE age refers to the number of

1362 CRE ages from each geomorphological unit considered.

1363 Figure 10. Probability density plots of CRE ages for different chronostratigraphical units, 1364 comparing all the results from the six regions. The plots are clustered in a) Rock glacier 
1365 front stabilization after the YD; b) Deglaciation of the cirque floor after the YD (ages of 1366 the stabilization of the youngest moraine and polished bedrock surfaces); c) Deglaciation 1367 of the mouth of the cirque, at the beginning of the B-A Interstadial (ages of the 1368 stabilization of the oldest moraine inside the cirque and polished bedrock surfaces). The 1369 number associated with each averaged CRE age refers to the number of cirques with 1370 available CRE ages in a given region analysed. The average CRE age of each 1371 geomorphological unit is compared with the Greenland ice core chronology (Rasmussen 1372 et al., 2014).

1373 

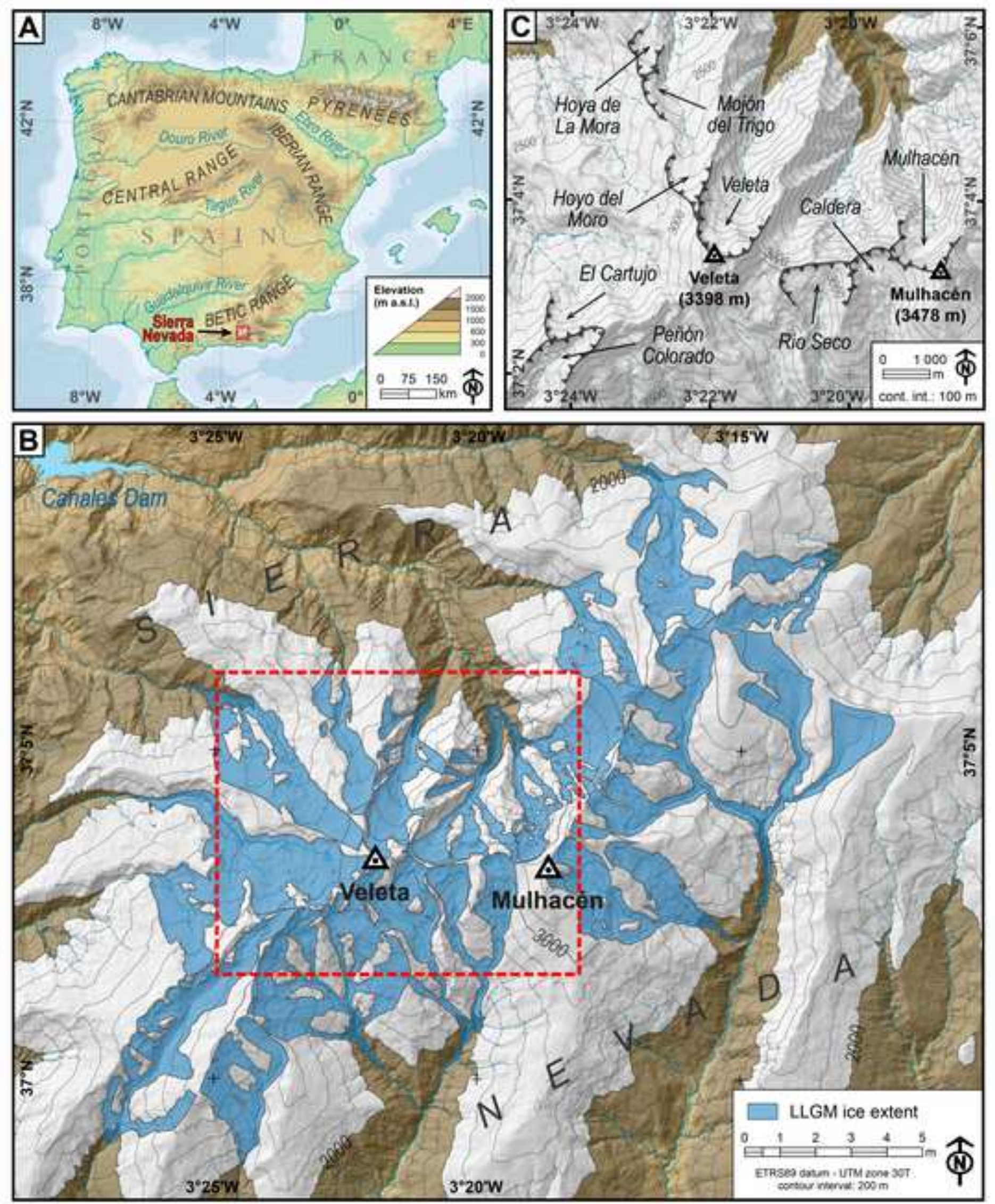

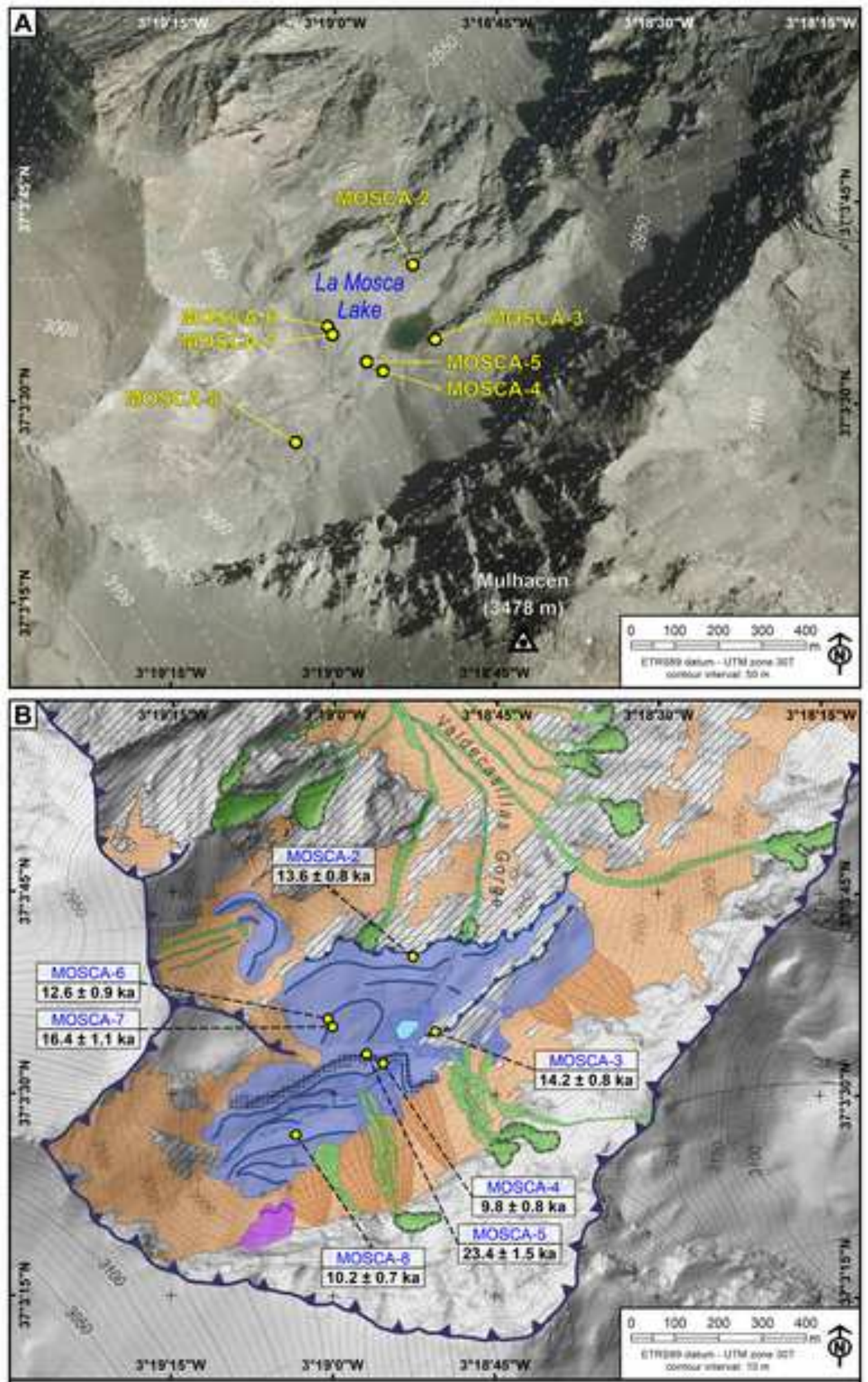

\section{Legend}

\begin{tabular}{|c|c|c|c|}
\hline O Be sample & Blocky moraine & Talus scree & Cirque wall \\
\hline [. Glacial cirque & Till & $\square$ Talus cone & $D$ Bedrock \\
\hline Threshold & $\square$ Protalus lobe & 5 Debris flow & - - Stream \\
\hline
\end{tabular}




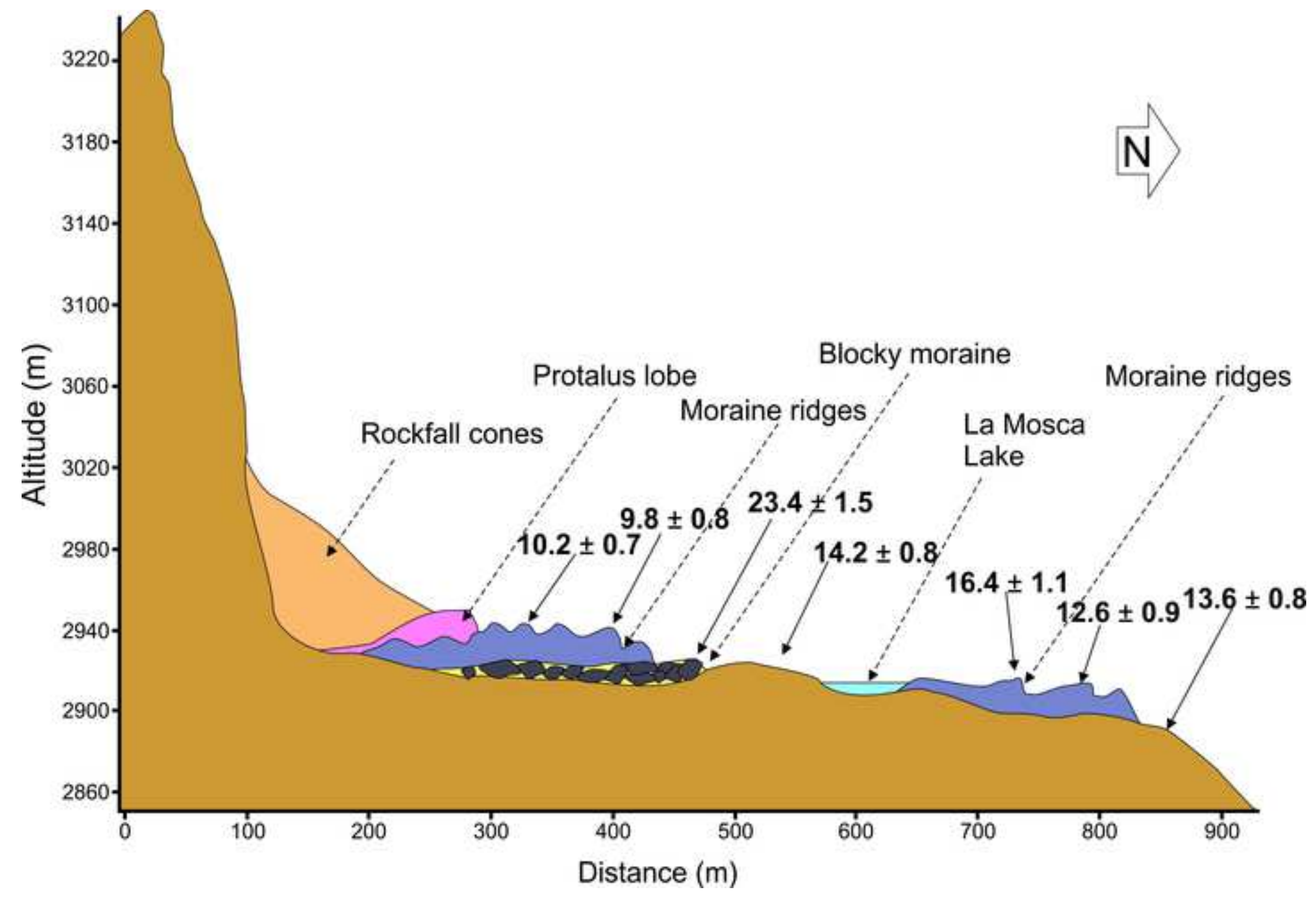




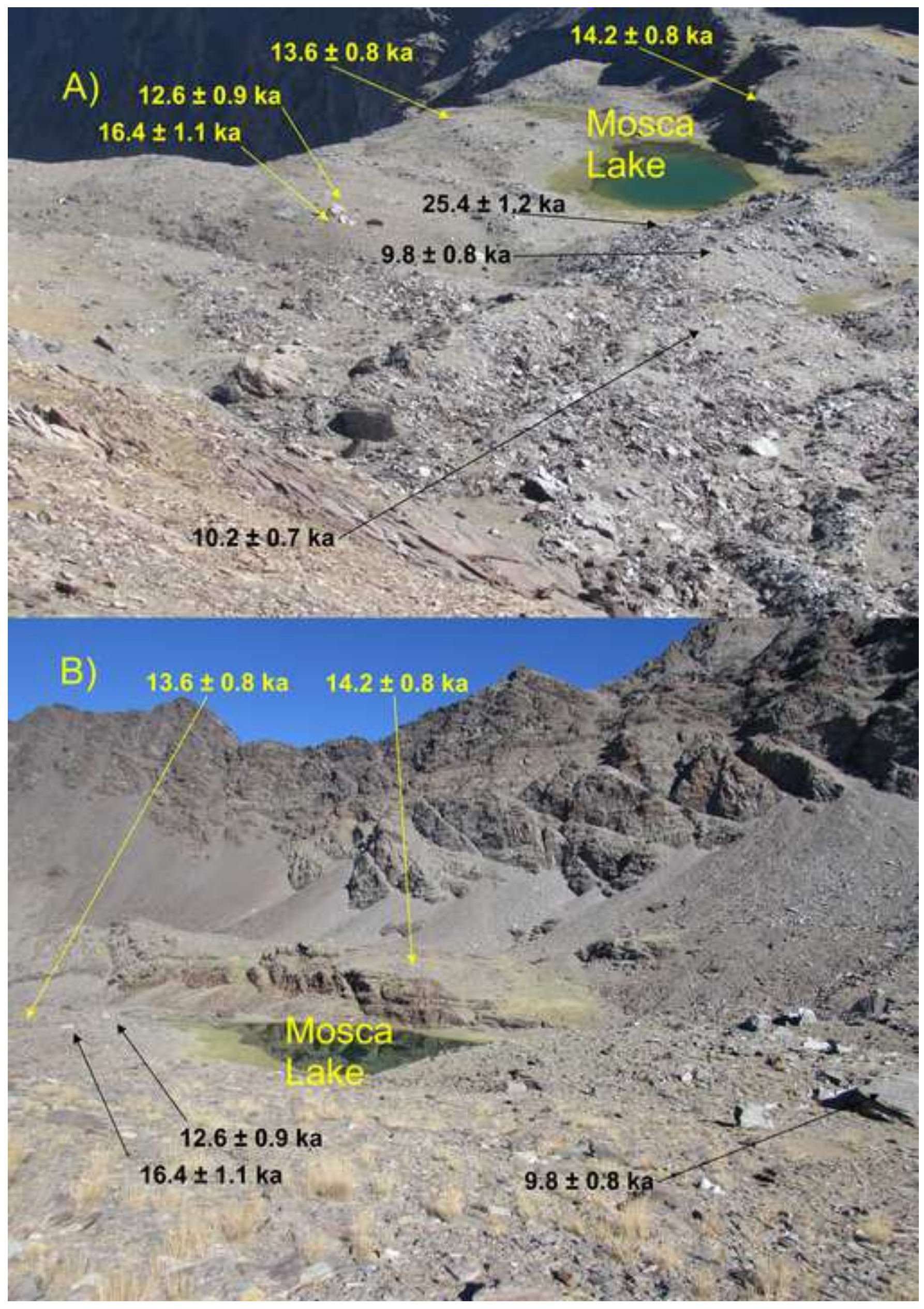




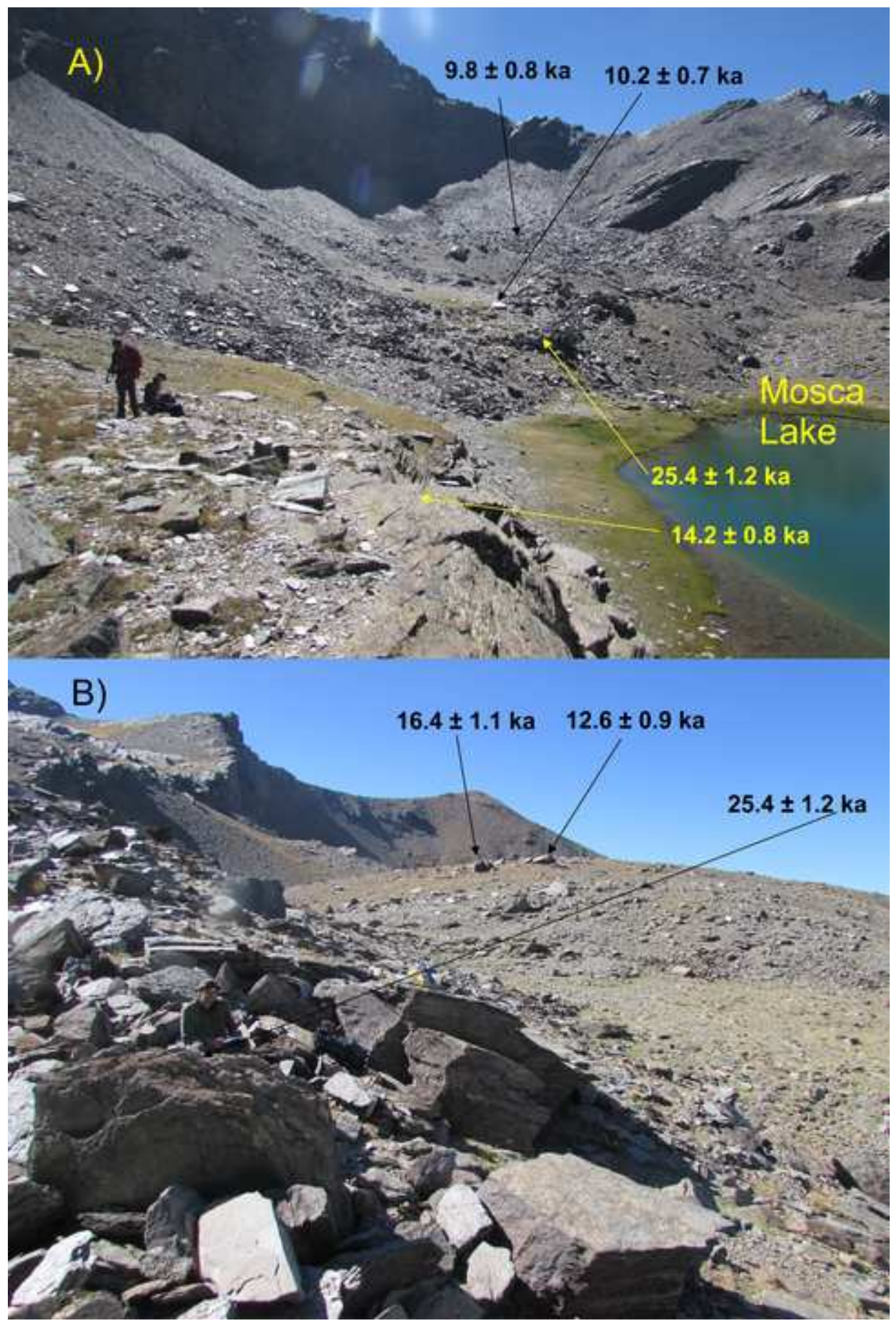



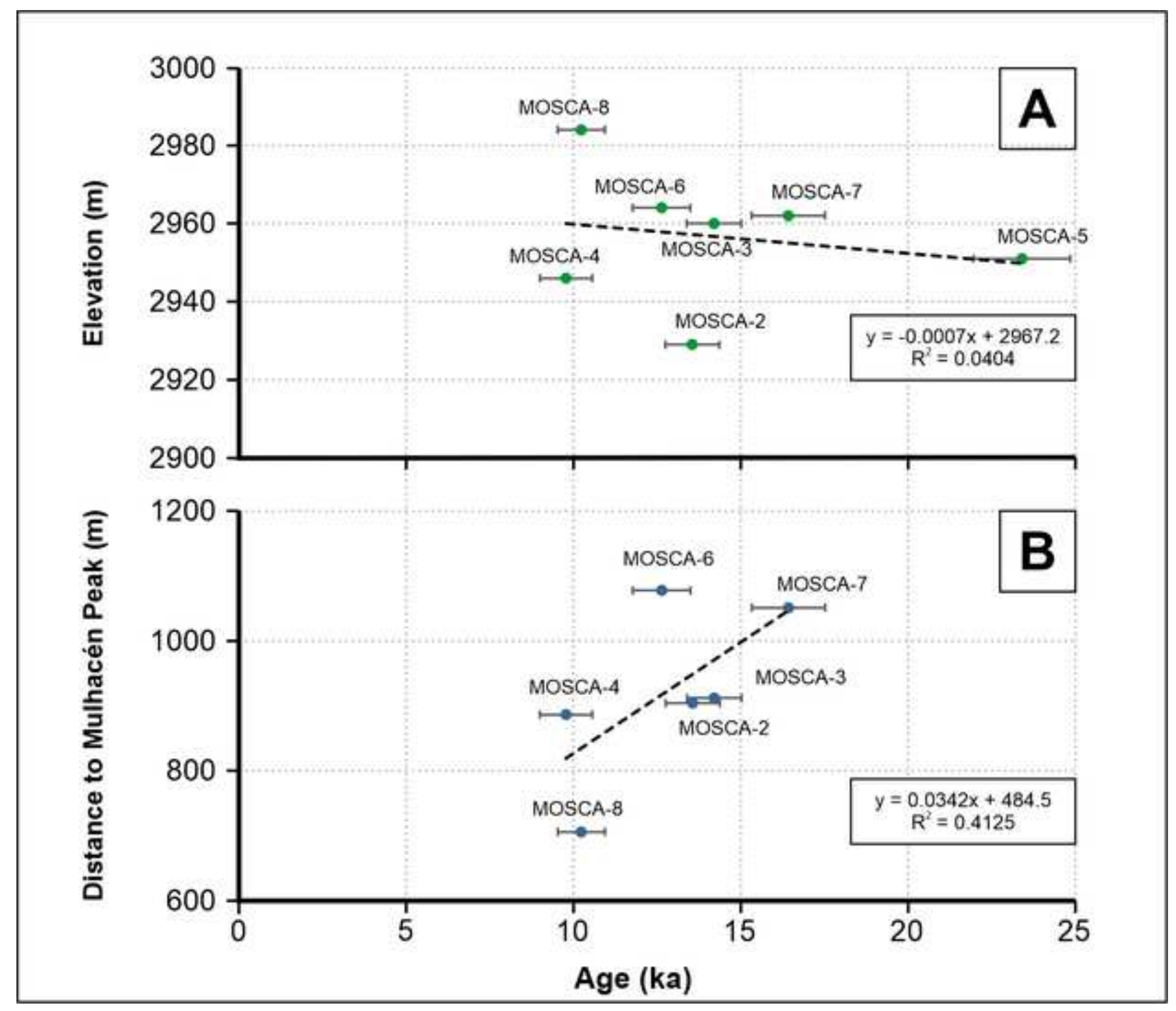


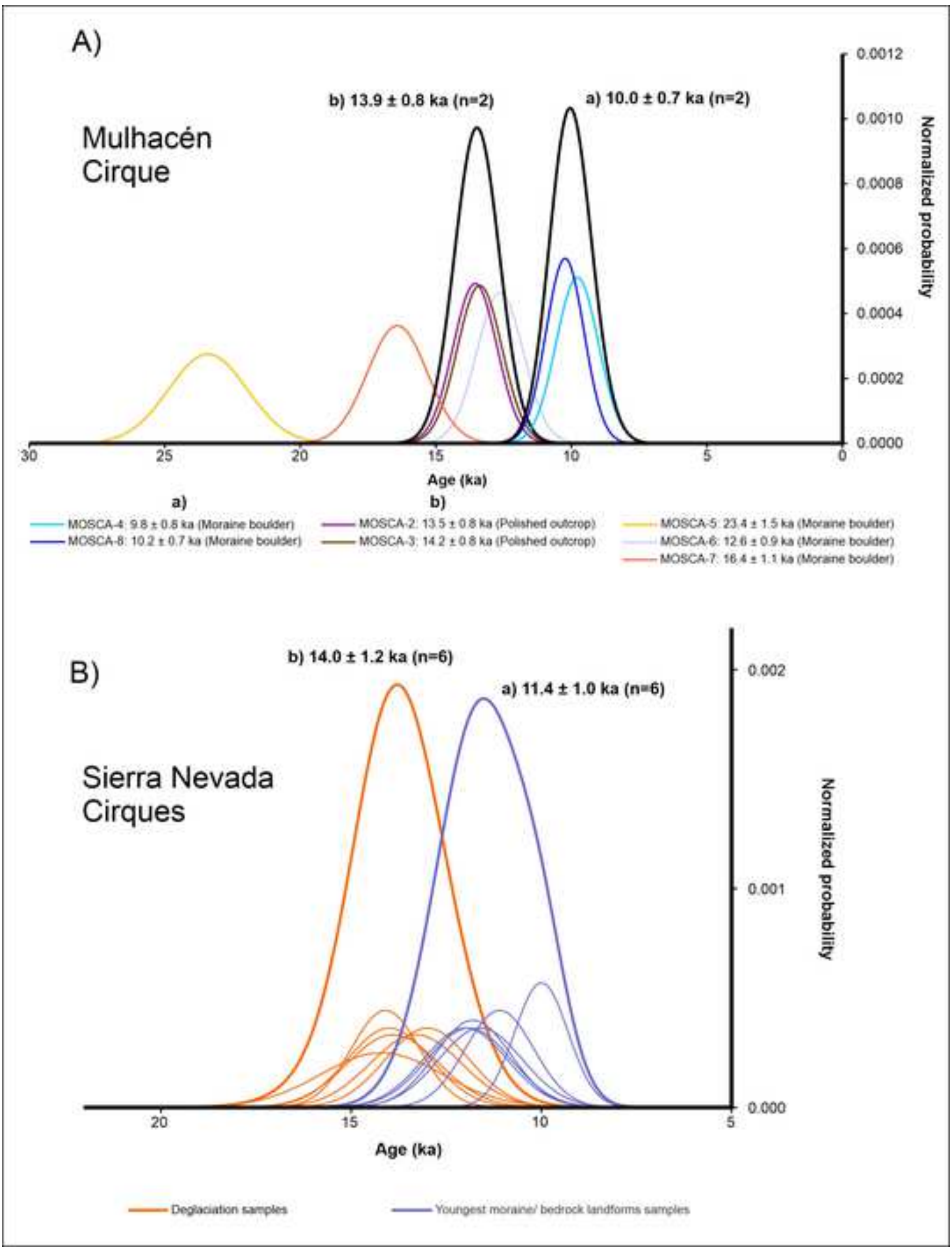



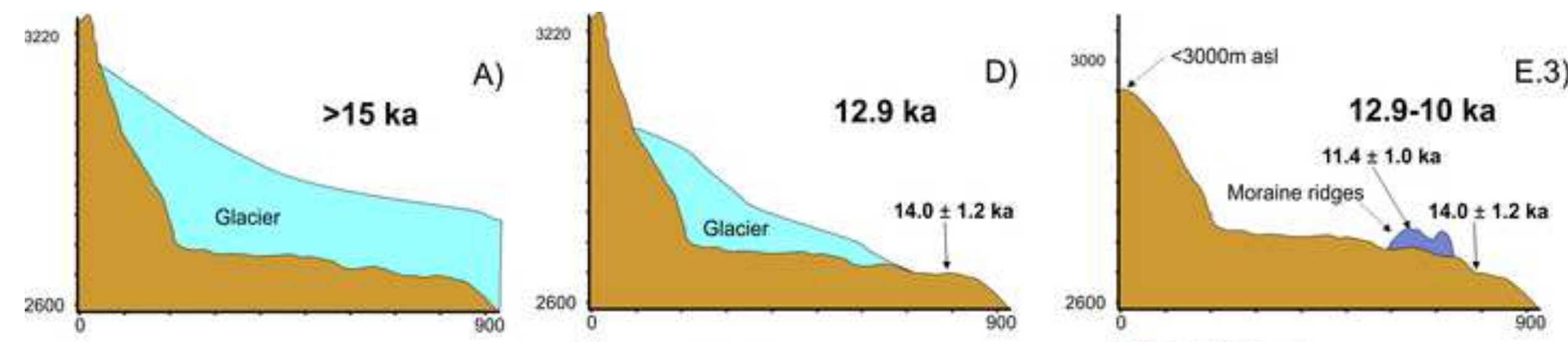

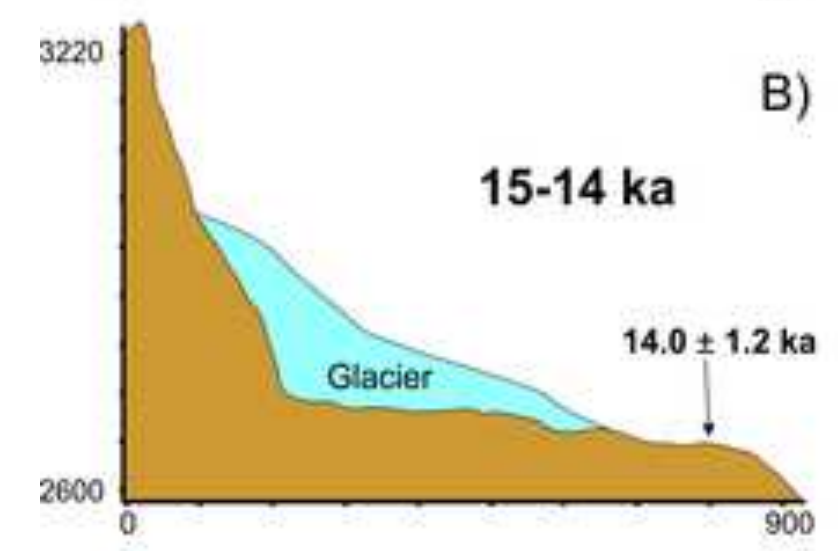

sot
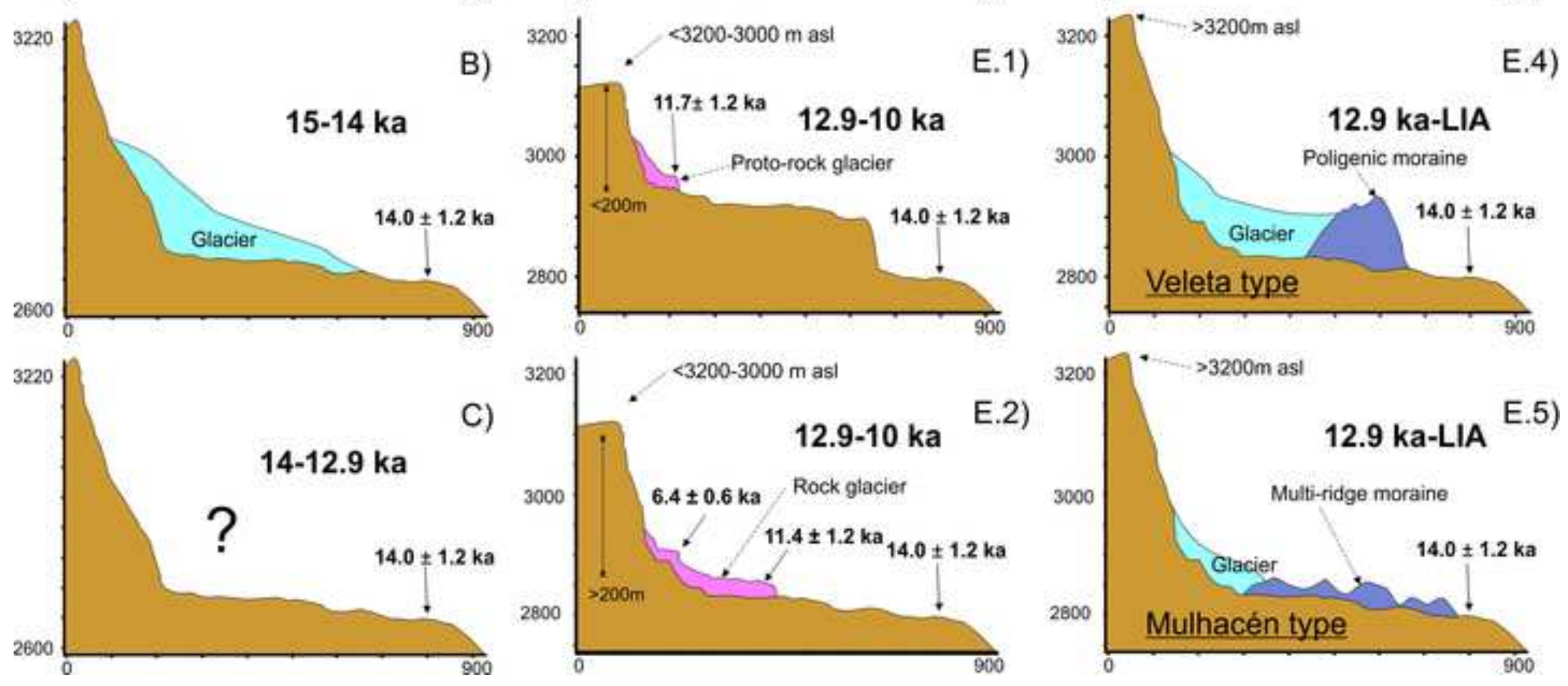


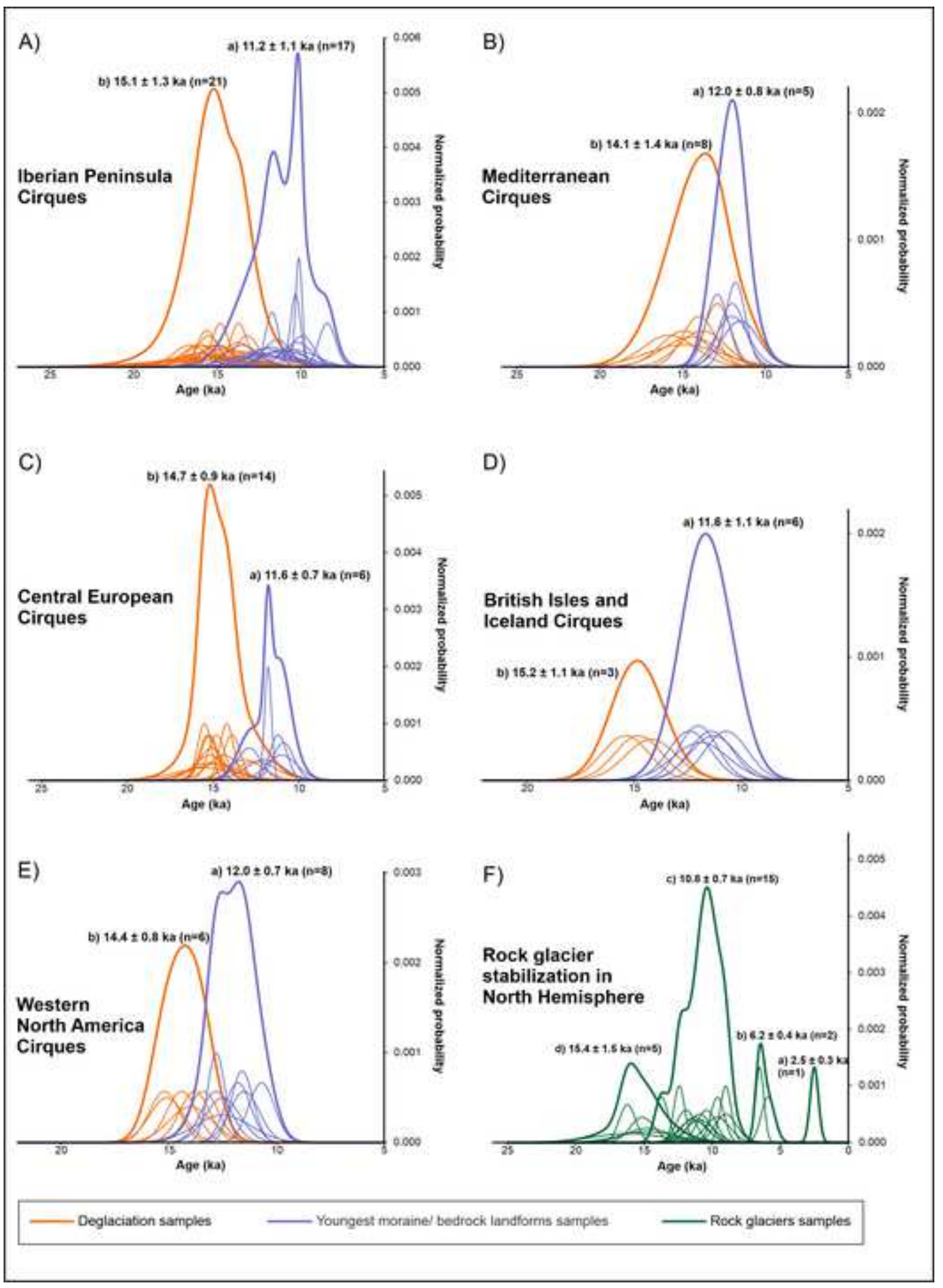




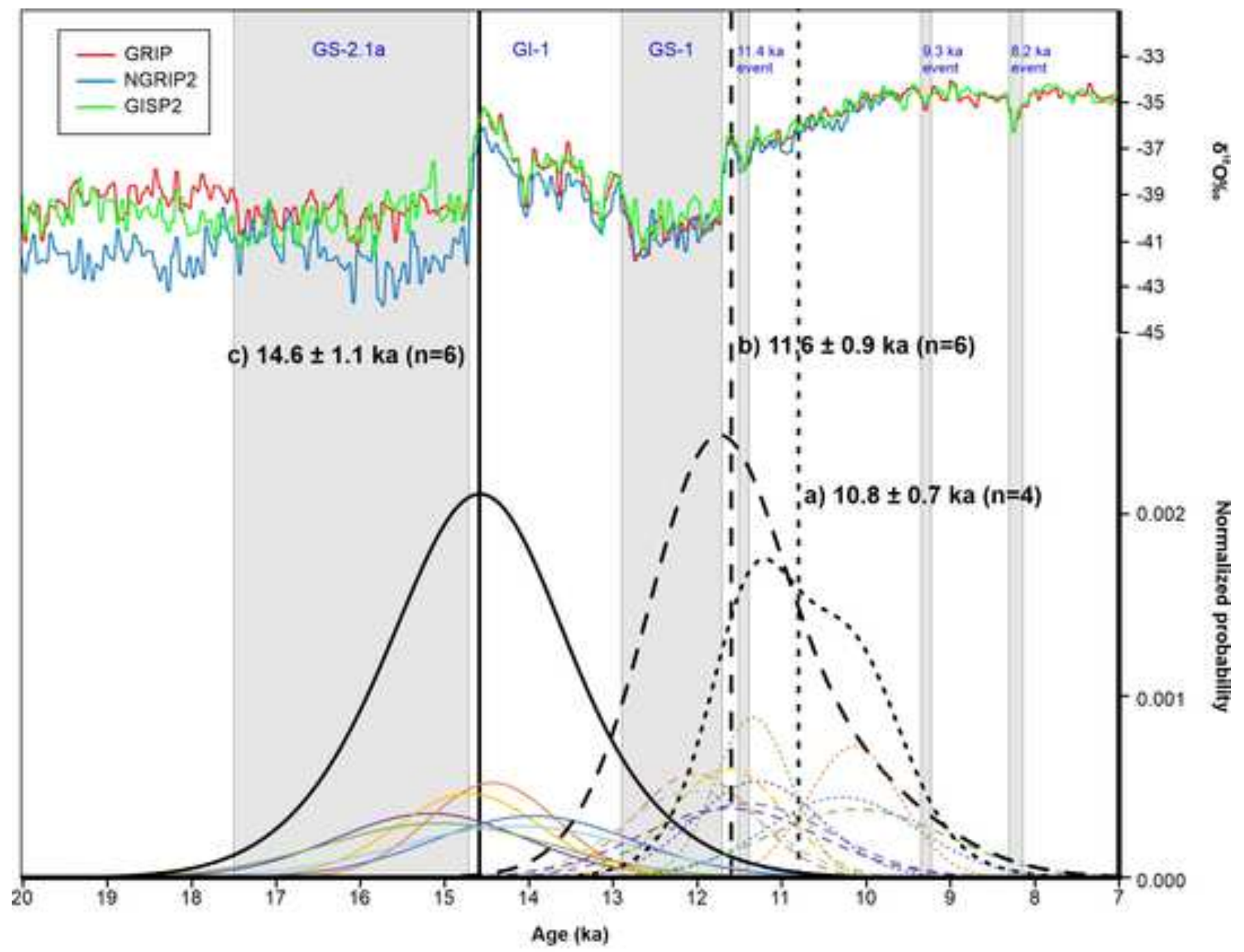

\begin{tabular}{|c|c|c|c|}
\hline & $\begin{array}{l}\text { Deglaciation of } \\
\text { the cirque }\end{array}$ & $\begin{array}{l}\text { Youngest moraine/ } \\
\text { bedrock }--\end{array}$ & $\begin{array}{l}\text { Rock glacier } \\
\text { landforms ..... }\end{array}$ \\
\hline Sierra Nevada & - & $m-\infty+\cdots$ & 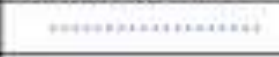 \\
\hline berian Peninsuia & E & $\ldots \ldots$ & 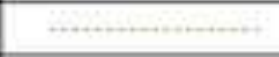 \\
\hline Mediterranean region & - & $+\ldots+\cdots+\cdots$ & \\
\hline Central European region & 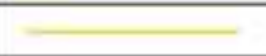 & $\ldots+\cdots \cdots+\cdots$ & \\
\hline British Isles and Subpolar regions & $\longrightarrow$ & 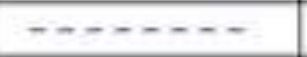 & 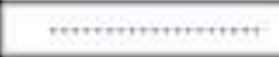 \\
\hline Western North America & $\overline{-}$ & $\ldots \cdots$ & 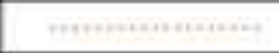 \\
\hline
\end{tabular}


Table 1. Field data of sampling sites, topographic shielding factor, sample thickness and distance from the headwall.

\begin{tabular}{|c|c|c|c|c|c|c|c|}
\hline Sample name & Sample type & Latitude (DD) & Longitude (DD) & $\begin{array}{l}\text { Elevation } \\
\text { (m a.s.l.) }\end{array}$ & $\begin{array}{c}\text { Topographic } \\
\text { shielding factor }\end{array}$ & $\begin{array}{l}\text { Thickness } \\
(\mathrm{cm})\end{array}$ & $\begin{array}{l}\text { Distance from the headwall }(\mathrm{m}) \text { : } \\
\text { map vs ground length }\end{array}$ \\
\hline MOSCA-2 & Polished outcrop & 37.06117 & -3.31463 & 2929 & 0.9757 & 3.0 & $904 / 1058$ \\
\hline MOSCA-3 & Polished outcrop & 37.05963 & -3.31405 & 2960 & 0.9545 & 2.0 & $911 / 1049$ \\
\hline MOSCA-4 & Moraine boulder & 37.05897 & -3.31539 & 2946 & 0.9579 & 2.5 & $886 / 1034$ \\
\hline MOSCA-5 & Moraine boulder & 37.05916 & -3.31581 & 2951 & 0.9579 & 2.5 & 932 / 1071 \\
\hline MOSCA-6 & Moraine boulder & 37.05989 & -3.31681 & 2964 & 0.9572 & 3.0 & 1077 / 1194 \\
\hline MOSCA-7 & Moraine boulder & 37.05972 & -3.31669 & 2962 & 0.9579 & 4.0 & $1050 / 1170$ \\
\hline MOSCA-8 & Moraine boulder & 37.05749 & -3.31763 & 2984 & 0.9460 & 4.0 & $706 / 862$ \\
\hline
\end{tabular}


Table 2. Analytical data and cosmic ray exposure (CRE) ages. ${ }^{10} \mathrm{Be} /{ }^{9} \mathrm{Be}$ ratios were measured at the ASTER AMS facility. The numbers in italics correspond to the internal (analytical) uncertainty at $1 \sigma$ level.

\begin{tabular}{|c|c|c|c|c|c|c|c|}
\hline Sample name & $\begin{array}{l}\text { Quartz weight } \\
\text { (g) }\end{array}$ & $\begin{array}{l}\text { Mass of carrier } \\
\quad\left({ }^{9} \mathrm{Be} \mathrm{mg}\right)\end{array}$ & $\begin{array}{l}\text { ASTER cathode } \\
\text { ID }\end{array}$ & $\begin{array}{l}{ }^{10} \mathrm{Be} /{ }^{/} \mathrm{Be}\left(1^{-13}\right) \text { corrected } \\
\text { of chemical blank }\end{array}$ & $\begin{array}{c}\text { Blank correction } \\
(\%)\end{array}$ & {$\left[{ }^{10} \mathrm{Be}\right]\left(10^{4}\right.$ atoms $\left.\mathrm{g}^{-1}\right)$} & Age (ka) \\
\hline MOSCA-2 & 39.7779 & 155.9 & ICYQ & $4.7124 \pm 0.1461$ & 0.52 & $37.321 \pm 1.163$ & $13.55 \pm 0.8(0.4)$ \\
\hline MOSCA-3 & 29.2882 & 155.5 & ICYR & $3.6722 \pm 0.1148$ & 0.67 & $39.418 \pm 1.238$ & $14.20 \pm 0.8(0.4)$ \\
\hline MOSCA-5 & 5.9343 & 156.3 & ICYT & $1.2924 \pm 0.0571$ & 1.87 & $68.786 \pm 3.045$ & $23.41 \pm 1.5(0.9)$ \\
\hline MOSCA-6 & 40.4572 & 153.2 & ICYU & $4.5547 \pm 0.2008$ & 0.54 & $34.864 \pm 1.541$ & $12.63 \pm 0.9(0.5)$ \\
\hline MOSCA-7 & 21.5507 & 155.5 & ICYV & $3.1261 \pm 0.1501$ & 0.78 & $45.598 \pm 2.194$ & $16.42 \pm 1.1(0.7)$ \\
\hline MOSCA-8 & 40.1676 & 156.3 & ICYW & $3.5672 \pm 0.1130$ & 0.68 & $28.061 \pm 0.893$ & $10.23 \pm 0.7(0.4)$ \\
\hline \multicolumn{8}{|l|}{${ }^{10}$ Be Blank } \\
\hline MOSCA-BK & - & 157.8 & ICYP & & - & - & - \\
\hline
\end{tabular}


Table 3. Location, main topographic characteristics, geomorphological units, and average CRE ages from the cirques studied in the Sierra Nevada compared to the Mulhacén cirque.

\begin{tabular}{|c|c|c|c|c|c|c|c|c|c|c|}
\hline $\begin{array}{l}\text { Cirque/ } \\
\text { valley }\end{array}$ & Location $^{1}$ & $\begin{array}{c}\text { Cirque } \\
\text { elevation }^{\text {range }^{2}} \\
\text { (m a.s.l.) and } \\
\text { (m) } \\
\end{array}$ & $\begin{array}{l}\text { Length }^{3} \\
\text { (m) }\end{array}$ & Aspect $^{4}$ & $\begin{array}{l}\text { Deglaciation } \\
(\mathbf{k a})^{5}\end{array}$ & $\begin{array}{c}\text { Youngest } \\
\text { moraine/ } \\
\text { bedrock } \\
\text { (ka) }^{6}\end{array}$ & $\begin{array}{c}\text { Distance from } \\
\text { headwall to the } \\
\text { youngest } \\
\text { moraine }(\mathbf{m})^{7}\end{array}$ & $\begin{array}{c}\text { Rock glacier } \\
\text { and protalus } \\
\text { lobe landforms } \\
\text { (ka) }^{8}\end{array}$ & $\begin{array}{r}\text { Neoglacial } \\
\text { landforms } \\
(\mathrm{ka} / \mathrm{CE})^{9}\end{array}$ & References \\
\hline $\begin{array}{l}\text { La Mora/ } \\
\text { San Juan }\end{array}$ & $\begin{array}{l}37^{\circ} 5^{\prime} 43^{\prime \prime N} \\
3^{\circ} 22^{\prime} 57^{\prime \prime} \mathrm{W}\end{array}$ & $\begin{array}{l}2609-2350 \\
(259)\end{array}$ & 600 & $\mathrm{NE}$ & $\begin{array}{c}13.9 \pm 1.2 \\
(n=2)\end{array}$ & $\begin{array}{c}4 \text { moraine } \\
\text { ridges } \\
\mathbf{1 1 . 6} \pm \mathbf{1 . 1} \\
(\mathbf{n}=\mathbf{2})\end{array}$ & 400 & - & & $\begin{array}{c}\text { Palacios et al. } \\
\text { (2016) }\end{array}$ \\
\hline $\begin{array}{l}\text { Mojón del } \\
\text { Trigo/ San } \\
\text { Juan }\end{array}$ & $\begin{array}{l}37^{\circ} 5{ }^{\prime} 22^{\prime \prime} \mathrm{N} \\
3^{\circ} 22^{\prime} 36^{\prime \prime} \mathrm{W}\end{array}$ & $\begin{array}{l}2609-2350 \\
(259)\end{array}$ & 800 & $\mathrm{E}$ & $\begin{array}{c}14.5 \pm 1.2 \\
(n=2)\end{array}$ & $\begin{array}{l}3 \text { moraine } \\
\text { ridges } \\
\mathbf{1 1 . 8} \pm \mathbf{1 . 0} \\
(\mathbf{n}=\mathbf{2}) \\
\end{array}$ & 600 & - & & $\begin{array}{c}\text { Palacios et al. } \\
\text { (2016) }\end{array}$ \\
\hline $\begin{array}{l}\text { El Moro/ } \\
\text { San Juan }\end{array}$ & $\begin{array}{l}37^{\circ} 4^{\prime} 28^{\prime \prime N} \\
3^{\circ} 22^{\prime} 22^{\prime \prime} \mathrm{W}\end{array}$ & $\begin{array}{l}2925-2790 \\
(135)\end{array}$ & 700 & $\mathrm{E}$ & $\begin{array}{c}14.0 \pm 1.1 \\
(n=2)\end{array}$ & $\begin{array}{c}1 \text { ridge } \\
\mathbf{1 1 . 1} \pm \mathbf{0 . 9} \\
(\mathrm{n}=\mathbf{1})\end{array}$ & 500 & & & $\begin{array}{c}\text { Palacios et al. } \\
\text { (2016) }\end{array}$ \\
\hline $\begin{array}{l}\text { Cartujo/ } \\
\text { Dílar }\end{array}$ & $\begin{array}{c}37^{\circ} 3^{\prime} 9^{\prime \prime} \mathrm{N} \\
3^{\circ} 22^{\prime} 57^{\prime \prime} \mathrm{W}\end{array}$ & $\begin{array}{c}3152-2700 \\
\quad(452)\end{array}$ & 1400 & $\mathrm{~N}$ & $\begin{array}{c}14.2 \pm 1.6 \\
(n=2)\end{array}$ & No data & & $\begin{array}{c}\text { Rock glacier } \\
\text { From } \mathbf{1 1 . 4} \pm \\
\mathbf{1 . 0} \text { to } 6.4 \pm \mathbf{0 . 6}\end{array}$ & & $\begin{array}{c}\text { Palacios et al. } \\
\text { (2016) }\end{array}$ \\
\hline $\begin{array}{c}\text { Peñón } \\
\text { Colorado/ } \\
\text { Lanjarón } \\
\end{array}$ & $\begin{array}{l}37^{\circ} 11^{\prime} 56^{\prime \prime N} \\
3^{\circ} 24^{\prime} 23^{\prime \prime W}\end{array}$ & $\begin{array}{l}3113-2950 \\
\quad(163)\end{array}$ & 600 & $\mathrm{E}$ & $\begin{array}{c}13.0 \pm 1.1 \\
(n=4)\end{array}$ & $\begin{array}{l}3 \text { ridges } \\
\text { No data }\end{array}$ & & $\begin{array}{l}\text { Proto-rock } \\
\text { glacier } \\
\mathbf{1 0 . 5} \pm 0.9 \\
\end{array}$ & & $\begin{array}{c}\text { Palacios et al. } \\
\text { (2016) }\end{array}$ \\
\hline $\begin{array}{l}\text { Río Seco/ } \\
\text { Río Seco }\end{array}$ & $\begin{array}{l}37^{\circ} 2^{\prime} 55^{\prime \prime N} \\
3^{\circ} 20^{\prime} 39^{\prime \prime} \mathrm{W}\end{array}$ & $\begin{array}{l}3141-3000 \\
\quad(141)\end{array}$ & 600 & $\mathrm{E}$ & & $\begin{array}{c}\text { Bedrock } \\
11.9 \pm 1.1 \\
(\mathbf{n}=\mathbf{1})\end{array}$ & & $\begin{array}{l}\text { Proto-rock } \\
\text { glacier } \\
\mathbf{9 . 0} \pm \mathbf{0 . 8}\end{array}$ & & $\begin{array}{c}\text { Palacios et al. } \\
\text { (2016) }\end{array}$ \\
\hline $\begin{array}{l}\text { Caldereta/ } \\
\text { Mulhacén }\end{array}$ & $\begin{array}{c}37^{\circ} 3^{\prime} 5^{\prime \prime N} \\
3^{\circ} 19^{\prime} 32^{\prime \prime} \mathrm{W}\end{array}$ & $\begin{array}{l}3182-3000 \\
\quad(182)\end{array}$ & 900 & $\mathrm{E}$ & & $\begin{array}{c}\text { Bedrock } \\
\mathbf{1 2 . 0} \pm \mathbf{1 . 1} \\
(\mathrm{n}=\mathbf{2}) \\
\end{array}$ & & $\begin{array}{c}\text { Rock glacier } \\
\text { from } 13.1 \pm \mathbf{1 . 2} \\
\text { to } 6.3 \pm \mathbf{0 . 5} \\
\end{array}$ & & $\begin{array}{c}\text { Palacios et al. } \\
\text { (2016) }\end{array}$ \\
\hline $\begin{array}{l}\text { Corral del } \\
\text { Veleta/ } \\
\text { Guarmón }\end{array}$ & $\begin{array}{l}37^{\circ} 33^{\prime} 35^{\prime \prime N} \\
3^{\circ} 21^{\prime} 57^{\prime \prime} \mathrm{W}\end{array}$ & $\begin{array}{l}3396-3000 \\
\quad(396)\end{array}$ & 500 & $\mathrm{~N}$ & No data & $\begin{array}{c}\text { Large } \\
\text { poligenic ridge }\end{array}$ & & $\begin{array}{l}\text { Rock glacier } \\
\text { from } 1950 \mathrm{CE}\end{array}$ & $\begin{array}{l}\text { Poligenic } \\
\text { LIA ridge } \\
\text { From } 1355 \\
\text { to } 1900 \mathrm{CE} \\
\end{array}$ & $\begin{array}{c}\text { Palacios et al. } \\
\text { (2019) }\end{array}$ \\
\hline
\end{tabular}




\begin{tabular}{|c|c|c|c|c|c|c|c|c|c|}
\hline $\begin{array}{l}\text { Mulhacén } \\
\text { cirque }\end{array}$ & $\begin{array}{l}37^{\circ} 3^{\prime} 36^{\prime \prime} \mathrm{N} \\
3^{\circ} 18^{\prime} 57^{\prime \prime} \mathrm{W}\end{array}$ & $\begin{array}{c}3479-2900 \\
(579)\end{array}$ & 950 & $\mathbf{N}$ & $\begin{array}{c}14.1 \pm 0.9 \\
(n=1)(a)\end{array}$ & $\begin{array}{c}6 \text { ridges } \\
10.0 \pm 0.7 \\
(\mathbf{n}=2)(\mathrm{a})\end{array}$ & 700 & $\begin{array}{l}\text { Protalus lobe } \\
\text { from } 1900 \mathrm{CE} \\
\text { (b) }\end{array}$ & $\begin{array}{c}\text { (a) Present work } \\
\text { (b) Serrano et al. } \\
(2018)\end{array}$ \\
\hline
\end{tabular}

${ }^{1}$ Geographic coordinates of the center point of the cirque floor.

${ }^{2}$ Maximum and minimum elevation of the cirque and elevation range.

${ }^{3}$ Cirque length. From the summit to the lower sector measured on the map. It is necessary to consider that many cirques are wider than they are long.

${ }^{4}$ Aspect. It is necessary to consider that many cirques do not coincide with the head of the valley where they are located, but rather they are housed on one of its slopes with a more appropriate orientation for the accumulation of snow.

${ }^{5}$ Deglaciatoin age of the cirque according to the CRE ages obtained from bedrock outcrops on its bottom.

${ }^{6}$ Number of moraines and their CRE age in ka or CE located into the cirque. When no moraine ages are available, the age corresponds to dated bedrock surfaces.

${ }^{8}$ Rock glaciers and protalus lobe located in the cirque and the stabilization CRE age of its front and its root, when available.

${ }^{9}$ Neoglacial landforms present in the cirque. 
Table 4. Location, main topographic characteristics, geomorphological units, and average CRE ages of the cirques studied in the rest of Iberian Peninsula (outside Sierra Nevada). All CRE ages are updated following Oliva et al. (2019).

\begin{tabular}{|c|c|c|c|c|c|c|c|c|c|}
\hline $\begin{array}{l}\text { Cirque/ } \\
\text { Valley and } \\
\text { rock type }\end{array}$ & $\begin{array}{l}\text { Massif/ } \\
\text { range }^{1}\end{array}$ & $\begin{array}{c}\text { Elevation } \\
\text { (m a.s.l.) and } \\
\text { geographic } \\
\text { coordinates }^{2}\end{array}$ & Aspect $^{3}$ & $\begin{array}{l}\text { Deglaciation } \\
\text { of the cirque } \\
\qquad(\mathrm{ka})^{4}\end{array}$ & $\begin{array}{c}\text { Youngest: } \\
\text { moraine/ } \\
\text { bedrock } \\
\text { landforms } \\
(\mathrm{ka})^{5}\end{array}$ & $\begin{array}{c}\text { Distance } \\
\text { from } \\
\text { headwall to } \\
\text { the youngest } \\
\text { moraine (m) }\end{array}$ & $\begin{array}{c}\text { Rock glacier/debris- } \\
\text { covered } \\
\text { glacier/other } \\
\text { landforms (ka) }\end{array}$ & $\begin{array}{l}\text { Neoglacial } \\
\text { landforms } \\
\quad(\mathbf{k a})^{7}\end{array}$ & References \\
\hline $\begin{array}{l}\text { Cinco } \\
\text { Lagunas/ } \\
\text { Pinar } \\
\text { (Granite) }\end{array}$ & $\begin{array}{l}\text { Sierra de Gredos/ } \\
\text { Central Range }\end{array}$ & $\begin{array}{c}2572 \\
40^{\circ} 15^{\prime} 22^{\prime \prime} \mathrm{N} \\
5^{\circ} 18^{\prime} 24^{\prime \prime} \mathrm{W}\end{array}$ & NNE & $\begin{array}{c}16.3 \pm 3.3 \\
(n=2)\end{array}$ & $\begin{array}{l}\text { Bedrock } \\
10.3 \pm 1.3 \\
(\mathbf{n}=\mathbf{3})\end{array}$ & & Protalus rampart, & - & $\begin{array}{l}\text { Palacios et al. } \\
\qquad(2011)\end{array}$ \\
\hline $\begin{array}{l}\text { Gredos } \\
\text { (Granite) }\end{array}$ & $\begin{array}{l}\text { Sierra de Gredos/ } \\
\text { Central Range }\end{array}$ & $\begin{array}{c}2591 \\
40^{\circ} 14^{\prime} 56^{\prime \prime} \mathrm{N} \\
5^{\circ} 17^{\prime} 58^{\prime \prime} \mathrm{W} \\
\end{array}$ & $\mathrm{N}$ & $\begin{array}{c}15.9 \pm 1.0 \\
(n=2)\end{array}$ & & & & - & $\begin{array}{l}\text { Palacios et al. } \\
\qquad(2012 a)\end{array}$ \\
\hline $\begin{array}{l}\text { Cuerpo de } \\
\text { Hombre } \\
\text { (Granite) }\end{array}$ & $\begin{array}{l}\text { Sierra de Gredos/ } \\
\text { Central Range }\end{array}$ & $\begin{array}{c}2399 \\
40^{\circ} 17^{\prime} 32^{\prime \prime} \mathrm{N} \\
5^{\circ} 45^{\prime} 14^{\prime \prime} \mathrm{W} \\
\end{array}$ & NW & $\begin{array}{c}15.1 \pm 1.0 \\
(n=3)\end{array}$ & $\begin{array}{c}\text { Moraine } \\
12.1 \pm 1.2 \\
(n=1) \\
\end{array}$ & 600 & Rock avalanche & - & $\begin{array}{l}\text { Carrasco et al. } \\
\qquad(2015)\end{array}$ \\
\hline $\begin{array}{l}\text { Peñalara/ } \\
\text { Lozoya } \\
\text { (Gneis) }\end{array}$ & $\begin{array}{c}\text { Sierra de } \\
\text { Guadarrama/ } \\
\text { Central Range }\end{array}$ & $\begin{array}{c}2428 \\
40^{\circ} 50^{\prime} 60^{\prime \prime} \mathrm{N} \\
3^{\circ} 58^{\prime} 1^{\prime \prime} \mathrm{W}\end{array}$ & ESE & $\begin{array}{c}15.9 \pm 1.0 \\
(n=2)\end{array}$ & $\begin{array}{c}\text { Bedrock } \\
11.7 \pm 04 \\
(n=1)\end{array}$ & & $\begin{array}{l}\text { Proto-rock glacier } \\
16.1 \pm 2.5 \\
(n=1)\end{array}$ & - & $\begin{array}{l}\text { Palacios et al. } \\
\qquad(2012 b)\end{array}$ \\
\hline $\begin{array}{l}\text { Hoyo Grande/ } \\
\text { Lozoya } \\
\text { (Gneis) }\end{array}$ & $\begin{array}{c}\text { Sierra de } \\
\text { Guadarrama/ } \\
\text { Central Range } \\
\end{array}$ & $\begin{array}{c}2209 \\
40^{\circ} 58^{\prime} 46^{\prime \prime} \mathrm{N} \\
3^{\circ} 50^{\prime} 51^{\prime \prime} \mathrm{W} \\
\end{array}$ & $\mathrm{SE}$ & $\begin{array}{c}15,6 \pm 0,6 \\
(n=2)\end{array}$ & & & & & $\begin{array}{l}\text { Carrasco et al. } \\
\qquad(2016)\end{array}$ \\
\hline $\begin{array}{l}\text { San Lorenzo/ } \\
\text { Najerilla } \\
\text { (Conglomerat } \\
\text { es) }\end{array}$ & $\begin{array}{l}\text { Sierra de la } \\
\text { Demanda/ } \\
\text { Iberian Range }\end{array}$ & $\begin{array}{c}2271 \\
42^{\circ} 14^{\prime} 33^{\prime \prime} \mathrm{N} \\
2^{\circ} 58^{\prime} 22^{\prime \prime} \mathrm{W}\end{array}$ & $\mathrm{SE}$ & $\begin{array}{c}16.1 \pm 1.0 \\
(n=2)\end{array}$ & & & $\begin{array}{l}\text { Debris-covered } \\
\text { glacier } \\
9.0 \pm 0.4(n=3)\end{array}$ & - & $\begin{array}{l}\text { Fernández- } \\
\text { Fernández et al. } \\
\text { (2017) }\end{array}$ \\
\hline $\begin{array}{c}\text { Mencilla/ } \\
\text { Arlanzón } \\
\text { (Conglomerat } \\
\text { es) }\end{array}$ & $\begin{array}{l}\text { Sierra de la } \\
\text { Demanda/ } \\
\text { Iberian Range }\end{array}$ & $\begin{array}{c}1932 \\
42^{\circ} 11^{\prime} 9^{\prime \prime} \mathrm{N} \\
3^{\circ} 18^{\prime} 44^{\prime \prime} \mathrm{W}\end{array}$ & NNE & & & & $\begin{array}{l}\text { Debris-covered } \\
\text { glacier } \\
\mathbf{6 . 5} \pm \mathbf{0 . 3}(\mathrm{n}=\mathbf{8})\end{array}$ & - & $\begin{array}{l}\text { Fernández- } \\
\text { Fernández et al. } \\
\text { (2017) }\end{array}$ \\
\hline $\begin{array}{c}\text { Peña Negra/ } \\
\text { Mayor } \\
\text { (Conglomerat } \\
\text { es) }\end{array}$ & $\begin{array}{c}\text { Sierra de la } \\
\text { Cebollera/ } \\
\text { Iberian Range }\end{array}$ & $\begin{array}{c}2023 \mathrm{~m} \\
42^{\circ} 2^{\prime} 39^{\prime \prime} \\
2^{\circ} 45^{\prime} 35^{\prime \prime} \mathrm{W}\end{array}$ & ENE & $\begin{array}{c}16.6 \pm 1.0 \\
(n=2)\end{array}$ & $\begin{array}{c}\text { Bedrock } \\
\mathbf{1 3 . 5} \pm \mathbf{1 . 0} \\
(\mathbf{n}=\mathbf{1})\end{array}$ & & $\begin{array}{l}\text { Rock glacier } \\
15.1 \pm 0.9 \\
(n=3)\end{array}$ & - & $\begin{array}{l}\text { García-Ruiz et } \\
\text { al. (2020a) }\end{array}$ \\
\hline
\end{tabular}




\begin{tabular}{|c|c|c|c|c|c|c|c|c|c|}
\hline $\begin{array}{l}\text { Monasterio } \\
\text { (Quartzites) }\end{array}$ & $\begin{array}{c}\text { Montaña } \\
\text { Central/Cantabria } \\
\text { n Mountains } \\
\end{array}$ & $\begin{array}{c}2019 \\
43^{\circ} 5^{\prime} 1 " \mathrm{~N} \\
5^{\circ} 20^{\prime} 24^{\prime \prime} \mathrm{W} \\
\end{array}$ & $\mathrm{N}$ & $\begin{array}{c}14.8 \pm 0.5 \\
(n=5)\end{array}$ & & & $\begin{array}{c}\text { Rock glacier } \\
13.7 \pm 0.5(n=5)\end{array}$ & - & $\begin{array}{c}\text { Rodríguez- } \\
\text { Rodríguez et al. } \\
(2017) \\
\end{array}$ \\
\hline $\begin{array}{c}\text { Silván } \\
\text { (Quartzites) }\end{array}$ & $\begin{array}{c}\text { Montaña } \\
\text { Central/Cantabria } \\
\text { n Mountains } \\
\end{array}$ & $\begin{array}{c}1935 \\
43^{\circ} 2^{\prime} 31^{\prime \prime} \mathrm{N} \\
5^{\circ} 21^{\prime} 14^{\prime \prime} \mathrm{W} \\
\end{array}$ & ENE & & & & $\begin{array}{c}\text { Rock glacier } \\
\mathbf{1 6 . 2} \pm \mathbf{0 . 6}(\mathrm{n}=\mathbf{5})\end{array}$ & - & $\begin{array}{c}\text { Rodríguez- } \\
\text { Rodríguez et al. } \\
(2016) \\
\end{array}$ \\
\hline $\begin{array}{l}\text { Malniu-Guils } \\
\text { cirques } \\
\text { (Granite) }\end{array}$ & $\begin{array}{c}\text { Cerdanya/ } \\
\text { Eastern Pyrenees }\end{array}$ & $\begin{array}{c}2692 \\
42^{\circ} 29^{\prime} 8^{\prime \prime} \mathrm{N} \\
1^{\circ} 47^{\prime} 31^{\prime \prime} \mathrm{E}\end{array}$ & $\mathrm{S}$ & $\begin{array}{c}14.8 \pm 2.0 \\
(n=1)\end{array}$ & & & $\begin{array}{c}\text { Rock glacier } \\
\mathbf{1 4 . 7} \pm \mathbf{1 . 6}(\mathrm{n}=\mathbf{1})\end{array}$ & - & $\begin{array}{c}\text { Andrés et al. } \\
\text { (2019) }\end{array}$ \\
\hline $\begin{array}{l}\text { Perafita/ } \\
\text { Arànser } \\
\text { (Granite) }\end{array}$ & $\begin{array}{c}\text { Cerdanya/ } \\
\text { Eastern Pyrenees }\end{array}$ & $\begin{array}{c}2761 \\
42^{\circ} 26^{\prime} 59^{\prime \prime} \mathrm{N} \\
1^{\circ} 34^{\prime} 53^{\prime \prime} \mathrm{E}\end{array}$ & $\mathrm{E}$ & $\begin{array}{c}13.7 \pm 0.5 \\
(n=1)\end{array}$ & $\begin{array}{c}\text { Moraine } \\
12.6 \pm 1.7 \\
(n=1)\end{array}$ & & $\begin{array}{c}\text { Rock glacier } \\
\text { From } 14.7 \pm 2.1 \text { to } \\
\mathbf{8 . 6} \pm \mathbf{1 . 1}\end{array}$ & - & $\begin{array}{l}\text { Andrés et al, } \\
\text { (2019) }\end{array}$ \\
\hline $\begin{array}{l}\text { Bassiès/ } \\
\text { Escale } \\
\text { (Granite) }\end{array}$ & Eastern Pyrenees & $\begin{array}{c}2763 \\
42^{\circ} 37^{\prime} 0^{\prime \prime} \mathrm{N} \\
1^{\circ} 57^{\prime} 34^{\prime \prime} \mathrm{E}\end{array}$ & $\mathrm{N}$ & $\begin{array}{c}15.8 \pm 1.7 \\
(n=2)\end{array}$ & $\begin{array}{c}\text { Moraine } \\
11.7 \pm \\
\mathbf{1 . 5 ( n = 2 )}\end{array}$ & 1200 & & - & $\begin{array}{l}\text { Crest et al. } \\
\text { (2017); } \\
\text { Tomkins et al. } \\
(2018)\end{array}$ \\
\hline $\begin{array}{l}\text { Rec de la } \\
\text { Grava/ } \\
\text { (Granite) }\end{array}$ & $\begin{array}{c}\text { Cerdanya/ } \\
\text { Eastern Pyrenees }\end{array}$ & $\begin{array}{c}2763 \\
42^{\circ} 37^{\prime} 7 " \mathrm{~N} \\
1^{\circ} 57^{\prime} 16^{\prime \prime} \mathrm{E}\end{array}$ & $\mathrm{S}$ & & $\begin{array}{l}\text { Bedrock } \\
\mathbf{1 1 . 5} \pm \mathbf{2 . 0} \\
(\mathbf{n}=\mathbf{3})\end{array}$ & 1100 & & - & $\begin{array}{l}\text { Crest et al. } \\
\text { (2017); } \\
\text { Tomkins et al. } \\
\text { (2018) }\end{array}$ \\
\hline $\begin{array}{c}\text { Picot } \\
\text { Ariège valley } \\
\text { (Granite) }\end{array}$ & Eastern Pyrenees & $\begin{array}{c}2797 \\
42^{\circ} 40^{\prime} 34^{\prime \prime} \mathrm{N} \\
1^{\circ} 28^{\prime} 55^{\prime \prime} \mathrm{E} \\
\end{array}$ & NW & $\begin{array}{c}15.5 \pm 0.7 \\
(n=4)\end{array}$ & $\begin{array}{c}\text { Bedrock } \\
8.4 \pm 0.5 \\
(n=1)\end{array}$ & & $\begin{array}{c}\text { Rock glacier } \\
\text { From } \mathbf{7 . 2} \pm \mathbf{0 . 4} \text { to } \mathbf{1 . 4} \\
\pm \mathbf{0 . 2}\end{array}$ & - & $\begin{array}{l}\text { Jomelli et al. } \\
\qquad(2020)\end{array}$ \\
\hline $\begin{array}{l}\text { Médécourbe/ } \\
\text { Ariège valley } \\
\text { (Granite) }\end{array}$ & Eastern Pyrenees & $\begin{array}{c}2914 \\
42^{\circ} 36^{\prime} 13^{\prime \prime N} \\
1^{\circ} 26^{\prime} 31^{\prime \prime} \mathrm{E}\end{array}$ & $\mathrm{N}$ & $\begin{array}{c}13.2 \pm 0.7 \\
\quad(n=2)\end{array}$ & 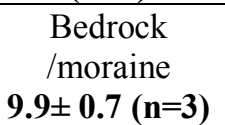 & & & - & $\begin{array}{l}\text { Jomelli et al. } \\
\qquad(2020)\end{array}$ \\
\hline $\begin{array}{l}\text { Mulleres* } \\
\text { /Noguera } \\
\text { Ribagorçana } \\
\text { (Granite) }\end{array}$ & Central Pyrenees & $\begin{array}{c}3010 \\
42^{\circ} 37^{\prime} 44^{\prime \prime} \mathrm{N} \\
0^{\circ} 41^{\prime} 54^{\prime \prime} \mathrm{E}\end{array}$ & $\mathrm{E}$ & $\begin{array}{c}13.7 \pm 0.9 \\
(n=3)\end{array}$ & $\begin{array}{c}\text { Moraine } \\
10.3 \pm 0.3 \\
(\mathbf{n}=\mathbf{2})\end{array}$ & & & - & $\begin{array}{l}\text { Pallàs et al. } \\
\text { (2006) }\end{array}$ \\
\hline $\begin{array}{c}\text { Bessiberri* } \\
\text { /Noguera } \\
\text { Ribagorçana } \\
\text { (Granite) }\end{array}$ & Central Pyrenees & $\begin{array}{c}3017 \\
42^{\circ} 35^{\prime} 41^{\prime \prime N} \\
0^{\circ} 49^{\prime} 13^{\prime \prime} \mathrm{E}\end{array}$ & $\mathrm{W}$ & $\begin{array}{c}16.3 \pm 2.2 \\
(n=1)\end{array}$ & $\begin{array}{c}\text { Moraine } \\
10.1 \pm 0.2 \\
(n=2)\end{array}$ & & & $\begin{array}{l}\text { Rock glacier } \\
\quad \text { (active) }\end{array}$ & $\begin{array}{l}\text { Pallàs et al. } \\
\text { (2006) }\end{array}$ \\
\hline
\end{tabular}




\begin{tabular}{|c|c|c|c|c|c|c|c|c|c|}
\hline $\begin{array}{l}\text { Maladeta/ } \\
\text { Esera } \\
\text { (Granite) }\end{array}$ & Central Pyrenees & $\begin{array}{c}3323 \\
42^{\circ} 38^{\prime} 47^{\prime \prime} \mathrm{N} \\
0^{\circ} 38^{\prime} 25^{\prime \prime} \mathrm{E}\end{array}$ & $\mathrm{N}$ & $\begin{array}{c}13.7 \pm 1.4 \\
(n=2)\end{array}$ & $\begin{array}{c}\text { Bedrock } \\
\text { /moraine } \\
\mathbf{1 1 . 8 \pm 1 . 1} \\
(\mathbf{n}=\mathbf{2})\end{array}$ & 1200 & & $\begin{array}{c}\text { From } 4.5 \text { to } \\
\text { LIA } \\
\text { moraine }\end{array}$ & $\begin{array}{c}\text { Crest et al. } \\
\text { (2017); } \\
\text { Tomkins et al. } \\
(2018)\end{array}$ \\
\hline $\begin{array}{c}\text { Marboré/ } \\
\text { Pineta } \\
\text { (Sandstones) }\end{array}$ & Central Pyrenees & $\begin{array}{c}3348 \\
42^{\circ} 40^{\prime} 32^{\prime \prime} \mathrm{N} \\
0^{\circ} 2^{\prime} 4 \mathrm{E}\end{array}$ & $\mathrm{N}$ & & & & & $\begin{array}{c}5.6 \pm 0.6 \\
3.6 \pm 0.4 \\
1.1 \pm 0.1 \text { and } \\
\text { LIA } \\
\text { moraines }\end{array}$ & $\begin{array}{l}\text { García-Ruiz et } \\
\text { al. (2014) }\end{array}$ \\
\hline $\begin{array}{c}\text { Arrémoulit/ } \\
\text { Osseau } \\
\text { (Granite) }\end{array}$ & Central Pyrenees & $\begin{array}{c}2821 \\
42^{\circ} 50^{\prime} 5^{\prime \prime} \mathrm{N} \\
0^{\circ} 19^{\prime} 51^{\prime \prime} \mathrm{W}\end{array}$ & $\mathrm{N}$ & & $\begin{array}{c}\text { Bedrock } \\
10.2 \pm 0.9 \\
(\mathbf{n}=\mathbf{2})\end{array}$ & & & - & $\begin{array}{l}\text { Palacios et al. } \\
\text { (2017a) }\end{array}$ \\
\hline $\begin{array}{l}\text { Balaitus/ } \\
\text { Aguas } \\
\text { Limpias } \\
\text { (Granite) }\end{array}$ & Central Pyrenees & $\begin{array}{c}3147 \\
42^{\circ} 50^{\prime} 20^{\prime \prime} \mathrm{N} \\
0^{\circ} 17^{\prime} 25^{\prime \prime} \mathrm{W}\end{array}$ & $\mathrm{S}$ & $14.6 \pm 2.0$ & $\begin{array}{c}\text { Bedrock } \\
11.0 \pm 1.4 \\
(\mathbf{n}=\mathbf{2})\end{array}$ & & & LIA moraine & $\begin{array}{l}\text { Palacios et al. } \\
\text { (2017a) }\end{array}$ \\
\hline $\begin{array}{c}\text { Bachimaña/ } \\
\text { Caldarés } \\
\text { (Granite) }\end{array}$ & Central Pyrenees & $\begin{array}{c}2728 \\
42^{\circ} 47^{\prime} 54^{\prime \prime} \mathrm{N} \\
0^{\circ} 13^{\prime} 2^{\prime \prime} \mathrm{W} \\
\end{array}$ & $\mathrm{S}$ & $\begin{array}{c}12.9 \pm 1.5 \\
(n=3)\end{array}$ & & & & - & $\begin{array}{l}\text { Palacios et al. } \\
\qquad(2017 \mathrm{a})\end{array}$ \\
\hline $\begin{array}{l}\text { Brazato/ } \\
\text { Caldarés } \\
\text { (Granite) }\end{array}$ & Central Pyrenees & $\begin{array}{c}2722 \\
42^{\circ} 44^{\prime} 21^{\prime \prime} \mathrm{N} \\
0^{\circ} 12^{\prime} 33^{\prime \prime} \mathrm{W}\end{array}$ & NNW & $14.5 \pm 1.2$ & $\begin{array}{l}\text { Bedrock } \\
\mathbf{1 1 . 4} \pm \mathbf{0 . 8}\end{array}$ & & $\begin{array}{l}\text { Rock glacier } \\
\mathbf{6 . 1} \pm \mathbf{0 . 3}(\mathrm{n}=\mathbf{2})\end{array}$ & - & $\begin{array}{l}\text { Palacios et al. } \\
\text { (2017a) }\end{array}$ \\
\hline $\begin{array}{l}\text { Catieras/ } \\
\text { Caldarés } \\
\text { (Granite) }\end{array}$ & Central Pyrenees & $\begin{array}{c}2564 \\
42^{\circ} 43^{\prime} 4^{\prime \prime} \mathrm{N} \\
0^{\circ} 11^{\prime} 18^{\prime \prime} \mathrm{W}\end{array}$ & W & $15.9 \pm 1.6$ & $\begin{array}{l}\text { Moraine } \\
\mathbf{1 0 . 9} \pm \mathbf{1 . 2}\end{array}$ & 600 & $\begin{array}{c}\text { Rock glacier } \\
\mathbf{1 2 . 0} \pm \mathbf{1 . 3}(\mathrm{n}=\mathbf{3})\end{array}$ & - & $\begin{array}{l}\text { Palacios et al. } \\
\quad(2017 \mathrm{a})\end{array}$ \\
\hline $\begin{array}{l}\text { Piniecho/ } \\
\text { Caldarés } \\
\text { (Granite) }\end{array}$ & Central Pyrenees & $\begin{array}{c}2696 \\
42^{\circ} 43^{\prime} 43^{\prime \prime} \mathrm{N} \\
0^{\circ} 12^{\prime} 12^{\prime \prime} \mathrm{W}\end{array}$ & W & $\begin{array}{c}\mathbf{1 5 . 6} \pm \mathbf{2 . 3} \\
(\mathrm{n}=4)\end{array}$ & $\begin{array}{l}\text { Moraine } \\
12.4 \pm 1.9\end{array}$ & 500 & $\begin{array}{c}\text { Rock glacier } \\
\mathbf{1 3 . 0} \pm \mathbf{1 . 3}(\mathrm{n}=\mathbf{4})\end{array}$ & - & $\begin{array}{l}\text { Palacios et al. } \\
\text { (2017a) }\end{array}$ \\
\hline
\end{tabular}

${ }^{1}$ Name of the cirque within the mountain range.

${ }^{2}$ Elevation and geographic coordinates of the highest summit of the cirque.

${ }^{3}$ Main aspect of the cirque. 
${ }^{4} \mathrm{CRE}$ age showing the deglaciation of the cirque. Note that small glaciers may have remained at the foot of the cirque walls. All ages are related to the bedrock and/or moraines distributed at the mouth of the cirque.

${ }^{5} \mathrm{CRE}$ ages indicating the final deglaciation of the cirque. All ages correspond to bedrock or moraines located in the highest parts of the cirque.

${ }^{6} \mathrm{CRE}$ ages reporting the stabilization of the rock glacier fronts. If there are two ages, the second one corresponds to the stabilization of the roots of the rock glacier. Other debris landforms (debris-covered glacier, protalus rampart, rock avalanches, etc.) located in the cirque floor are also included, with their age of stabilization.

${ }^{7}$ Existence of landforms generated by Neoglacial advances with the available CRE ages, if existing. 
Table 5. Location, main topographic characteristics, geomorphological units, and average CRE ages of the cirques studied in the Mediterranean region (Iberian Peninsula not included). All CRE ages are updated.

\begin{tabular}{|c|c|c|c|c|c|c|c|c|c|}
\hline $\begin{array}{l}\text { Cirque/ } \\
\text { Valley }\end{array}$ & $\begin{array}{l}\text { Massif/ } \\
\text { range }^{1}\end{array}$ & $\begin{array}{c}\text { Elevation } \\
\text { (m a.s.l.) and } \\
\text { coordinates }^{2}\end{array}$ & Aspect $^{3}$ & $\begin{array}{l}\text { Deglaciation } \\
\text { of the cirque } \\
\qquad(\mathrm{ka})^{4}\end{array}$ & $\begin{array}{c}\text { Youngest } \\
\text { moraine (ka) }\end{array}$ & $\begin{array}{c}\text { Distance } \\
\text { from } \\
\text { headwall to } \\
\text { the youngest } \\
\text { moraine (m) }\end{array}$ & $\begin{array}{l}\text { Rock glacier } \\
\text { landforms } \\
\text { (ka) }^{6}\end{array}$ & $\begin{array}{c}\text { Neoglacial } \\
\text { landforms } \\
\text { (ka) }^{7}\end{array}$ & References \\
\hline $\begin{array}{l}\text { Kisbe/ } \\
\text { Sayacak }\end{array}$ & $\begin{array}{l}\text { Mt. Dedegol } \\
\text { Mts Taurus } \\
\text { Anatolia Pen. }\end{array}$ & $\begin{array}{c}2750 \\
37^{\circ} 40^{\prime} 40^{\prime \prime} \mathrm{N} \\
31^{\circ} 15^{\prime} 16^{\prime \prime} \mathrm{E} \\
\end{array}$ & $\mathrm{N}$ & & $\begin{array}{c}11.5 \pm 1.1 \\
(n=2)\end{array}$ & 2500 & & & $\begin{array}{l}\text { Köse et al. } \\
\text { (2019) }\end{array}$ \\
\hline Karagol & $\begin{array}{l}\text { Mt. Dedegol } \\
\text { Mts Taurus } \\
\text { Anatolia Pen. }\end{array}$ & $\begin{array}{c}2900 \\
37^{\circ} 38^{\prime} 35^{\prime \prime} \mathrm{N} \\
31^{\circ} 17^{\prime} 25^{\prime \prime} \mathrm{E} \\
\end{array}$ & $\mathrm{E}$ & $\begin{array}{c}15.8 \pm 1.6 \\
(n=1)\end{array}$ & $12.0 \pm 1.0$ & 1800 & & & $\begin{array}{l}\text { Köse et al. } \\
\text { (2019) }\end{array}$ \\
\hline North Çimi & $\begin{array}{l}\text { Central Taurus } \\
\text { Anatolia Pen. }\end{array}$ & $\begin{array}{c}2411 \\
36^{\circ} 57^{\prime} 21^{\prime \prime} \mathrm{N} \\
31^{\circ} 59^{\prime} 32^{\prime \prime} \mathrm{E} \\
\end{array}$ & $\mathrm{E}$ & $\begin{array}{c}13.7 \pm 0.8 \\
(n=1)\end{array}$ & $\begin{array}{c}8.1 \pm 0.9 * \\
(n=2)\end{array}$ & 1500 & & & $\begin{array}{l}\text { Sarikaya et al. } \\
(2017)^{*}\end{array}$ \\
\hline South Çimi & $\begin{array}{l}\text { Central Taurus } \\
\text { Anatolia Pen. }\end{array}$ & $\begin{array}{c}2411 \\
36^{\circ} 57^{\prime} 28^{\prime \prime} \mathrm{N} \\
31^{\circ} 58^{\prime} 55^{\prime \prime} \mathrm{E}\end{array}$ & $\mathrm{E}$ & $\begin{array}{c}14.9 \pm 1.4 \\
(n=5)\end{array}$ & $\begin{array}{c}7.3 \pm 0.6 * \\
(n=4)\end{array}$ & 2500 & & & $\begin{array}{l}\text { Sarikaya et al. } \\
(2017)^{*}\end{array}$ \\
\hline Güneycik & $\begin{array}{l}\text { Central Taurus } \\
\text { Anatolia Pen. }\end{array}$ & $\begin{array}{c}2440 \\
37^{\circ} 1^{\prime} 41 " \mathrm{~N} \\
31^{\circ} 59^{\prime} 24^{\prime \prime} \mathrm{E} \\
\end{array}$ & $\mathrm{E}$ & $\begin{array}{c}14.5 \pm 1.7 \\
(n=4)\end{array}$ & & & & $\begin{array}{c}5.9 \pm 0.5 \\
(n=4)\end{array}$ & $\begin{array}{c}\text { Sarıkaya et al. } \\
\text { (2017) }\end{array}$ \\
\hline Çündüre & $\begin{array}{l}\text { Central Taurus } \\
\text { Anatolia Pen. }\end{array}$ & $\begin{array}{c}2638 \\
36^{\circ} 58^{\prime} 40^{\prime \prime} \mathrm{N} \\
32^{\circ} 1^{\prime} 46^{\prime \prime} \mathrm{E} \\
\end{array}$ & $\mathrm{NE}$ & $\begin{array}{c}14.9 \pm 2.3 \\
(n=3)\end{array}$ & & & & & $\begin{array}{c}\text { Sarıkaya et al. } \\
\text { (2017) }\end{array}$ \\
\hline $\begin{array}{l}\text { Megala } \\
\text { Kazania }\end{array}$ & $\begin{array}{c}\text { Mount Olympus } \\
\text { Balkans }\end{array}$ & $\begin{array}{c}2918 \\
40^{\circ} 05^{\prime} 0^{\prime \prime} \mathrm{N} \\
22^{\circ} 21^{\prime} 0^{\prime \prime} \mathrm{E} \\
\end{array}$ & NNE & $\begin{array}{c}13.8 \pm 1.4 \\
(n=3)\end{array}$ & $\begin{array}{c}12.0 \pm 0.8 \\
(n=2)\end{array}$ & 800 & & & $\begin{array}{l}\text { Styllas et al. } \\
\text { (2018) }\end{array}$ \\
\hline $\begin{array}{l}\text { Throne of } \\
\text { Zeus }\end{array}$ & $\begin{array}{c}\text { Mount Olympus } \\
\text { Balkans }\end{array}$ & $\begin{array}{c}2918 \\
40^{\circ} 05^{\prime} 30 " \mathrm{~N} \\
22^{\circ} 21^{\prime} 30^{\prime \prime} \mathrm{E} \\
\end{array}$ & NNW & $\begin{array}{c}14.0 \pm 1.0 \\
(n=4)\end{array}$ & & & & $\begin{array}{c}2.5 \pm 0.3 \\
(n=4) \text { and } \\
\text { LIA } \\
\end{array}$ & $\begin{array}{l}\text { Styllas et al. } \\
\text { (2018) }\end{array}$ \\
\hline $\begin{array}{c}\text { Velez } \\
\text { Mountain }\end{array}$ & Dinaric Mts. & $\begin{array}{c}1965 \\
43^{\circ} 19^{\prime} 02^{\prime \prime} \mathrm{N} \\
18^{\circ} 2^{\prime} 6^{\prime \prime} \mathrm{E} \\
\end{array}$ & $\mathrm{N}$ & $\begin{array}{c}14.9 \pm 1.1 \\
(n=2)\end{array}$ & & & & & $\begin{array}{l}\text { Zebre et al. } \\
\text { (2019) }\end{array}$ \\
\hline
\end{tabular}




\begin{tabular}{|c|c|c|c|c|c|c|}
\hline $\begin{array}{c}\text { Irhzer } \\
\text { n'Likemt }\end{array}$ & $\begin{array}{c}\text { Akusal } \\
\text { Atlas Mts. } \\
\text { Morocco }\end{array}$ & $\begin{array}{c}3555 \\
31^{\circ} 7^{\prime} 39^{\prime \prime} \mathrm{N} \\
7^{\circ} 49^{\prime} 56^{\prime \prime} \mathrm{W} \\
\end{array}$ & $\mathrm{N}$ & $\begin{array}{c}12.9 \pm 0.7 \\
(n=2)\end{array}$ & 1200 & $\begin{array}{l}\text { Hughes et al. } \\
\text { (2018) }\end{array}$ \\
\hline Azib Mzik & $\begin{array}{c}\text { Akusal } \\
\text { Atlas Mts. } \\
\text { Morocco }\end{array}$ & $\begin{array}{c}3129 \\
31^{\circ} 63^{\prime} 53^{\prime \prime N} \\
7^{\circ} 56^{\prime} 28^{\prime \prime} \mathrm{W}\end{array}$ & $\mathrm{NE}$ & $\begin{array}{c}11.8 \pm 0.6 \\
(n=3)\end{array}$ & 800 & $\begin{array}{l}\text { Hughes et al. } \\
\text { (2018) }\end{array}$ \\
\hline
\end{tabular}

${ }^{1}$ Name of the cirque within the mountain range.

${ }^{2}$ Elevation and geographic coordinates of the highest summit of the cirque.

${ }^{3}$ Main aspect of the cirque.

${ }^{4} \mathrm{CRE}$ age showing the deglaciation of the cirque, though small glaciers may have remained at the foot of the cirque walls. All ages are related to the bedrock and/or moraines distributed at the mouth of the cirque.

${ }^{5} \mathrm{CRE}$ ages indicating the final deglaciation of the cirque. All ages correspond to bedrock or moraines located in the highest parts of the cirque.

${ }^{6} \mathrm{CRE}$ ages reporting the stabilization of the rock glacier fronts. If there are two ages, the second one corresponds to the stabilization of the roots of the rock glacier.

${ }^{7}$ Existence of landforms generated by Neoglacial advances with the available CRE ages, if existing.

* These moraines are not included in the statistical analysis of the Fig. 11, as they are considered exceptional. Ages obtained in limestone under heavy erosion. 
Table 5. Location, main topographic characteristics, geomorphological units, and CRE ages of the cirques studied in the Central European region (outside Sierra Nevada). All CRE ages are updated.

\begin{tabular}{|c|c|c|c|c|c|c|c|c|c|}
\hline $\begin{array}{l}\text { Cirque/ } \\
\text { Valley }\end{array}$ & $\begin{array}{c}\text { Massif/ } \\
\text { range }^{1}\end{array}$ & $\begin{array}{c}\text { Elevation } \\
\text { (m a.s.l.) and } \\
\text { coordinates }^{2}\end{array}$ & Aspect $^{3}$ & $\begin{array}{c}\text { Deglaciation } \\
\text { of the cirque } \\
\qquad(\mathrm{ka})^{4}\end{array}$ & $\begin{array}{c}\text { Youngest } \\
\text { moraine (ka) }\end{array}$ & $\begin{array}{c}\text { Distance } \\
\text { from } \\
\text { headwall to } \\
\text { the youngest } \\
\text { moraine (m) }\end{array}$ & $\begin{array}{l}\text { Rock glacier } \\
\text { landforms } \\
\text { (ka) }^{6}\end{array}$ & $\begin{array}{l}\text { Neoglacial } \\
\text { landforms } \\
\quad(k a)^{7}\end{array}$ & References \\
\hline North Mohoru & $\begin{array}{l}\text { Parâng Mts. } \\
\text { Romanian } \\
\text { Carpathians }\end{array}$ & $\begin{array}{c}2365 \\
45^{\circ} 20^{\prime} 27^{\prime \prime} \mathrm{N} \\
23^{\circ} 36^{\prime} 25^{\prime \prime} \mathrm{E}\end{array}$ & $\mathrm{N}$ & $\begin{array}{c}13.2 \pm 1.1 \mathrm{ka} \\
(\mathrm{n}=5)\end{array}$ & $\begin{array}{c}11.8 \pm 0.2 \mathrm{ka} \\
(\mathrm{n}=2)\end{array}$ & 500 & & & $\begin{array}{c}\text { Gheorghiu et al. } \\
\text { (2015) }\end{array}$ \\
\hline Zanoaga Mare & $\begin{array}{c}\text { Parâng Mts. } \\
\text { Romanian } \\
\text { Carpathians }\end{array}$ & $\begin{array}{c}2278 \\
45^{\circ} 21^{\prime} 4^{\prime \prime} \mathrm{N} \\
23^{\circ} 31^{\prime} 60^{\prime \prime} \mathrm{E}\end{array}$ & $\mathrm{N}$ & $\begin{array}{c}13.7 \pm 1.2 \mathrm{ka} \\
(\mathrm{n}=4)\end{array}$ & $\begin{array}{c}11.0 \pm 0.9 \mathrm{ka} \\
(\mathrm{n}=2)\end{array}$ & 800 & & & $\begin{array}{l}\text { Gheorghiu et al. } \\
\text { (2015) }\end{array}$ \\
\hline Galcescu & $\begin{array}{c}\text { Parâng Mts. } \\
\text { Romanian } \\
\text { Carpathians }\end{array}$ & $\begin{array}{c}2519 \\
45^{\circ} 20^{\prime} 24^{\prime \prime} \mathrm{N} \\
23^{\circ} 32^{\prime} 25^{\prime \prime} \mathrm{E}\end{array}$ & $\mathrm{N}$ & $\begin{array}{c}15.2 \pm 1.3 \\
(n=1)\end{array}$ & $\begin{array}{c}12.0 \pm 1.1 \mathrm{ka} \\
(\mathrm{n}=3)\end{array}$ & 800 & & & $\begin{array}{l}\text { Gheorghiu et al. } \\
\text { (2915) }\end{array}$ \\
\hline $\begin{array}{c}\text { Spitze } \\
\text { Rumer Spitze }\end{array}$ & $\begin{array}{l}\text { Karwendel } \\
\text { Mts. } \\
\text { North Alps }\end{array}$ & $\begin{array}{c}2454 \\
47^{\circ} 19^{\prime} 13^{\prime \prime N} \\
11^{\circ} 25^{\prime} 35^{\prime \prime} \mathrm{E}\end{array}$ & $\mathrm{N}$ & & & & $\begin{array}{c}\text { From } 12.4 \pm \\
0.4 \text { to } 9.6 \pm \\
0.6 \\
(n=7)\end{array}$ & & $\begin{array}{l}\text { Moran et al. } \\
\text { (2016) }\end{array}$ \\
\hline Mandlspitze & $\begin{array}{l}\text { Karwendel } \\
\text { Mts. } \\
\text { North Alps }\end{array}$ & $\begin{array}{c}2370 \\
47^{\circ} 19^{\prime} 7^{\prime \prime} \mathrm{N} \\
11^{\circ} 24^{\prime} 25^{\prime \prime} \mathrm{E}\end{array}$ & $\mathrm{N}$ & & & & $\begin{array}{c}10.9 \pm 0.8 \\
(n=4)\end{array}$ & & $\begin{array}{l}\text { Moran et al. } \\
\text { (2016) }\end{array}$ \\
\hline Nefcerská & $\begin{array}{l}\text { High Tatra } \\
\text { Western } \\
\text { Carpathians }\end{array}$ & $\begin{array}{c}2428 \\
49^{\circ} 10^{\prime} 14^{\prime \prime} \mathrm{N} \\
20^{\circ} 17^{\prime \prime} 3 \\
\end{array}$ & $\mathrm{~N}$ & $\begin{array}{c}14.2 \pm 0.4 \\
(n=2)\end{array}$ & & & $\begin{array}{c}11.3 \pm 0.9 \\
(n=3)\end{array}$ & & $\begin{array}{l}\text { Zasadni et al. } \\
\qquad(2020)\end{array}$ \\
\hline Suchá važecká & $\begin{array}{c}\text { High Tatra } \\
\text { Western } \\
\text { Carpathians } \\
\end{array}$ & $\begin{array}{c}2350 \\
49^{\circ} 9^{\prime} 47^{\prime \prime} \mathrm{N} \\
20^{\circ} 0^{\prime} 48^{\prime \prime} \mathrm{E} \\
\end{array}$ & $\mathrm{S}$ & $\begin{array}{c}14.9 \pm 1.4 \\
(n=2)\end{array}$ & & & $\begin{array}{c}10.9 \pm 1.0 \\
(n=3)\end{array}$ & & $\begin{array}{c}\text { Zasadni et al. } \\
\text { (2020) }\end{array}$ \\
\hline Mlynická & $\begin{array}{c}\text { High Tatra } \\
\text { Western } \\
\text { Carpathians }\end{array}$ & $\begin{array}{c}2428 \\
49^{\circ} 10^{\prime} 14^{\prime \prime} \mathrm{N} \\
20^{\circ} 11^{\prime} 37^{\prime \prime} \mathrm{E} \\
\end{array}$ & $\mathrm{N}$ & & & & $\begin{array}{c}10.4 \pm 0.7 \\
(n=3)\end{array}$ & & $\begin{array}{l}\text { Zasadni et al. } \\
\qquad(2020)\end{array}$ \\
\hline Hincova & $\begin{array}{c}\text { High Tatra } \\
\text { Western } \\
\text { Carpathians }\end{array}$ & $\begin{array}{c}2438 \\
49^{\circ} 11^{\prime} 11^{\prime \prime} \mathrm{N} \\
20^{\circ} 3^{\prime} 38^{\prime \prime} \mathrm{E} \\
\end{array}$ & SE & $\begin{array}{c}14.8 \pm 0.5 \\
(n=1)\end{array}$ & & & $\begin{array}{c}11.9 \pm 0.7 \\
(n=3)\end{array}$ & & $\begin{array}{l}\text { Zasadni et al. } \\
\qquad(2020)\end{array}$ \\
\hline
\end{tabular}




\begin{tabular}{|c|c|c|c|c|c|c|c|}
\hline $\begin{array}{l}\text { Kasprowy } \\
\text { Wierch } \\
\text { Bystra }\end{array}$ & $\begin{array}{c}\text { High Tatra } \\
\text { Western } \\
\text { Carpathians }\end{array}$ & $\begin{array}{c}1987 \\
49^{\circ} 13^{\prime} 55^{\prime \prime} \mathrm{N} \\
19^{\circ} 58^{\prime} 54^{\prime \prime} \mathrm{E}\end{array}$ & $\mathrm{N}$ & $\begin{array}{c}14.4 \pm 0.9 \mathrm{ka} \\
(\mathrm{n}=4)\end{array}$ & & & $\begin{array}{c}\text { Makos et al. } \\
\text { (2018) }\end{array}$ \\
\hline Sucha Woda & $\begin{array}{c}\text { High Tatra } \\
\text { Western } \\
\text { Carpathians }\end{array}$ & $\begin{array}{c}2235 \\
49^{\circ} 13^{\prime} 6^{\prime \prime} \mathrm{N} \\
20^{\circ} 1^{\prime} 45^{\prime \prime} \mathrm{E}\end{array}$ & $\mathrm{N}$ & $\begin{array}{c}15.5 \pm 0.4 \mathrm{ka} \\
(\mathrm{n}=5)\end{array}$ & & & $\begin{array}{c}\text { Makos et al. } \\
\text { (2018) }\end{array}$ \\
\hline Biata Woda & $\begin{array}{c}\text { High Tatra } \\
\text { Western } \\
\text { Carpathians }\end{array}$ & $\begin{array}{c}2300 \\
49^{\circ} 13^{\prime} 10^{\prime \prime} \mathrm{N} \\
20^{\circ} 0^{\prime} 34^{\prime \prime} \mathrm{E}\end{array}$ & $\mathrm{N}$ & $\begin{array}{c}15.2 \pm 0.9 \mathrm{ka} \\
(\mathrm{n}=10)\end{array}$ & & & $\begin{array}{c}\text { Makos et al. } \\
\text { (2018) }\end{array}$ \\
\hline $\begin{array}{l}\text { Piec Stawow } \\
\text { Polskich valley }\end{array}$ & $\begin{array}{c}\text { High Tatra } \\
\text { Western } \\
\text { Carpathians }\end{array}$ & $\begin{array}{c}2503 \\
49^{\circ} 10^{\prime} 46^{\prime \prime} \mathrm{N} \\
20^{\circ} 5^{\prime} 16^{\prime \prime} \mathrm{E}\end{array}$ & $\mathrm{N}$ & $\begin{array}{c}15.1 \pm 0.7 \mathrm{ka} \\
(\mathrm{n}=5)\end{array}$ & $\begin{array}{c}10.9 \pm 0.6 \mathrm{ka} \\
(\mathrm{n}=5)\end{array}$ & 700 & $\begin{array}{l}\text { Makos et al. } \\
\text { (2018) }\end{array}$ \\
\hline Velká Studená & $\begin{array}{c}\text { High Tatra } \\
\text { Western } \\
\text { Carpathians }\end{array}$ & $\begin{array}{c}2383 \\
49^{\circ} 10^{\prime} 59^{\prime \prime} \mathrm{N} \\
20^{\circ} 8^{\prime} 40^{\prime \prime} \mathrm{E} \\
\end{array}$ & $\mathrm{E}$ & $\begin{array}{c}15.2 \pm 0.5 \\
\quad(n=4)\end{array}$ & & & $\begin{array}{c}\text { Engel et al. } \\
(2015)\end{array}$ \\
\hline Malá Studená & $\begin{array}{c}\text { High Tatra } \\
\text { Western } \\
\text { Carpathians }\end{array}$ & $\begin{array}{c}2627 \\
49^{\circ} 12^{\prime} 9^{\prime \prime} \mathrm{N} \\
20^{\circ} 11^{\prime} 46^{\prime \prime} \mathrm{E}\end{array}$ & $\mathrm{SE}$ & $\begin{array}{c}13.9 \pm 0.5 \\
(n=1)\end{array}$ & $\begin{array}{c}11.2 \pm 0.5 \\
(n=1)\end{array}$ & 500 & $\begin{array}{c}\text { Engel et al. } \\
(2015)\end{array}$ \\
\hline $\begin{array}{l}\text { Sněžka } \\
\text { Úpa valley }\end{array}$ & $\begin{array}{l}\text { Krkonoše } \\
\text { Mountains }\end{array}$ & $\begin{array}{c}1602 \\
50^{\circ} 44^{\prime} 10^{\prime \prime} \mathrm{N} \\
15^{\circ} 44^{\prime} 25^{\prime \prime} \mathrm{E}\end{array}$ & $\mathrm{S}$ & $\begin{array}{c}15.3 \pm 0.5 \\
\quad(n=1)\end{array}$ & & & $\begin{array}{c}\text { Engel et al. } \\
\text { (2017) }\end{array}$ \\
\hline Snowy cirque & $\begin{array}{l}\text { Krkonoše } \\
\text { Mountains }\end{array}$ & $\begin{array}{c}1509 \\
50^{\circ} 46^{\prime} 39^{\prime \prime} \mathrm{N} \\
15^{\circ} 34^{\prime} 03^{\prime \prime} \mathrm{E}\end{array}$ & NE & $\begin{array}{c}15.4 \pm 1.8 \\
(n=1)\end{array}$ & $\begin{array}{c}12.9 \pm 0.7 \\
(n=1)\end{array}$ & 400 & $\begin{array}{c}\text { Engel et al. } \\
\text { (2017) }\end{array}$ \\
\hline
\end{tabular}

${ }^{1}$ Name of the cirque within the mountain range.

${ }^{2}$ Elevation and geographic coordinates of the highest summit of the cirque.

${ }^{3}$ Main aspect of the cirque.

${ }^{4} \mathrm{CRE}$ age showing the deglaciation of the cirque, though small glaciers may have remained at the foot of the cirque walls. All ages are related to the moraines distributed at the mouth of the cirque.

${ }^{5} \mathrm{CRE}$ ages indicating the final deglaciation of the cirque. All ages correspond to moraines located in the highest parts of the cirque. 
${ }^{6} \mathrm{CRE}$ ages reporting the stabilization of the rock glacier fronts. If there are two ages, the second one corresponds to the stabilization of the roots of the rock glacier.

${ }^{7}$ Existence of landforms generated by Neoglacial advances with the available CRE ages, if existing. 
Table 7. Location, main topographic characteristics, geomorphological units, and average CRE ages of the cirques studied in the British Isles and Iceland. All CRE ages are updated.

\begin{tabular}{|c|c|c|c|c|c|c|c|c|c|}
\hline $\begin{array}{l}\text { Cirque/ } \\
\text { Valley }\end{array}$ & $\begin{array}{l}\text { Massif/ } \\
\text { Range }^{1}\end{array}$ & $\begin{array}{c}\text { Elevation } \\
\text { (m a.s.l.) and } \\
\text { coordinates }^{2}\end{array}$ & Aspect $^{3}$ & $\begin{array}{c}\text { Deglaciatio } \\
\text { n } \\
\text { of the } \\
\text { cirque } \\
(\mathrm{ka})^{4}\end{array}$ & $\begin{array}{c}\text { Youngest } \\
\text { moraine/ } \\
\text { bedrock } \\
(\mathbf{k a})^{5}\end{array}$ & $\begin{array}{c}\text { Distance from } \\
\text { headwall to the } \\
\text { youngest } \\
\text { moraine (m) }\end{array}$ & $\begin{array}{l}\text { Rock glacier } \\
\text { landforms } \\
\text { (ka) }^{6}\end{array}$ & $\begin{array}{l}\text { Neoglacial } \\
\text { landforms }\end{array}$ & References \\
\hline $\begin{array}{l}\text { Corranabinna } \\
\text { Lough }\end{array}$ & $\begin{array}{c}\text { Mayo } \\
\text { Western Ireland }\end{array}$ & $\begin{array}{c}670 \\
53^{\circ} 57^{\prime} 40^{\prime \prime} \mathrm{N} \\
9^{\circ} 41^{\prime} 15^{\prime \prime} \mathrm{W}\end{array}$ & $\mathrm{NNE}$ & $\begin{array}{c}15.4 \pm 1.1 \\
(n=4)\end{array}$ & & & & & Barth et al. (2018) \\
\hline $\begin{array}{l}\text { Glascairns } \\
\text { Hill }\end{array}$ & $\begin{array}{c}\text { Donegal } \\
\text { NW Ireland }\end{array}$ & $\begin{array}{c}580 \\
54^{\circ} 46^{\prime} 15^{\prime \prime} \mathrm{N} \\
8^{\circ} 1^{\prime} 42^{\prime \prime} \mathrm{W}\end{array}$ & $\mathrm{NE}$ & $\begin{array}{c}15.9 \pm 1.1 \\
(n=8)\end{array}$ & $\begin{array}{c}12.0 \pm 0.9 \\
(n=4)\end{array}$ & 850 & & & Barth et al. (2018) \\
\hline $\begin{array}{l}\text { Logaharry } \\
\text { Lough }\end{array}$ & $\begin{array}{c}\text { Mayo } \\
\text { Western Ireland }\end{array}$ & $\begin{array}{c}620 \\
53^{\circ} 37^{\prime} 38^{\prime \prime} \mathrm{N} \\
9^{\circ} 42^{\prime} 10^{\prime \prime} \mathrm{W}\end{array}$ & $\mathrm{NE}$ & $\begin{array}{c}14.2 \pm 1.2 \\
(n=4)\end{array}$ & & & & & Barth et al. (2018) \\
\hline $\begin{array}{l}\text { Sruhauncullin } \\
\text { more }\end{array}$ & $\begin{array}{c}\text { Mayo } \\
\text { Western Ireland }\end{array}$ & $\begin{array}{c}803 \\
53^{\circ} 38^{\prime} 29^{\prime \prime} \mathrm{N} \\
9^{\circ} 47^{\prime} 31^{\prime \prime} \mathrm{W}\end{array}$ & $\mathrm{NE}$ & & $\begin{array}{c}11.4 \pm 1.0 \\
(n=4)\end{array}$ & 950 & $\begin{array}{c}12.5 \pm 1.1 \\
(n=5)\end{array}$ & & Barth et al. (2018) \\
\hline $\begin{array}{l}\text { Keskadale/ } \\
\text { Newlands }\end{array}$ & $\begin{array}{c}\text { Derwent Fells/ } \\
\text { Lake District } \\
\text { British Isles }\end{array}$ & $\begin{array}{c}734 \\
54^{\circ} 32^{\prime} 30^{\prime \prime} \mathrm{N} \\
3^{\circ} 14^{\prime} 8^{\prime \prime} \mathrm{W} \\
\end{array}$ & $\mathrm{N}$ & & $\begin{array}{c}12.4 \pm 1.0 \\
\mathrm{ka} \\
(\mathrm{n}=2)\end{array}$ & 600 & & & $\begin{array}{l}\text { Hughes et al. } \\
\text { (2019) }\end{array}$ \\
\hline Ling Comb & $\begin{array}{c}\text { Derwent Fells/ } \\
\text { Lake District } \\
\text { British Isles }\end{array}$ & $\begin{array}{c}737 \\
54^{\circ} 31^{\prime} 52^{\prime \prime} \mathrm{N} \\
3^{\circ} 18^{\prime} 24^{\prime \prime} \mathrm{W} \\
\end{array}$ & $\mathrm{E}$ & & $\begin{array}{c}11.9 \pm 1.3 \\
\mathrm{ka} \\
(\mathrm{n}=4)\end{array}$ & 300 & & & $\begin{array}{l}\text { Hughes et al. } \\
\text { (2019) }\end{array}$ \\
\hline $\begin{array}{c}\text { Fremri- } \\
\text { Grjótárdalur } \\
\text { West }\end{array}$ & $\begin{array}{l}\text { Tröllaskagi } \\
\text { Northern } \\
\text { Iceland }\end{array}$ & $\begin{array}{c}1183 \\
65^{\circ} 42^{\prime} 47^{\prime \prime N} \\
19^{\circ} 0^{\prime} 6.32^{\prime \prime} \mathrm{W}\end{array}$ & $\mathrm{N}$ & & $\begin{array}{c}11.3 \pm 1.1 \\
(n=2)\end{array}$ & 1500 & $\begin{array}{c}10.8 \pm 1.0 \\
(n=2)\end{array}$ & $\begin{array}{l}\text { Active rock } \\
\text { glaciers }\end{array}$ & $\begin{array}{c}\text { Fernández- } \\
\text { Fernández et al. } \\
(2020)\end{array}$ \\
\hline $\begin{array}{l}\text { Fremri- } \\
\text { Grjótárdalur } \\
\text { East }\end{array}$ & $\begin{array}{l}\text { Tröllaskagi } \\
\text { Northern } \\
\text { Iceland }\end{array}$ & $\begin{array}{c}1183 \\
65^{\circ} 42^{\prime} 47 " \mathrm{~N} \\
19^{\circ} 0^{\prime} 6.32^{\prime \prime} \mathrm{W}\end{array}$ & $\mathrm{N}$ & & & & $\begin{array}{c}9.4 \pm 1.1 \\
(n=2)\end{array}$ & $\begin{array}{l}\text { Active rock } \\
\text { glaciers }\end{array}$ & $\begin{array}{c}\text { Fernández- } \\
\text { Fernández et al. } \\
(2020)\end{array}$ \\
\hline Hólajökull & $\begin{array}{l}\text { Tröllaskagi } \\
\text { Northern } \\
\text { Iceland }\end{array}$ & $\begin{array}{l}65^{\circ} 42^{\prime} 7 " \mathrm{~N} \\
18^{\circ} 57^{\prime} 2^{\prime \prime} \mathrm{W}\end{array}$ & $\mathrm{N}$ & & $\begin{array}{c}10.7 \pm 1.0 \\
(n=2)\end{array}$ & 3000 & & $\begin{array}{l}\text { Active debris } \\
\text { covered } \\
\text { glacier }\end{array}$ & $\begin{array}{c}\text { Fernández- } \\
\text { Fernández et al. } \\
(2020)\end{array}$ \\
\hline
\end{tabular}


${ }^{1}$ Name of the cirque within the mountain range.

${ }^{2}$ Elevation and geographic coordinates of the highest summit of the cirque.

${ }^{3}$ Main aspect of the cirque.

${ }^{4} \mathrm{CRE}$ age showing the deglaciation of the cirque. Note that small glaciers may have remained at the foot of the cirque walls. All ages are related to the bedrock and/or moraines distributed at the mouth of the cirque.

${ }^{5} \mathrm{CRE}$ ages indicating the final deglaciation of the cirque. All ages correspond to bedrock or moraines located in the highest parts of the cirque.

${ }^{6} \mathrm{CRE}$ ages reporting the stabilization of the rock glacier fronts. If there are two ages, the second one corresponds to the stabilization of the roots of the rock glacier.

${ }^{7}$ Existence of landforms generated by Neoglacial advances with the available CRE ages, if existing. 
Table 8. Location, main topographic characteristics, geomorphological units, and average CRE ages of the cirques studied in the Western North America. All CRE ages are updated.

\begin{tabular}{|c|c|c|c|c|c|c|c|c|c|}
\hline $\begin{array}{l}\text { Cirque/ } \\
\text { valley }\end{array}$ & $\begin{array}{c}\text { Massif/ } \\
\text { range }^{1}\end{array}$ & $\begin{array}{c}\text { Elevation } \\
\text { (m a.s.l.) and } \\
\text { coordinates }^{2}\end{array}$ & Aspect $^{3}$ & $\begin{array}{c}\text { Deglaciation } \\
\text { of the cirque } \\
\qquad(\mathrm{ka})^{4}\end{array}$ & $\begin{array}{c}\text { Youngest } \\
\text { moraine/ } \\
\text { bedrock } \\
(\mathbf{k a})^{5} \\
\end{array}$ & $\begin{array}{c}\text { Distance from } \\
\text { headwall to } \\
\text { the youngest } \\
\text { moraine (m) } \\
\end{array}$ & $\begin{array}{l}\text { Rock glacier } \\
\text { landforms } \\
\text { (ka) }^{6}\end{array}$ & $\begin{array}{l}\text { Neoglacial } \\
\text { landforms }^{7}\end{array}$ & References \\
\hline $\begin{array}{c}\text { Little } \\
\text { Anapurna/ } \\
\text { Inspiration } \\
\text { Lake }\end{array}$ & $\begin{array}{c}\text { Central } \\
\text { Cascades } \\
\text { Washington }\end{array}$ & $\begin{array}{c}2660 \\
47^{\circ} 28^{\prime} 8^{\prime \prime} \mathrm{N} \\
120^{\circ} 48^{\prime} 50^{\prime \prime} \mathrm{W}\end{array}$ & $\mathrm{NE}$ & & $\begin{array}{c}10.7 \pm 0.6 \\
(n=5)\end{array}$ & 1200 & & & $\begin{array}{l}\text { Marcott et al. } \\
\quad(2019)\end{array}$ \\
\hline $\begin{array}{l}\text { Solicitude } \\
\text { Lake }\end{array}$ & $\begin{array}{c}\text { Teton Range } \\
\text { Wyoming }\end{array}$ & $\begin{array}{c}3209 \\
43^{\circ} 48^{\prime} 14^{\prime \prime} \mathrm{N} \\
110^{\circ} 50^{\prime} 52^{\prime \prime} \mathrm{W}\end{array}$ & $\mathrm{E}$ & & $\begin{array}{c}12.8 \pm 0.4 \\
(n=3)\end{array}$ & 1300 & & & $\begin{array}{l}\text { Licciardi et al. } \\
\text { (2008); } \\
\text { Marcott et al. } \\
\text { (2019) }\end{array}$ \\
\hline $\begin{array}{l}\text { Roaring } \\
\text { Fork } \\
\text { Stough } \\
\text { Creek }\end{array}$ & $\begin{array}{l}\text { Wind River } \\
\text { Range } \\
\text { Wyoming }\end{array}$ & $\begin{array}{c}3720 \\
42^{\circ} 38^{\prime} 2^{\prime \prime} \mathrm{N} \\
109^{\circ} 19^{\prime \prime} \mathrm{W}\end{array}$ & $\mathrm{NE}$ & & $\begin{array}{c}12.8 \pm 0.7 \\
(n=4)\end{array}$ & 700 & $\begin{array}{l}\text { Proto-rock } \\
\text { glacier } \\
9.6 \pm 0.5 \\
(n=7)\end{array}$ & $\begin{array}{l}\text { Active rock } \\
\text { glacier }\end{array}$ & $\begin{array}{l}\text { Marcott et al. } \\
\quad(2019)\end{array}$ \\
\hline Temple lake & $\begin{array}{l}\text { Wind River } \\
\text { Range } \\
\text { Wyoming }\end{array}$ & $\begin{array}{c}3953 \\
42^{\circ} 41^{\prime} 55^{\prime \prime} \mathrm{N} \\
109^{\circ} 10^{\prime} 15^{\prime \prime} \mathrm{O}\end{array}$ & NW & $\begin{array}{c}14.0 \pm 1.0 \\
(n=7)\end{array}$ & & & & & $\begin{array}{l}\text { Marcott et al. } \\
\quad(2019)\end{array}$ \\
\hline $\begin{array}{l}\text { Medicine } \\
\text { Bow }\end{array}$ & $\begin{array}{l}\text { Rocky Mts, } \\
\text { Wyoming }\end{array}$ & $\begin{array}{c}3580 \\
41^{\circ} 20^{\prime} 36^{\prime \prime} \mathrm{N} 106^{\circ} \\
19^{\prime} 51^{\prime \prime} \mathrm{W}\end{array}$ & $\mathrm{E}$ & $\begin{array}{c}14.5 \pm 0.7 \\
(n=6)\end{array}$ & $\begin{array}{c}11.5 \pm 0.7 \\
(n=6)\end{array}$ & 600 & $\begin{array}{c}\text { Proto-rock } \\
\text { glacier } \\
10.5 \pm 0.6 \\
(\mathbf{n}=6)\end{array}$ & & $\begin{array}{l}\text { Marcott et al. } \\
\quad(2019)\end{array}$ \\
\hline $\begin{array}{l}\text { Agassiz/ } \\
\text { Blue Lake }\end{array}$ & $\begin{array}{l}\text { Uinta Mts., } \\
\text { Utah }\end{array}$ & $\begin{array}{c}3788 \\
40^{\circ} 42^{\prime} 39^{\prime \prime} \mathrm{N} \\
110^{\circ} 49^{\prime} 30^{\prime \prime} \mathrm{W} \\
\end{array}$ & $\mathrm{E}$ & $\begin{array}{c}14.4 \pm 0.7 \\
(n=6)\end{array}$ & & & & & $\begin{array}{l}\text { Marcott et al. } \\
\quad(2019)\end{array}$ \\
\hline $\begin{array}{c}\text { Dead Horse } \\
\text { Lake }\end{array}$ & $\begin{array}{l}\text { Uinta Mts., } \\
\text { Utah }\end{array}$ & $\begin{array}{c}3650 \\
40^{\circ} 44^{\prime} 24^{\prime \prime} \mathrm{N} \\
110^{\circ} 40^{\prime} 48^{\prime \prime} \mathrm{W}\end{array}$ & $\mathrm{NE}$ & $\begin{array}{c}13.4 \pm 0.7 \\
(n=6)\end{array}$ & $\begin{array}{c}11.8 \pm 0.6 \\
(n=6)\end{array}$ & 600 & $\begin{array}{l}\text { Proto-rock } \\
\text { glacier } \\
10.5 \pm 0.5 \\
(n=6)\end{array}$ & & $\begin{array}{l}\text { Marcott et al. } \\
\quad(2019)\end{array}$ \\
\hline $\begin{array}{l}\text { Arapahoe } \\
\text { Cirque }\end{array}$ & $\begin{array}{l}\text { Colorado } \\
\text { Front Range }\end{array}$ & $\begin{array}{c}4115 \\
40^{\circ} 01^{\prime} 35^{\prime \prime} \mathrm{N} \\
105^{\circ} 39^{\prime} 01^{\prime \prime} \mathrm{W}\end{array}$ & $\mathrm{E}$ & & $\begin{array}{c}11.6 \pm 0.5 \\
(n=6)\end{array}$ & 1800 & $\begin{array}{c}\text { Inner moraine } \\
10.0 \pm 0.6 \\
(n=6)\end{array}$ & & $\begin{array}{l}\text { Marcott et al. } \\
\quad(2019)\end{array}$ \\
\hline
\end{tabular}




\begin{tabular}{|c|c|c|c|c|c|c|c|c|}
\hline $\begin{array}{c}\text { Warren Mt. } \\
\text { Chicago } \\
\text { lakes }\end{array}$ & $\begin{array}{l}\text { Colorado } \\
\text { Front Range }\end{array}$ & $\begin{array}{c}4055 \\
39^{\circ} 36^{\prime} 19^{\prime \prime} \mathrm{N} \\
105^{\circ} 37^{\prime} 59^{\prime \prime} \mathrm{W} \\
\end{array}$ & $\mathrm{NE}$ & $\begin{array}{c}15.2 \pm 0.7 \\
(n=5)\end{array}$ & & & & $\begin{array}{c}\text { Marcott et al. } \\
\text { (2019) }\end{array}$ \\
\hline Wheeler & $\begin{array}{c}\text { South Snake } \\
\text { Range } \\
\text { Nevada }\end{array}$ & $\begin{array}{c}3982 \\
38^{\circ} 59^{\prime} 10^{\prime \prime} \mathrm{N} \\
114^{\circ} 18^{\prime} 48^{\prime \prime} \mathrm{W}\end{array}$ & $\mathrm{NE}$ & & $\begin{array}{c}12.5 \pm 1.3 \\
(n=6)\end{array}$ & 1800 & $\begin{array}{l}\text { Active rock } \\
\text { glacier }\end{array}$ & $\begin{array}{l}\text { Marcott et al. } \\
\text { (2019) }\end{array}$ \\
\hline $\begin{array}{c}\text { Mount } \\
\text { Thompson } \\
\text { Boon lakes } \\
\end{array}$ & $\begin{array}{l}\text { Sierra Nevada } \\
\text { California }\end{array}$ & $\begin{array}{c}4112 \\
37^{\circ} 8^{\prime} 35^{\prime \prime} \mathrm{N} \\
118^{\circ} 36^{\prime} 48^{\prime \prime} \mathrm{W} \\
\end{array}$ & $\mathrm{N}$ & & $\begin{array}{c}12.5 \pm 0.8 \\
(n=5)\end{array}$ & 2800 & & $\begin{array}{c}\text { Marcott et al. } \\
\text { (2019) }\end{array}$ \\
\hline $\begin{array}{l}\text { Badly/ } \\
\text { Katherine }\end{array}$ & $\begin{array}{c}\text { Sangre de } \\
\text { Cristo Mts, } \\
\text { New Mexico. }\end{array}$ & $\begin{array}{c}3840 \\
35^{\circ} 49^{\prime} 57^{\prime \prime} \mathrm{N} 105^{\circ} \\
45^{\prime} 28^{\prime \prime} \mathrm{W}\end{array}$ & $\mathrm{SE}$ & $\begin{array}{c}15.1 \pm 0.8 \\
(n=10)\end{array}$ & & & & $\begin{array}{c}\text { Marcott et al. } \\
(2019)\end{array}$ \\
\hline
\end{tabular}

${ }^{1}$ Name of the cirque within the mountain range.

${ }^{2}$ Elevation and geographic coordinates of the highest summit of the cirque.

${ }^{3}$ Main aspect of the cirque.

${ }^{4} \mathrm{CRE}$ age showing the deglaciation of the cirque. Note that small glaciers may have remained at the foot of the cirque walls. All ages are related to the bedrock and/or moraines distributed at the mouth of the cirque.

${ }^{5} \mathrm{CRE}$ ages indicating the final deglaciation of the cirque. All ages correspond to bedrock or moraines located in the highest parts of the cirque.

${ }^{6} \mathrm{CRE}$ ages reporting the stabilization of the rock glacier fronts. If there are two ages, the second one corresponds to the stabilization of the roots of the rock glacier.

${ }^{7}$ Existence of landforms generated by Neoglacial advances with, if existing, the available CRE ages. 